\title{
An annotated type catalogue of the geckos and pygopods (Squamata: Gekkota: Carphodactylidae, Diplodactylidae, Gekkonidae, Pygopodidae) in the collection of the Western Australian Museum
}

\author{
Ryan J. Ellis ${ }^{1, *}$, Paul Doughty' and Aaron M. Bauer ${ }^{2}$ \\ ${ }^{1}$ Department of Terrestrial Zoology, Western Australian Museum, 49 Kew Street, Welshpool, \\ Western Australia 6106, Australia. \\ 2 Department of Biology, Villanova University, 800 Lancaster Ave, Villanova, Pennsylvania 19085, U.S.A. \\ * Corresponding author: ryan.ellis@museum.wa.gov.au
}

\begin{abstract}
Western Australia supports a rich diversity of gecko and pygopod lizard species which continues to increase annually through on-going research. Many of these species have representative type material in the Western Australian Museum, where the collection currently includes a total of 2,174 type specimens representing 117 species or subspecies. There is currently type material in the collection representing 11 species or subspecies from the family Carphodactylidae (105 specimens), 44 species or subspecies from the Diplodactylidae (998 specimens), 35 species or subspecies from the Gekkonidae (791 specimens) and 27 species or subspecies from the Pygopodidae (280 specimens). The collection currently contains a total of 102 holotypes, 1 lectotype, 4 neotypes and 2,066 paratypes. An annotated catalogue is provided for all gekkonid type material currently and previously maintained in the herpetological collection of the Western Australian Museum.
\end{abstract}

KEYWORDS: type specimens, gecko, legless lizard, pygopod, nomenclature, Western Australian Museum, holotype, lectotype, neotype, paratype, allotype, cotype

\section{INTRODUCTION}

Since its establishment in 1891, the Western Australian Museum (WAM) has amassed a substantial and expansive natural history collection, particularly with respect to the terrestrial vertebrate fauna. The WAM herpetological collection represents the second largest collection in Australia, behind the Australian Museum, Sydney (AMS), and one of the largest regional collections in the world containing over 176,000 specimens, of predominantly Western Australian taxa. From the inauguration of the WAM through 1912, all material, including amphibian and reptile specimens, were accessioned into a series of six general catalogues. The earliest documented gekkotan entry into the first hardcopy WAM 'Register 1896-1900' was '1 Pygopus lepidopus [Pygopus lepidopodus]' from 'Perth', given to the museum by 'B.A. Woodward' and dated 30 August 1896. Prior to this, many entries list only 'lizard' and provide no further information. Many earlier acquisitions by the WAM were also published in local press prior to the use of formal registrations. The earliest record of a gekkotan specimen acquisition in the local press was published 17 November 1896 and listed as 'sheltopusik snake (pygopus lepidopus)' (Anonymous 1896); however, it is not known if these two records are associated with the same specimens. The whereabouts of the Pygopus lepidopodus specimen listed in the 1896-1900 register is unknown as no registration number or additional specimen information was provided that indicates whether the specimen was disposed of or maintained in the collection and later reregistered into the dedicated herpetology collection. In 1912 a separate handwritten hardcopy catalogue was established specifically for herpetological specimens and all specimens accessioned into the collection from this point forward were given a registration number prefixed with ' $R$ ' for reptile. The ' $R$ ' prefix is still in use to denote registration numbers and specimens in the herpetological collection, including amphibians. Many specimens from the earlier general hardcopy catalogues were re-catalogued into the newer herpetofauna catalogue and given ' $R$ ' numbers; however, it is not clear if this was completed for the entire collection. The earliest gekkotan specimen documented in the WAM herpetofauna catalogue is an Underwoodisaurus milii, family Carphodactylidae 
(originally entered as Gymnodactylus miliusii) from 'the Goldfields', R13, collection date not specified, accessioned 17 July 1912. All specimens formerly registered in the WAM herpetofauna catalogue with ' $R$ ' prefixed registration numbers have since been entered into the current electronic database of herpetological specimens. All new specimens are now entered directly into the electronic herpetological collection database.

As of June 2018, the WAM collection contained approximately 39,408 gekkotan specimens $(2,743$ Carphodactylidae, 11,887 Diplodactylidae, 19,362 Gekkonidae and 5,416 Pygopodidae) representing 212 species and/or subspecies including 37,793 of Australian origin and 1,615 specimens not from Australia. Extralimital specimens include Indonesia ( $\mathrm{N}$ $=1,552)$, Malaysia $(\mathrm{N}=26)$, Papua New Guinea $(\mathrm{N}=$ 11), India $(\mathrm{N}=8)$, New Caledonia $(\mathrm{N}=3)$, Singapore ( $\mathrm{N}$ $=3$, Solomon Islands $(\mathrm{N}=3)$, China $(\mathrm{N}=1)$, a single specimen with only 'Africa' presented as locality and 7 with unknown country of origin. The majority of gekkotan specimens are whole specimens fixed in a $10 \%$ formalin solution and stored in a 70\% ethanol solution. In addition, there are a small quantity of alizarinalcian stained, skeletal and skin preparations of some species. Many non-native species have been obtained via quarantine intercepts and lack precise locality data. Over 7,500 type specimens are currently or have previously been held in the WAM herpetology collection with 2,216 specimens representing types of 117 gekkonid species or subspecies: 107 primary types (102 holotypes, 1 lectotype and 4 neotypes) and 2,109 secondary types (including one designated as an allotype in the original description). A total of 42 paratype specimens have been gifted to other institutions since their designation as type material or could not be located in the collection and are considered lost. The WAM collection contains type material for 110 of the 144 currently recognised species or subspecies occurring in Western Australia (9 of the 12 Carphodactylidae, 43 of the 59 Diplodactylidae, 33 of the 48 Gekkonidae and 25 of the 33 Pygopodidae).

The taxonomic interests of WAM herpetological curators and researchers from other institutions have largely been focused on geckos and pygopods throughout the history of the collection. Prior to this, until around the mid-19th century, most taxonomic work on Western Australian gekkotans was carried out by researchers based in Europe. The result is that there are few types in the WAM from these early descriptions with the exception of some neotype designations from the WAM collection. Early taxonomic work on Western Australian gekkotans prior to the 21st century was largely facilitated by Glen M. Storr and Arnold G. Kluge, who between them described a total of 47 species or subspecies. Storr alone was responsible for the description of 26 species or subspecies of geckos and a further seven pygopods whereas Kluge was responsible for six geckos and eight pygopods.
From 2000 to present, the work of Paul Doughty, Paul M. Oliver, Mitzy Pepper, Aaron M. Bauer, J. Scott Keogh, Craig C. Moritz, Brad Maryan and their colleagues have increased Western Australian gekkotan diversity through numerous discoveries and revisionary works. Most of the new descriptions have resulted from revisions, usually with a significant molecular genetic component. Indeed, many such projects were initiated as phylogeographic studies, but uncovered cryptic species diversity (pers. obs.). These include divisions of species complexes for which distinctive morphotypes had masked subtle differences among species; examples of these kinds of species complexes include Gehyra spp. (nana, punctata and variegata), Rhynchoedura ornata, Oedura marmorata, Diplodactylus spp. (conspicillatus and vittatus) and Crenadactylus spp. In contrast to revisionary work that usually involves many specimens over a wide area, new discoveries of species have occurred. Recent biodiversity surveys of Western Australia, especially in the remote Pilbara and Kimberley regions, have revealed heretofore unsuspected distinctive new species, such as Underwoodisaurus seorsus and Heteronotia atra from the Pilbara, and Oedura murrumanu, Gehyra girloorloo and Cyrtodactylus kimberleyensis from the Kimberley.

The WAM published a list of types compiled by G.M. Storr annually in the WAM Annual Report from 1960 to 1969 (Anonymous 1961, 1970). The Annual Report type lists presented only primary type material; holotypes and lectotypes, and occasionally syntypes and neotypes were listed, but no secondary types. A total of 10 parts of the type list were presented, of which only part 2 (1960-61), part 4 (1962-63), part 5 (1963-64), part $7(1965-66)$ and part 9 (1967-68) included gekkotan material for 18 species or subspecies (Anonymous 1961, 1963, 1964, 1966, 1968). Since the 1970 Annual Report, there have been no further publications on the type material held in the herpetological collection of the WAM. Bauer and Henle (1994) presented information on all primary type specimens known to them at the time, including many Australian species with type material in the WAM collection.

In accordance with recommendation $72 \mathrm{~F}$ of the Code (ICZN 1999), a type specimen audit was initiated in order to publish a current type catalogue of the material held in the WAM herpetological collection. Due to the size of the herpetological type collection at the WAM, separate type audits were undertaken and the type catalogue will be presented in a series of publications. The first of the series was a type catalogue of the turtles (Chelidae) (Ellis and Georges 2015) followed by the frogs (Anura; Hylidae, Limnodynastidae and Myobatrachidae) (Ellis et al. 2017). The current type catalogue is the third of a series aimed at presenting all type material 
of amphibians and reptiles held by the WAM and presents the type gekkotans (Carphodactylidae, Diplodactylidae, Gekkonidae and Pygopodidae) held in the WAM collection.

\section{METHODS}

Information on type specimens was obtained from the original description and compared with information retrieved from accession data in early specimen registers and the current digital herpetology specimen database in addition to jar labels, personal communications and subsequent publications relating to relevant type material. All type specimens in the collection of the WAM were examined in addition to any respective label information and notations. Where specimens could not be located in the type collection, extensive searches of the general collection, accession data, original descriptions and other records were undertaken during the audit to locate missing specimens or those lacking data. This catalogue also includes type specimens of species that have, subsequent to their description, been synonymised and/or resurrected from synonymy with other taxa, or those with type material donated to the WAM since their description. This catalogue was prepared in accordance with the rules, recommendations, definitions and amendments of the International Code for Zoological Nomenclature (International Commission on Zoological Nomenclature [ICZN] 1999, 2003, 2012).

\section{FORMAT}

This catalogue follows the format of previous WAM type catalogues for the turtles (Testudines: Chelidae) and frogs (Anura: Hylidae, Limnodynastidae; Myobatrachidae) housed in the WAM collection (Ellis and Georges 2015; Ellis et al. 2017).

\section{ORIGINAL BINOMEN}

\section{Genus species subspecies Author, year}

\section{Original type species citation}

Author, year, title, journal, page(s), [page of description].

\section{Primary type (holotype/lectotype/syntypes)}

Registration number, locality (latitude/longitude), collector(s) and collection date.

\section{Secondary type(s) (paratype/s) (number of types in WAM collection)}

Registration number, locality.

\section{Current nomenclature}

Current generic and specific recognition of the species.

\section{Current status}

Current status and validity of the species, synonymies.

\section{Remarks}

Additional information provided on subjects including the history and status of types, location of additional type specimens, ambiguity in type designations and information regarding the synonymy or resurrection of a species or subspecies if necessary and available. Where genetic material of type specimens is held in the WAM collection, tissue type and storage method is provided.

Each taxon is presented by the name provided by the original author(s), followed by the author's name, and year of publication. Species and subspecies names are given in the exact format in which they were first published, some of which do not correspond with the current International Code of Zoological Nomenclature (1999). The original publication citation follows next displaying the author(s), year, title (of article or book), journal (unless otherwise), page(s) and the page on which the species or subspecies description commences in square brackets $([\mathrm{x}])$. Primary type (holotype, lectotype or neotype) information includes WAM registration number, locality, latitude and longitude (in degrees minutes seconds, where recorded to that precision or decimal degrees as provided in the original description), collector(s) name and collection date. Primary type localities shown in quotes are those presented in the original published descriptions, including errors. Primary type localities and coordinates shown in quotes are those presented in the original published descriptions. Coordinates presented in square brackets $[\mathrm{x}]$ unquoted are those that have been identified from accession data not presented in the description or subsequently determined based on locality data presented in the description. All dates are presented as day - month - year, month - year or year, as presented in the original description or relevant information sources. Secondary types (paratype/s) are displayed showing WAM registration number and locality. Specific locality (latitude and longitude) and collection details (collector and date) are not provided for secondary type specimens. Specimens marked with an asterix $\left(^{*}\right)$ are no longer held in the collection of the WAM, either due to being gifted to another institution, disposal by WAM or loss of specimen. Details of specimens no longer held in the collection are discussed further in the Remarks section of each species where information was available. Current nomenclature and status are only presented where change from the original binomen has occurred such as generic changes, specific amendments, changes to species or subspecies status and synonymy or resurrection from synonymy. Remarks include relevant information on issues and errors from original descriptions, specimens, historical remarks or subsequent publications referring to the species or specimens as well as information relating to the synonymy or resurrection of the species or 
information pertaining to lost or destroyed specimens. Where known, tissue samples for holotypes are presented with tissue type, storage method and storage location. Secondary type material with tissue samples deposited at the WAM are presented with tissue type and storage method where known. Tissue samples for type material that have been depleted are not presented. Square brackets $([\mathrm{x}])$ indicate corrections or additions of information presented in the original description or subsequent publications. The prefix $\mathrm{R}$ is used to denote registration numbers corresponding to the specimens in the herpetofauna collection of the WAM.

We have used the following acronyms and abbreviations in presenting type information in this catalogue, institution acronyms follow Sabaj Pérez (2016).

AMS Australian Museum, Sydney, NSW, Australia

AMNH American Museum of Natural History, New York, NY, U.S.A.

CCM Craig Charles Moritz Lab Collection, Research School of Biology, Australian National University, Canberra, Australia. Most specimens subsequently deposited in relevant museum collections located in state of capture (i.e. specimens collected in WA deposited in WAM collection).

E

EBU EBUEvolutionary Biology Unit, South Australian Museum, Adelaide, SA, Australia

ENE east-northeast

ESE east-southeast

FMNH Field Museum of Natural History, Zoology Department, Chicago, Illinois, U.S.A.

HS Homestead

Hwy Highway

ICZN International Commission on Zoological Nomenclature

Is Island

$\mathrm{km} \quad$ kilometres

MCZ Museum of Comparative Zoology, Harvard University, Cambridge, MA, U.S.A.

mi miles

MNHN Muséum National d'Histoire Naturelle, Paris, France

Mt Mount

$\mathrm{N} \quad$ north

NE northeast

NHMUK Natural History Museum (formerly British Museum (Natural History)), London, United Kingdom

NMV Museum Victoria (formerly National Museum of Victoria), Melbourne, Vic., Australia

NNE north-northeast

NNW north-northwest

$\begin{array}{ll}\text { NP } & \text { National Park } \\ \text { nr } & \text { near } \\ \text { NR } & \text { Nature Reserve } \\ \text { NT } & \text { Northern Territory, Australia }\end{array}$

NTM Museums and Art Galleries of the Northern Territory (formerly Northern Territory Museum of Arts and Sciences), Darwin, NT, Australia

NW northwest

OS Outstation

Qld Queensland

QM Queensland Museum, Brisbane, Qld, Australia

Rd Road

RMNH Naturalis-Nationaal Natuurhistorisch Museum (formerly Rijksmuseum van Natuurlijke Historie), Leiden, Netherlands

$\mathrm{S}$

SE southeast

SSE south-southeast

SSW south-southwest

SW southwest

SA South Australia

SAMA South Australian Museum, Adelaide, SA, Australia

SE southeast

SMF Senckenberg-Museum, Frankfurt, Germany (also referred to as Senckenberg Research Institute and Natural History Museum)

SMNS Staatliches Museum für Naturkunde, Stuttgart, Germany

SSE south-southeast

SSW south-southwest

Stn Station

SW southwest

the Code International Code of Zoological Nomenclature (edition included in citation)

UMMZ University of Michigan Museum of Zoology, Ann Arbor, MI, U.S.A.

USNM National Museum of Natural History, Smithsonian Institute (formerly United States National Museum), Washington D.C., U.S.A.

UWA Zoology Department Collection, University of Western Australia, Crawley, WA, Australia. Specimens formerly held in the collection have since been accessioned and registered into other collections (mostly WAM but also includes UMMZ) or disposed.

W west

WA Western Australia

WAM Western Australian Museum, Perth, WA, Australia

WNW west-northwest

WSW west-southwest 


\section{ACCOUNT OFTYPE SPECIMENS}

\section{SOUAMATA}

\section{Family Carphodactylidae}

\section{Gecko Dorreensis Péron, 1807}

Péron, F. (1807) Voyage de Découvertes aux Terres Australes, exécuté par ordre de Sa Majesté l'Empereur et Roi, Sur les Corvettes le Géographe, le Naturaliste, et la Goelette le Casuarina, Pendant les Années 1800, 1801, 1802, 1803 et 1804. Vol. I. Imprimerie Impéruale, Paris [118].

\section{Neotype}

R34085, 'Bernier Island, Shark Bay [in error, Dorre Is,

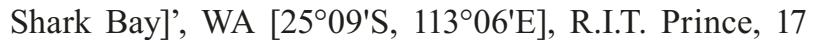
April 1969, designated by Shea (2002).

\section{Current status}

Nomen oblitum but senior subjective synonym of Phyllurus milii Bory de Saint-Vincent, 1823, fide Shea (2002).

\section{Remarks}

The species has generally been regarded as a nomen nudum (Cogger et al. 1983; Bauer 1994); however, Shea (2002) determined the name was valid for the purposes of nomenclature and designated a neotype. Despite being the senior name Shea (2002) considered Phyllurus milii Bory de Saint-Vincent, 1823 to be a nomen protectum and Gecko dorreensis a nomen oblitum in accordance with Article 23.9.1 of the 4th edition of the Code of Zoological Nomenclature (ICZN 1999) to stabilise the usage of the species epithet milii which has been consistently applied since its description.

Examination of hardcopy WAM herpetology register reveals the collection locality for the neotype specimens is Dorre Island, not Bernier Island as listed by Shea (2002).

\section{Nephrurus deleani Harvey, 1983}

Harvey, C. (1983) A new species of Nephrurus (Reptilia: Gekkonidae) from South Australia. Transactions of the Royal Society of South Australia 107: 231-235 [232].

\section{Paratype}

R80751, 44 km S Pimba, SA.

\section{Remarks}

The holotype is held in the SAMA collection, SAMA R21868 ' $44 \mathrm{~km}$ south-east of Pimba, SA $\left(31^{\circ} 31^{\prime} \mathrm{S}\right.$, $\left.137^{\circ} 08^{\prime} \mathrm{E}\right)^{\prime}$, S. Delean, 24 April 1981. Three additional paratypes are also held in the SAMA collection (SAMA R21865-67). The paratype in the WAM collection was formerly held in the SAM collection and still retains SAMA registration tag, SAMA R21864.

\section{Nephrurus levis occidentalis Storr, 1963}

Storr, G.M. (1963) The gekkonid genus Nephrurus in Western Australia, including a new species and three new subspecies. Journal of the Royal Society of Western Australia 46: 85-90 [88].

\section{Holotype}

R13918, 'Narryer, WA (26³4'S, $\left.115^{\circ} 56^{\prime} \mathrm{E}\right)$ ', N. Armstrong, 1961.

\section{Paratypes (14)}

R61, R7249, R10296, Mullewa, WA; R1904, Yuna, WA; R2255, Waggrakine, WA; R5323, Marilla, WA; R5353, Geraldton, WA; R8210, Warroora, WA; R8708, Onslow, WA; R9007, Cardabia, WA; R9165, Gnaraloo, WA; R13113, Yardie Creek, WA; R13917, Narryer, WA; R14027, North-west Cape, WA; R16864, 8 mi [12.8 km] SW Bullara, WA; R19643, Denham, WA.

\section{Remarks}

One additional paratype is mentioned by Storr with no WAM registration number; instead it lists 'A. Kluge no. 371 (7 miles [11.3 km] SSW of Learmonth)'. Kluge (1984) lists the additional paratype listed by Storr in the UMMZ reptile type list, registration number UMMZ 127159, AGK field number 371.

\section{Nephrurus levis pilbarensis Storr, 1963}

Storr, G.M. (1963) The gekkonid genus Nephrurus in Western Australia, including a new species and three new subspecies. Journal of the Royal Society of Western Australia 46: 85-90 [88].

\section{Holotype}

R14835, '12 miles [19.3 km] east of Mundabullangana, WA $\left(20^{\circ} 31^{\prime}\right.$ S, $\left.118^{\circ} 13^{\prime} E\right)$ ', G.M Storr and B.T. Clay, 23 February 1962.

\section{Paratypes (9)}

R1640, De Grey, WA; R3890, Well 15, Canning Stock Route, WA; R8520, Shaw River Tank, WA; R11330, Shaw River, WA; R13061-62, R13325, Woodstock, WA; R14833-34, Mundabullangana, WA.

\section{Nephrurus sheai Couper, 1994}

Couper, P.J. and Gregson, R.A.M. (1994) Redescription of Nephrurus asper Günther, and description of $N$. amyae sp. nov. and N. sheai sp. nov. Memoirs of the Queensland Museum 37(1): 67-81 [63].

\section{Paratypes (42)}

R1340, Leopold Downs, WA; R12614, Calwynyardah, WA; R13646, Kalumburu, WA; R26633, Halls Creek, WA; R27374, Kalumburu, WA; R43153, Mitchell Plateau, WA; R46116, Margaret River HS, WA; R46782, 
Prince Regent River [NP], WA; R47587, $8 \mathrm{~km} \mathrm{~N}$ Katherine, NT; R48175, Moola Bulla, WA; R50460, Drysdale River NP, WA; R52661, Lake Argyle, WA; R56423, King Edward River crossing, WA; R56466, Plain Creek, Beverley Springs Stn, WA; R57118, Inglis Gap, King Leopold Range, WA; R57123-27, Gibb River crossing, $47 \mathrm{~km}$ N Gibb River Stn, WA; R58636, 25 km SE Bedford Downs HS, WA; R58647, $10 \mathrm{~km} \mathrm{SE}$ Lansdowne HS, WA; R58671, 20 km ENE Tableland, WA; R60343, R60362, R60947, Jasper Gorge, 53 km NW Victoria River Downs HS, NT; R64731, 4.5 km SE Clancys Yard, WA; R70029, 43 km NW Fitzroy Crossing, WA; R70551, $9.5 \mathrm{~km}$ W Inglis Gap, WA; R70552, $8.6 \mathrm{~km} 167^{\circ}$ [SSE] Mt Amy, Napier Downs Stn, WA; R70562, 3.5 km WNW Lissadell HS, WA; R73904, Mt Barnett Stn, WA; R73903, Ellenbrae Stn, WA; R77269, R77581, R77585, Mitchell Plateau, WA; R83359, 24 km NW Mt Elizabeth HS, WA; R83531-32, Galvans Gorge, WA; R86927, Lake Argyle, WA; R87082, 0.5 km N Mary Pool, WA; R87092, 8 km SW Halls Creek, WA.

\section{Remarks}

Holotype held in the NTM collection, NTM R11470 from 'Bowerbird Camp, Magela Ck, NT (1247'S, $\left.133^{\circ} 07^{\prime} \mathrm{E}\right)^{\prime}$, collected by I. Archibald and J. Bywater, 1 September 1983. An additional 26 paratype specimens are held in other collections: 15 at NTM (NTM R267, R297, R387, R2377, R3759-61, R4027, R4272, R11464, R12493, R12605, R13485, R17822, R33718), seven at AMS (AMS R12876, R13403, R72980, R88668, R9318182, R140279), two at QM (QM J52872, J57515), one at NMV (NMV D4552) and one at SAMA (SAMA D3597) (Couper and Gregson 1994).

\section{Nephrurus stellatus Storr, 1968}

Storr, G.M. (1968) Nephrurus stellatus, a new knobtailed gecko from southern Australia. Western Australian Naturalist 10: 180-182 [180].

\section{Holotype}

R28363, '41 miles [66 km] E of Southern Cross, WA (31 $\left.25^{\circ} \mathrm{S}, 120^{\circ} 00^{\prime} \mathrm{E}\right)^{\prime}$, A. Douglas, 15 January 1967.

\section{Remarks}

One paratype specimen held in the SAMA collection (SAMA R8392) from 'near Hambidge Reserve, Eyre Peninsula, SA'.

\section{Nephrurus vertebralis Storr, 1963}

Storr, G.M. (1963) The gekkonid genus Nephrurus in Western Australia, including a new species and three new subspecies. Journal of the Royal Society of Western Australia 46: 85-90 [88].

\section{Holotype}

R5231, 'Jibberding, WA (2958'S, 116 51'E)', E.W. Pendavey, 1935.

\section{Paratypes (8)}

R1392, Bencubbin, WA; R1899, Landor, WA; R2490 [in error, R2940], Jibberding, WA; R5300, Wadgingarra, WA; R6191, Mukinbudin, WA; R13112, Yuin, WA; R13415, Kununoppin, WA; R17110, Warburton Range Mission, WA.

\section{Remarks}

One additional paratype is mentioned by Storr with no museum registration number, instead it lists 'A. Kluge no. 892 (10 miles $\mathrm{N}$ of Mundiwindi)'. This specimen is now housed in the UMMZ collection, registration number UMMZ 127160 (field no. AK 892). Kluge (1984) remarks the locality of the UMMZ specimen (127160) given by Storr 1963 is in error and the correct locality for this specimen is $4.8 \mathrm{~km} \mathrm{~S}$ Mundiwindi. One paratype registration number listed by Storr, R2490, is in error. The registration number R2490 is a specimen of Parasuta gouldii from near Quairading, WA; the correct paratype registration number is likely to be R2940, from the locality listed by Storr.

\section{Nephrurus wheeleri Loveridge, 1932}

Loveridge, A. (1932) New lizards of the genera Nephrurus and Amphibolurus from Western Australia. Proceedings of the New England Zoological Club 13: 31-34 [31].

\section{Paratype}

R4459 (formerly MCZ R32955), 'Yandil, thirty miles [48 km] northwest of Wiluna, WA' [26²2'S, 119 $49^{\circ} \mathrm{E}$ ], A.G. Paterson, September 1931.

\section{Remarks}

$\mathrm{MCZ}$ registration numbers presented by Loveridge in the description (MCZ '32,590-32,596' including that of the holotype) are in error, corrected registrations (MCZ R32950-32953) were subsequently presented by Barbour and Loveridge (1946) in the MCZ type catalogue 14 years following the description. The paratype specimen held in the WAM collection was formerly deposited in the MCZ collection, registered as MCZ R32955. The specimen was gifted by Loveridge to WAM following the species description, date unknown, and was accessioned and registered as R4459 on 30 September 1932. Barbour and Loveridge (1946) only present registration numbers for three of the six paratypes originally listed by Loveridge as the remaining three were gifted to other institutions, including WAM and another (MCZ R32954) to 'Leiden' (presumably RMNH). Although there is no record of it in the MCZ catalogue, the third gifted paratype is in the Natural History Museum, London, where it is registered as NHMUK 1946.8.23.52 (originally 1932.7.13.1, reregistered after World War II) (Patrick Campbell, personal communication, 2017). Examination of the MCZ online specimen database (http://mczbase.mcz. harvard.edu/) reveals that only six specimens (MCZ R32950-55), including the holotype, of the species were ever catalogued, suggesting that the NHMUK specimen 
may have been sent to London before it was assigned an MCZ number. Holotype held in the MCZ collection, MCZ R32950, from 'Yandil, thirty miles [48 km] northwest of Wiluna, WA', collected and presented by A.G. Paterson, September 1931.

\section{Nephrurus wheeleri cinctus Storr, 1963}

Storr, G.M. (1963) The gekkonid genus Nephrurus in Western Australia, including a new species and three new subspecies. Journal of the Royal Society of Western Australia 46: 85-90 [86].

\section{Holotype}

R4284, 'Tambrey, WA (2138'S, 117³7'E)', O. Cusack, 1931.

\section{Paratypes (18)}

R1009, Jigalong, WA; R2714-16, R4285, R5271, R8099, Tambrey, WA; R12275-76, R12283*, R1228486, Mundiwindi, WA; R13114, R14600, Mardie, WA; R13840, Roy Hill, WA; R14831-32, 14 mi [22.5 km] SW Mundiwindi, WA.

\section{Remarks}

One paratype, R12283, could not be located during the type specimen audit or documentation of gifting or loan to another institution. The presence of the specimen was not confirmed in audits undertaken in 1998 and 2008 and is considered lost.

\section{Phyllurus milii Bory de Saint-Vincent, 1823}

Bory de Saint-Vincent [J.B.G.M.] (1823). Phyllure de Milius, Phyllurus Milii, Bory. In: Audouin, [J.V.], Brongniart, A.[T.], Cambessèdes, [J.], de Candolle, [A.L.P.P.], Delafosse, G., Deshayes, [G.P.], [Loiseleur-] Deslon[g]champs, [J.L.A.], Drapiez, [P.A.J.], Edwards, [W.F.], Edwards, H.-M., Fée, A.[L.A.], Saint-Hilaire, G., Saint-Hilaire, I.G., Guérin[-Méneville], [F.E.], Guillemin, [A.], De Jussieu, A., Kunth, [C.S.], Latreille, [P.A.], Lesson, [R.P.], Prévost, [L.]C., Richard, [A.], Bory de Saint-Vincent [J.B.G.M.]. Dictionnaire classique d'Histoire naturelle. Vol. 17. Atlas et Illustration de Planches. Rey et Gravier, Paris. Plate CXX, Figure 1. [Printed and distributed as Plate IV, Figure 1 of the first livraison].

\section{Neotype}

R34085, 'Bernier Island, Shark Bay [in error, Dorre Is,

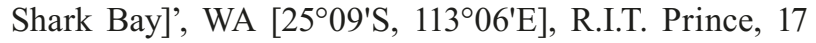
April 1969, designated by Shea (2002).

\section{Current nomenclature}

Underwoodisaurus milii, see Aplin and Smith (2001) and Oliver and Bauer (2011).

\section{Current status}

Nomen protectum over senior subjective synonym Gecko dorreensis Peron, 1807, see Shea (2002).

\section{Remarks}

Shea (2002) demonstrated the type illustration of $P$. milii was a specimen of Nephrurus levis occidentalis Storr, 1963; however, he maintained the species epithet milii for the species of Underwoodisaurus and designated a neotype in accordance with Article 23.9.1 of the 4th edition of the International Code of Zoological Nomenclature (ICZN 1999). Shea (2002) considered Phyllurus milii a nomen protecticum over the senior synonym Gecko Dorreensis to stabilise nomenclature for the species and the usage of the name milii for the species of Underwoodisaurus to which the name had been applied for over 180 years since its description (see account for Gecko Dorreensis above). Examination of hardcopy WAM herpetology register entry for the neotype specimen identifies Dorre Island as the collection locality, not Bernier Island as listed by Shea (2002).

\section{Underwoodisaurus seorsus Doughty \& Oliver, 2011}

Doughty, P. and Oliver P.M. (2011) A new species of Underwoodisaurus (Squamata: Gekkota: Carphodactylidae) from the Pilbara region of Western Australia. Zootaxa 3010: 20-30 [22].

\section{Holotype}

R157525, 'Packsaddle Range, Pilbara region, WA

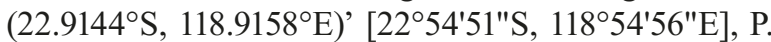
Cullen and M. Menz, 7 May 2004.

\section{Paratypes (5)}

R129895, West Angelas, 100 km NE Newman, WA; R157520, R157522, R157513, Packsaddle Range, WA; R163638, 60 km N Tom Price, WA.

\section{Remarks}

Liver samples of holotype and all paratypes stored frozen $\left(-75^{\circ} \mathrm{C}\right)$ at WAM.

\section{Family Diplodactylidae}

\section{Crenadactylus ocellatus naso Storr, 1978}

Storr, G.M. (1978a) Seven new gekkonid lizards from Western Australia. Records of the Western Australian Museum 6(3): 337-352 [337].

\section{Holotype}

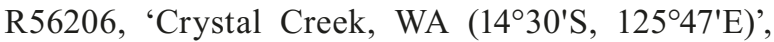
L.A. Smith and R.E. Johnstone, 2 November 1976.

\section{Paratypes (8)}

R41373-74, Heywood Is, WA; R43220-21, R43224, Mitchell Plateau, WA; R56185-87, Crystal Creek, Port Warrender, WA.

\section{Current status}

Crenadactylus naso, see Doughty et al. (2016). 


\section{Crenadactylus ocellatus rostralis Storr, 1978}

Storr, G.M. (1978a) Seven new gekkonid lizards from Western Australia. Records of the Western Australian Museum 6(3): 337-352 [339].

\section{Holotype}

R32154, 'Geikie Gorge, WA (1807'S, 125³9'E)', W.H. Butler, April 1968.

\section{Paratypes (18)}

R23058, 45 km SE Halls Creek, WA; R26824-26, Napier Range, WA; R27388-93, Mt Anderson, WA; R46058-59, nr Wolf Creek Meteorite Crater, WA; R46115, 10 km E Margaret River HS, WA; R56441-45 [in error, R56841-45], Lake Argyle, WA.

\section{Current status}

Crenadactylus rostralis, see Doughty et al. (2016).

\section{Remarks}

Five registration numbers presented by Storr are in error; the registration numbers R56441-45 are associated with specimens of other species and correct registration numbers for the specimens examined by Storr, matching the locality presented in the description and designated as type specimens, are R56841-45 (Doughty et al. 2016). Doughty et al. (2016) determined that nine paratypes (R23058, R46058-59, R46115, R56841-45) are not true $C$. rostralis and are part of the C. naso species complex.

\section{Crenadactylus occidentalis Doughty, Ellis \& Oliver, 2016}

Doughty, P., Ellis, R.J. and Oliver, P.M. (2016) Many things come in small packages: revision of the clawless geckos (Crenadactylus; Diplodactylidae) of Australia. Zootaxa 4168: 239-278 [253].

\section{Holotype}

R113683, 'Dirk Hartog Homestead, Dirk Hartog Island, WA $\left(26^{\circ} 00^{\prime} \mathrm{S}, 113^{\circ} 12^{\prime} \mathrm{E}\right)$ ', B. Maryan and R. Browne-Cooper, 19 April 1992.

\section{Paratypes (6)}

R57525, 40 km NE Yuna, WA; R96676, 10 km NW Wandina HS, WA; R120779, Nerren Nerren Stn, WA; R124891, 38 km WSW Hamelin HS, WA; R131376, 70 km S Exmouth, WA; R135497, False Entrance Well, WA.

\section{Remarks}

Liver and heart of one paratype (R124891) stored frozen $\left(-75^{\circ} \mathrm{C}\right)$ at WAM.

\section{Crenadactylus pilbarensis Doughty, Ellis \& Oliver, 2016}

Doughty, P., Ellis, R.J. and Oliver, P.M. (2016) Many things come in small packages: revision of the clawless geckos (Crenadactylus; Diplodactylidae) of Australia. Zootaxa 4168: 239-278 [259].

\section{Holotype}

R132630, 'Burrup Peninsula, WA (20³5'34"S, 116²7'58"E)’, B. Maryan, 31 May 1998.

\section{Paratypes (6)}

R100988, 80 km S Telfer, WA; R132540, R132627, R132629, Burrup Peninsula, WA; R140394, Deepdale Outstation, Robe River Stn, WA; R160059, 55 km ESE Meentheena Outcamp, WA.

\section{Remarks}

Liver sample of holotype and all paratypes stored at EBU. Heart and liver of one paratype (R132627) stored frozen $\left(-75^{\circ} \mathrm{C}\right)$ at WAM.

\section{Crenadactylus tuberculatus Doughty, Ellis \& Oliver, 2016}

Doughty, P., Ellis, R.J. and Oliver, P.M. (2016) Many things come in small packages: revision of the clawless geckos (Crenadactylus; Diplodactylidae) of Australia. Zootaxa 4168: 239-278 [256].

\section{Holotype}

R174304, 'Charles Knife Road, Cape Range National Park, North West Cape, WA $\left(22^{\circ} 05^{\prime} 26.48^{\prime} \mathrm{S}\right.$, $\left.114^{\circ} 00 ' 39.57^{\prime} E\right)^{\prime}$, P. Doughty, A.M. Bauer and R.J. Ellis, 19 August 2014.

\section{Paratypes (6)}

R61203, Yardie Creek, WA; R134295, R134627, R134945, 1.5 km SW Vlamingh Head lighthouse, North West Cape, WA; R132481, R132483, Shothole Canyon, Cape Range NP, WA.

\section{Remarks}

Liver of holotype stored in $100 \%$ ethanol solution at WAM. Liver of four paratypes (R134295, R134627, $\mathrm{R} 134945, \mathrm{R} 132481)$ and heart of one paratype (R132481) stored frozen $\left(-75^{\circ} \mathrm{C}\right)$ at WAM.

\section{Diplodactylus assimilis Storr, 1988}

Storr, G.M. (1988d) The Diplodactylus ciliaris complex (Lacertilia: Gekkonidae) in Western Australia. Records of the Western Australian Museum 14(1): 121-133 [128].

\section{Holotype}

R72164, '15 km NE Bungalbin Hill, WA (30¹8'S, 11944'E)', J. Dell, 22 April 1980.

\section{Paratypes (65)}

R1304, Laverton, WA; R14211, Cowarna Downs, WA; R15213, R48657-58, Queen Victoria Spring, WA; R15214, 17 km E Zanthus, WA; R20651, R20652-54, R56011, R60922-23, R53335, R56011, R85442-44, White Cliffs, WA; R30040, 10 km NW Kalgoorlie, WA; 
R30851-52, Karalee, WA; R49283, Mt Kenneth, WA; R53290, 10 km SW Kookynie, WA; R60922-23, Paynes Find, WA; R61322, 25 km E Yellowdine, WA; R67109, 16 km NE Bungalbin Hill, WA; R67122, R67124, R72112, 12 km NE Bungalbin Hill, WA; R67174, R72165-70, R72213, R76141, R76195, R76218-19, R76226-27, 15 km NE Bungalbin Hill, WA; R67184, 20 km NE Bungalbin Hill, WA; R69068-70, Yuinmery, WA; R72362, 18 km N Heartbreak Ridge, WA; R74502, 32 km N Heartbreak Ridge, WA; R75576, Yalgoo, WA; R76034-35, R7604447, 4 km NNE Mt Jackson, WA; R78694, 10 km ESE Mt Manning Reserve, WA; R78724, 21 km S Woolgangie, WA; R78765, R78776, Boodarding Rock, WA; R86639, 28 km S Leonora, WA; R86641, 50 km S Leonora, WA; R94595, 7 km NE Norseman, WA; R95545-46, 17 km N Jeedamya, WA; R95549-50, Comet Vale, WA.

\section{Current nomenclature}

Strophurus assimilis, see Greer (1989).

\section{Remarks}

In the original description under paratypes Storr stated 'For details of 67 specimens see under Material'; however, only 65 specimens are listed. A number of additional specimens were available to Storr at the time of description; however, there is no indication which additional two specimens were intended to be paratypes and we regard only the 65 specimens listed by Storr, excluding the holotype, as paratypes.

\section{Diplodactylus bilybara Couper, Pepper \& Oliver, 2014}

Oliver, P.M., Couper, P.J. and Pepper, M. (2014a) Independent transitions between monsoonal and arid biomes revealed by systematic revision of a complex of Australian geckos (Diplodactylus: Diplodactylidae). PLoS ONE 9(12): e111895 [41/53].

\section{Holotype}

R174500 (formerly SAMA R22820), '21 km S Barradale WA $\left(22^{\circ} 55^{\prime}\right.$ S, $\left.114^{\circ} 46^{\prime} \mathrm{E}\right)$ ', B. Miller, 1982.

\section{Paratypes (22)}

R110027, 6 km S Karratha, WA; R110058, 3.5 km S Karratha, WA; R110148, 8 km S Coolawanyah, WA; R110182, R110218, R110220, 12.5 km SW Millstream, WA; R132529, R132531, R132532, Burrup Peninsula, WA; R134523, 8 km N Exmouth, WA; R158331, R159932, Giralia HS, WA; R159892, R159894, R159940, R159947, 10 km S Mallina HS, WA; R162052-53, 21 km SSE Mt Amy, WA; R162059, 19.5 km SSW Mt Amy, WA; R163018, 7 km SSE Mt Minnie, WA; R165155, 8.5 km WSW Yanyare River mouth, WA; R165177, 9.5 km ESE Marda Pool, WA.

\section{Remarks}

The holotype was formerly registered as SAMA R22820 before being deposited at WAM following the species description in accordance with WA permit requirements. Five additional paratype specimens are held at other collections: four at SAMA (SAMA R22905, R22818-19, R22821) and one at AMS (AMS R165713). Liver sample of holotype stored at SAMA. Liver sample of all paratypes and heart of three (R132529, R132531-32) stored frozen $\left(-75^{\circ} \mathrm{C}\right)$ at WAM.

\section{Diplodactylus calcicolus Hutchinson, Doughty \& Oliver, 2009}

Hutchinson, M.N., Doughty, P. and Oliver, P.M. (2009) Taxonomic revision of the stone geckos (Squamata: Diplodactylidae: Diplodactylus) of southern Australia. Zootaxa 2167: 25-46 [37].

\section{Paratypes (22)}

R24602, Eucla, WA; R39921, 2 mi [3.2 km] W Greenshield Soak, WA; R56866, Eyre, WA; R91602, 16 km E Toolinna Rockhole, WA; R91627-28, R91630, $53 \mathrm{~km}$ WNW Toolinna Rockhole, WA; R93273, R93275, 32 km NW Clyde Hill, WA; R114154, 4 km N Ravensthorpe, WA; R116051, Calyerup Rocks, WA; R133572, Saint Ronans NR, WA; R140932, R140941, 27.5 km SSE Peak Eleanora, WA; R143815, Lake Magenta NR, WA; R144224, Bandalup Hill, WA; R149069, Scaddan area, WA; R151209, Salmon Gums area, WA; R154175, nr Kundip, WA; R156209, Kundip, WA; R156943, R156947, Forrestania area, WA.

\section{Remarks}

Holotype held in the SAMA collection, SAMA R25343, 'Hambidge Conservation Park, Eyre Peninsula, SA $\left(30^{\circ} 26^{\prime} 40^{\prime \prime} \mathrm{S}, 136^{\circ} 02^{\prime} 30^{\prime \prime E}\right)^{\prime}$, collected by the Mammal Club of the SA Field Naturalists' Society, 23 April 1984. An additional 11 paratypes held in the SAMA collection (SAMA R24763, R25382, R26257, R26322, R26495-97, R36643, R39517, R44119, R52488). Two paratypes, R24602 and R39921 are also paratypes of Diplodactylus granariensis Storr, 1979. Liver of 10 paratypes (R114154, R116051，R140932，R140941，R144224，R151209, R154175, R156209, R156943, R156947) and heart of two (R114154, R116051) stored frozen $\left(-75^{\circ} \mathrm{C}\right)$ at the WAM.

\section{Diplodactylus capensis Doughty, Oliver \& Adams, 2008}

Doughty, P., Oliver, P. and Adams, M. (2008) Systematics of stone geckos in the genus Diplodactylus (Reptilia: Diplodactylidae) from northwestern Australia, with a description of a new species from the Northwest Cape, Western Australia. Records of the Western Australian Museum 24: 247265 [259].

Holotype

R154901, 'Shothole Canyon, Northwest Cape, WA (22 $\left.{ }^{\circ} 03^{\prime} 12^{\prime \prime S}, 114^{\circ} 01^{\prime} 11^{\prime \prime E}\right)^{\prime}$, P. Doughty, 13 April 2004. 


\section{Paratypes (9)}

R81328, 6 km S Exmouth, WA; R81342, R117870, R132465-66, Shothole Canyon, WA; R102843, R102900, Cape Range NP, WA; R141700, Learmonth, WA; R154902, 9 km S Exmouth.

\section{Remarks}

Liver of the holotype stored frozen $\left(-75^{\circ} \mathrm{C}\right)$ at WAM. Liver of five paratypes (R102843, R102900, R117870, $\mathrm{R} 141700$, R154902) and heart of two paratypes (R132465-66) stored frozen $\left(-75^{\circ} \mathrm{C}\right)$ at WAM.

\section{Diplodactylus custos Couper, Oliver \& Pepper, 2014}

Oliver, P.M., Couper, P.J. and Pepper, M. (2014a) Independent transitions between monsoonal and arid biomes revealed by systematic revision of a complex of Australian geckos (Diplodactylus: Diplodactylidae). PLoS ONE 9(12): el11895 [45/53].

\section{Holotype}

R164780, 'The Grotto, WA (1543'04"S, 128¹5'35"E)', P. Doughty, P. Oliver and D. Moore, 17 January 2008.

\section{Paratypes (15)}

R11255 [in error, R11225], Wotjulum, WA; R70374, nr Lissadell HS, WA; R77417, Port Warrender, WA; R78243, Mitchell Plateau, WA; R85120-21, Kununurra, WA; R103420, R103448, Bungle Bungle NP, WA; R119666, Cockburn Range, WA; R132713, 30 km SSE Wyndham, WA; R145042, Koolan Is, WA; R162453, 20 km W Kununurra, WA; R172675, Talbot Bay, WA; R172853, Ellenbrae Stn, WA; R172916, Doongan Stn, WA.

\section{Remarks}

The paratype registration number R11255 is associated with two specimens, one a Notechis scutatus from Esperance, WA, which original registration catalogues show was the specimen first assigned the number, and a second, a specimen of $D$. custos bearing a duplicate dymo-printed registration number. The Notechis scutatus specimen associated with the registration number could not be located and is presumed lost or disposed, with no indication in specimen catalogues or the current specimen database that the registration has been reused for a specimen of D. custos. Examination of original registration catalogues shows a specimen of D. custos (originally registered as D. conspicillatus) matching the locality referred to by Oliver et al. (2014a) registered as R11225; however, no specimens bearing the registration number were located in the collection. Oliver et al. (2014a) list R11255, based on the specimen bearing a registration tag with that number, though they provide locality data for R11225 which is presumably the correct registration number associated with the specimen and the dymo-printed registration tag on the specimen is an error. One additional paratype, SAMA
R63942, is held in the SAMA collection. Liver of the holotype stored in $100 \%$ ethanol at WAM. Liver of six paratypes stored at WAM, two stored frozen $\left(-75^{\circ} \mathrm{C}\right.$; R132713, R145042) and four in 100\% ethanol solution (R162453, R172675, R172853, R172916).

\section{Diplodactylus fulleri Storr, 1978}

Storr, G.M. (1978a) Seven new gekkonid lizards from Western Australia. Records of the Western Australian Museum 6(3): 337-352 [345].

\section{Holotype}

R31331, ' $5 \mathrm{~km} \mathrm{~W}$ of the mouth of Savoury Creek

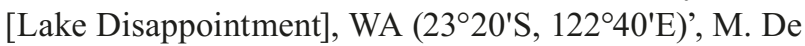
Graaf, in May 1968.

\section{Diplodactylus galaxias Doughty, Pepper \& Keogh, 2010}

Doughty, D., Pepper, M. and Keogh, J.S. (2010) Morphological and molecular assessment of the Diplodactylus savagei species complex in the Pilbara region, Western Australia, with a description of a new species. Zootaxa 2393: 33-45 [40].

\section{Holotype}

R113624, '42 km NNE Munjina Roadhouse, WA (2159'S, 11845'E)' [2154'S, $\left.118^{\circ} 50^{\prime} \mathrm{E}\right]$, B. Bush, 15 April 1992.

\section{Paratypes (7)}

R146616, 203 km S Port Hedland, WA; R158145, 24.5 km N Cowra Line Camp, WA; R165134, 2.6 km WNW Python Pool, WA; R165502, R165516, R165532, West Intercourse Is, WA; R166639, Mons Cupri Mine, WA.

\section{Remarks}

Liver and heart of holotype and liver of all paratypes stored frozen $\left(-75^{\circ} \mathrm{C}\right)$ at WAM.

\section{Diplodactylus granariensis Storr, 1979}

Storr, G.M. (1979a) The Diplodactylus vittatus complex (Lacertilia, Gekkonidae) in Western Australia. Records of the Western Australian Museum 7(4): 391-402 [397].

\section{Holotype}

R54239, 'Walyahmoning Rock, WA (20³8'S, 11843'E)’, R.B. Humphries, 10 August 1973.

\section{Paratypes (305)}

R1958, Collie, WA; R3323, Mooliabeenee, WA; R12259-60 [in error, R15259-60], Dalyup River, WA; R15245, Culham, WA; R15249, Darlington, WA; R15257-58, Jerramongup, WA; R15261-62, Coragina Rock, WA; R15263-64, R53438-43, Newman 
Rocks, WA; R15292, R34451-61, Roe Plains, 25 km ESE Cocklebiddy, WA; R15999, Seemore Downs, WA; R17867-68 Chester Pass, Stirling Range, WA; R19808-09, R28951, R29046, Lake Varley, WA; R20607, Kalgoorlie, WA; R22277, 25 km E Jurien Bay, WA; R22842-43, 25 km SW Toodyay, WA; R22849, Kojonup, WA; R23349, 10 km E Woodaniling, WA; R24601-02, Eucla, WA; R24652, Madura, WA; R24663-67, R27369, R31892，R53375-86, R53418, R54249, 8-14 km SE Cocklebiddy, WA; R25286-87, 8 km NE Mt Peron, WA; R25514, Mundrabilla, WA; R25674, 11 km N New Norcia, WA; R26005, 11 km W Darkan, WA; R26029, Forest, WA; R26384, Comet Vale, WA; R26858, Wanneroo, WA; R26859, 7 mi [11.2 km] N New Norcia, WA; R27395-96, 13 km W Bolgart, WA; R27397-99, 12 km E of mouth of Hutt River, WA; R28153, S Caiguna, WA; R29173, Loongana, WA; R29288, Boya, WA; R29472, 33 km N Balladonia Hotel, Zanthus Rd, WA; R30751-55, 13 km E Fraser Range, WA; R30789, Salmon Gums, WA; R30827-28, 8 km N Ravensthorpe, WA; R31894, 40 km W Caiguna, WA; R31948, Dryandra, WA; R33955, 48 km S Karalee, WA; R34439-41, 45 km S Madura, WA; R34485, 20 km S Madura, WA; R36008, R36787-90, R36873, R36935, R36952-53, Fitzgerald River, WA; R36435, Pigeon Rocks, WA; R37732, Point Malcom, WA; R37821, Split Rock, 30 km N Mt Holland, WA; R39842-43, R39881, R39886, R39918-19, R39920-21, Greenshields Soak, 29 km E Pingrup, WA; R39902, R43000 [in error, R45300], R43001 [in error, R45301], R43006 [in error, R45306], R43985, R45306, Lake Magenta Reserve, WA; R40060, R40084, R44423, North Tarin Rock Reserve, WA; R40230*, Lower Chittering, WA; R41180-81, R54243, Walyahmoning Rock, WA; R41194-97, 80 km NE Rawlinna, WA; R41211, R41629, 36 km NW Rawlinna, WA; R41625, 100 km NE Loongana, WA; R42616, 10 km SE Ongerup, WA; R42977, Dragon Rocks Reserve, WA; R42991, 11 km NW Dragon Rocks, WA; R43427, Bendering Reserve, WA; R43612-15, R43622-26, Buntine NR, WA; R45967-70, R46321-22, R46330, R46333, R46355-58, Trayning Reserve, 11 km E Kununoppin, WA; R46138, Billyacatting NR, $11 \mathrm{~km}$ NE Kununoppin, WA; R47624, $32 \mathrm{~km} \mathrm{NNE}$ Ravensthorpe, WA; R48056 [in error, R48656], Queen Victoria Spring, WA; R48084, R48087, R48245, R56997-98, East Yuna NR, 50 km ESE Yuna, WA; R48312-13, R48333, R48356, 48 km N Beacon, WA; R49002-03, R49015, R48021-23, 4 km E Mt Peron, WA; R49100, 5 km W Padbury, WA; R49578-81, R49585-87, R49758*, R49759, Dongolocking NR, WA; R50005-06, 5 km SW Mawson, WA; R50007, 3 km NW Beverley, WA; R50208-15, R51334-40, 25 km E Yornaning, WA; R50245, Wongan Hills, WA; R51109-10, R51112-16, 12 km NE Dalwallinu, WA; R52208-10, R52211* (now MCZ R158518), R52212* (now MCZ R158519), R52213* (now MCZ R158520), R52214* (now MCZ R158521), R52215* (now MCZ R158522), R52401-02, $21 \mathrm{~km} \mathrm{NE}$ Quairading, WA; R52316, Yorakine Rock NR, WA; R52360, 17 km NW Kellerberrin, WA; R52361, 18 km NW Kellerberrin, WA; R52565-70, 8 km NE Bendering, WA; R53345-47, 21 km E Balladonia, WA; R54240,
Chidlow, WA; R54241, 6 km SW Walyahmoning Rock, WA; R54242, 87 km N Mt Barker, WA; R54244, Ongerup, WA; R54250, York, WA; R55934, 8 km N Hopetoun, WA; R57040, 52 km NNE Bonnie Rock, WA; R57642, R57648, R57650-52, R57658-59, R57671-73, R57675-77, R57681*, R57682, R57685, Wilroy NR, 19 km S Mullewa, WA; R57775, Marchagee Reserve, WA; R57867-906, 20 km NE Dalwallinu, WA.

\section{Remarks}

Four registration numbers presented by Storr are in error: R43000 is a specimen of Ctenophorus cristatus, R43001 is a specimen of Ctenophorus scutulatus, R43006 a Ctenotus inornatus and R48056 a Ctenophorus maculatus. The correct registration numbers for R43000-01, being Diplodactylus granariensis specimens matching the localities given by Storr, are R45300-01. R45306 is likely to be the correct registration for R43006 given by Storr; however, R45306 is also listed by Storr under materials examined, with no other specimens with similar registration numbers matching the locality given by Storr. R48656 is likely to be the correct registration number for R48056 with matching locality data; however, R48656 has subsequently been identified as a specimen of Diplodactylus wiru Hutchinson, Doughty \& Oliver, 2009. Two paratypes (R24602 and R39921) are also paratypes of Diplodactylus calcicolus Hutchinson, Doughty \& Oliver, 2009.

Five paratypes were gifted to $\mathrm{MCZ}$ by Storr on 17 December 1979 (R52211-15, now MCZ R158518-22). One paratype was gifted to AMS by Storr after the description (R49758, now AMS R65114). One paratype (R57681) was not recorded in a type audit in 2008 and has not been seen since; therefore, the specimen is considered lost.

Kluge (1965) reported on examinations of the types of Phyllodactylus barbouri Angel, 1936 in the MNHN and Diplodactylus vittatus Gray, 1832 in the NHMUK, and concluded they were conspecific. This was despite the former having a putative collection location of Madagascar but owing to the morphological similarities between the types. After the description of D. granariensis in 1979, wherein Storr was unaware of the issues presented by the P. barbouri holotype, Brygoo (1991) and Bauer and Henle (1994) indicated that $P$. barbouri may be a senior synonym of $D$. granariensis rather than $D$. vittatus. The issue was not resolved in a recent revision of the $D$. vittatus speciesgroup by Hutchinson et al. (2009) as the holotype of $P$. barbouri was not examined; however, the need for further work to determine whether the holotype could be assigned to any taxa recognised in the paper was noted as all are quite similar morphologically. Photographs of the type specimen of $P$. barbouri at the MNHN (MNHN 5600), also illustrated in Angel (1942, pl. IX fig. 7), revealed morphological and pattern similarities consistent with $D$. furcosus Peters, 1863. Following this, we treat $P$. barbouri Angel, 1936 as a junior synonym of D. furcosus Peters, 1863 in this paper. 


\section{Diplodactylus granariensis rex Storr, 1988}

Storr, G.M. (1988b) Three new Diplodactylus (Lacertilia: Gekkonidae) from the arid zone of Australia. Records of the Western Australian Museum 14: 217-223 [220].

\section{Holotype}

R97288, '44 km SE Leinster, WA (28 $\left.{ }^{\circ} 13^{\prime} \mathrm{S}, 121^{\circ} 00^{\prime} \mathrm{E}\right)$ ', B.G. Bush, 4 October 1986.

\section{Paratypes (10)}

R69029-31, 24 km ESE Yuinmery, WA; R69084-86, 29 km ENE Yuinmery, WA; R73622, Ophthalmia Range, WA; R81510-11, 21 km SE Bulloo Downs, WA; R97289, 50 km SE Leinster, WA.

\section{Diplodactylus immaculatus Storr, 1988}

Storr, G.M. (1988b) Three new Diplodactylus (Lacertilia: Gekkonidae) from the arid zone of Australia. Records of the Western Australian Museum 14: 217-223 [217].

\section{Holotype}

R21408, '5 km E Tennant Creek, NT (1940'S, 134¹4'E)', S.N. Wills, 25 November 1960.

\section{Paratypes (13)}

R21409, nr Tennant Creek, NT; R21494, $10 \mathrm{~km}$ E Tennant Creek, NT; R55376, 6 km E Mt Isa, Qld; R55397, 13 km N Mt Isa, Qld; R55436-38, R55590-91, Fermoy, Qld; R74011-14, Renner Springs, NT.

\section{Current nomenclature}

Lucasium immaculatum, see Oliver et al. (2007)

\section{Diplodactylus jeanae Storr, 1988}

Storr, G.M. (1988a) A new species of Diplodactylus (Lacertilia: Gekkonidae) from northern Australia. Records of the Western Australian Museum 14: 183187 [183].

\section{Holotype}

R81843, 'Port Hedland, WA (20¹9'S, 118³6'E)', B.G. Bush, 22 November 1982.

\section{Paratypes (133)}

R2115, De Grey, WA; R15833, 27 km N Weld Spring, WA; R21384-87, 3 km SE Tennant Creek, WA; R21777-99, 25 km SW Port Hedland, WA; R24152--59, 14 km SE Elliott, NT; R25147, 3 km SE Turee Creek, WA; R26031, Christmas Creek, WA; R27402, 16 km S Lagrange, WA; R30389-91, Mundabullangana, WA; R36137, 192 km SE Wallal, WA; R36326, Port Hedland, WA; R46215, Lagrange, WA; R48942-50, R56694-98, Barrow Is, WA; R52948* (now MCZ R158544),
R52961-62, R61053, R61176-77, R61193, R61216-17, R61400, R61488, Vlaming Head, WA; R53798-800, 27 km ENE Dampier Downs, WA; R53956-57, R70938, Edgar Ranges, WA; R57263, R57310, McLarty Hills, WA; R58257, Exmouth, WA; R63315-17, R63326, R63348-49, R63360, Lens Bore, WA; R63422, Twin Heads, WA; R64025, Wolfe Creek Crater, WA; R64103, Djaluwon Creek, WA; R64245, R64252, 39 km SSW McTavish Claypan, WA; R67568, R83589-90, Balgo, WA; R69509, Anketell Ridge, WA; R69907-08, R69916-17, 26 km E Bishops Dell, WA; R73606, 25 km SW Marillana, WA; R75107, 13 km E Anna Plains, WA; R80405, 10 km NE Urala, WA; R80456, 9 km NW Barradale, WA; R83591-92, 42 km ESE Billiluna, WA; R83593, 44 km S Balgo, WA; R83731-39, 10 km S Turee Creek, WA; R85336-40, 4 km S Onslow, WA; R95444, 80 km S Telfer, WA; R95647-52, 14 km SSW Turee Creek, WA; R96978-80, Ehrenberg Range, NT; R96981, Kintore Range, NT; R96982, Willie Rockhole, NT.

\section{Current nomenclature}

Strophurus jeanae, see Greer (1989).

\section{Remarks}

Under paratypes Storr states 'for details of 131 specimens see material'; however, there are 133 registration numbers (excluding the holotype) given. It is not known if this is an error in text under paratypes or if two specimens listed were not selected as paratypes, and if so there is no indication which specimens were not meant to be designated as paratypes. All specimens listed under 'material' other than the holotype are considered as paratypes here. One paratype (R52948) was gifted to MCZ on 17 December 1979 (now, MCZ R158544).

\section{Diplodactylus kenneallyi Storr, 1988}

Storr, G. M. (1988b) Three new Diplodactylus (Lacertilia: Gekkonidae) from the arid zone of Australia. Records of the Western Australian Museum 14: $217-223$ [221].

Holotype

R95245, 'foot of stony hill near Lake Buchanan, WA (253' $\left.\mathrm{S}, 123^{\circ} 05^{\prime} \mathrm{E}\right)^{\prime}, \mathrm{R}$. Miller, 4 August 1986.

\section{Diplodactylus klugei Aplin \& Adams, 1998}

Aplin, K.P. and Adams, M. (1998) Morphological and genetic discrimination of new species and subspecies of gekkonid and scincid lizards (Squamata: Lacertilia) from the Carnarvon Basin region of Western Australia. Journal of the Royal Society of Western Australia 81: 201-223 [202]. 


\section{Holotype}

R120941, '7 km SE of Woodleigh Outstation,

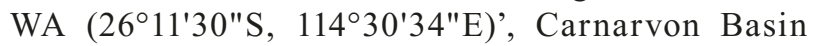
Biological Survey team [A.A. Burbidge, P.J. Fuller, A. Desmond, M.S. Harvey and J.M. Waldock], collected 11 October 1994.

\section{Paratypes (50)}

R8159-60, Warroora, WA; R15278, R55189, Overlander Roadhouse, WA; R28654, $10 \mathrm{mi}$ [16 km] S Shark Bay turnoff, Northwestern Hwy, WA; R36748, R40669, R41589, R177657, Callagiddy HS, WA; R54843, 7 km W Hamelin HS, WA; R60412-13, Bullara, WA; R60618, 6 km NE Mungawolagudi, WA; R61089, 14 km W Giralia HS, WA; R61129-32, 2 km E Bullara, WA; R61265-66, 26 km W Giralia HS, WA; R71110, 18.4 km $\mathrm{N}$ Yaringa HS, WA; R71308, $3 \mathrm{~km}$ W Winning HS, WA; R71572, 5 km SE Gnaraloo HS, WA; R120715, R123460, R126758, 9.8 km E Mardathuna HS, WA; R120870, R120881, 13.5 km SE Woodleigh OS, WA; R120872*, R120884, R120925, R120939, R122961, R125075, 7 km SE Woodleigh OS, WA; R120982, R121013, R122579, R122658，R122666, R124989, 9.7 km NE Meedo HS, WA; R121050, R122527, R122550-51, R122560, R122650, R126691, 10.9 km NE Meedo HS, WA; R121610, 1.25 km NE Meedo HS, WA; R126905, 14 km E Cape Cuvier, WA; R131016, $11 \mathrm{~km}$ WNW Woodleigh OS, WA.

\section{Remarks}

There are two specimens of D. klugei associated with the registration number R36748. One of these two specimens also has a second registration tag (R37547) indicating reregistration; however, this number is already associated with a specimen of Ctenophorus caudicinctus. Review of accession data shows the correct specimen first associated with this registration number is the Ctenophorus caudicinctus specimen accessioned 5 August 1970. The duplication of registration numbers is likely to be attributed to the past use of dymo-printed labels as registration tags which were created on an 'as needed' on demand basis with erroneous duplication occurring occasionally (pers. obs.). It is not known if Aplin and Adams were aware of the two specimens and if both or only one was used for the species description. The specimen with the two duplicate registration numbers (R36748 and R37547) has been reregistered as R177657 and is maintained as a paratype specimen. One specimen, R120872, was not located during the type audit or during a previous type specimen audit undertaken in 2008 and is considered lost. Heart of holotype stored frozen $\left(-75^{\circ} \mathrm{C}\right)$ at WAM. Liver and heart of 15 paratypes (R120872，R120982，R121013，R121050，R122527, R122550，R122560，R122579，R122650，R122666, R122961, R124989, R126758, R126905, R131016) and heart of six paratypes (R120715, R120870, R120881, $\mathrm{R} 120884, \mathrm{R} 120925$, R120939) stored frozen $\left(-75^{\circ} \mathrm{C}\right)$ at WAM.

\section{Diplodactylus lateroides \\ Doughty \& Oliver, 2013}

Doughty, P. and Oliver, P.M. (2013) Systematics of Diplodactylus (Squamata: Diplodactylidae) from the south-western Australian biodiversity hotspot: redefinition of $D$. polyopthalmus and the description of two new species. Records of the Western Australian Museum 28: 44-65 [55].

\section{Holotype}

R156613, 'Mount Dale, WA (3208'S, $\left.116^{\circ} 18^{\prime} \mathrm{E}\right)$ ', B. Maryan and P. Orange, 4 June 2005.

\section{Paratypes (5)}

R117867, Byford, WA; R121167, Cooliabberra Spring, WA; R135539 Kingston State Forest, WA; R154719, Dwellingup area, WA; R156612, Mt Dale, WA.

\section{Remarks}

Liver of the holotype and three paratypes (R117867, R121167, R156612), heart of one paratype (R121167) stored frozen $\left(-75^{\circ} \mathrm{C}\right)$ and liver of one paratype (R135539) stored in $100 \%$ ethanol.

\section{Diplodactylus maini Kluge, 1962}

Kluge, A.G. (1962a) A new species of gekkonid lizard, genus Diplodactylus (Gray), from the southern interior of Western Australia. Western Australian Naturalist 8(4): 97-101 [98].

\section{Holotype}

R12242, '10 miles [16 km] south of Queen Victoria Spring (33 miles $[53 \mathrm{~km}]$ north of Zanthus), WA' $\left(17^{\circ} 10^{\prime} \mathrm{S}, 128^{\circ} 18^{\prime} \mathrm{E}\right)$, A.R. Main, 2 October 1956.

\section{Paratypes (7)}

R4183, Kulin, WA; R15274, R15275, Newman Rock, $88 \mathrm{mi}$ [141 km] E Norseman, WA; R? (three specimens*; now UMMZ 127538-39), unknown locality; R?*, Warburton Mission, WA.

\section{Current nomenclature}

Lucasium maini, see Oliver et al. (2007).

\section{Remarks}

No paratypes were designated by Kluge in the original description; however, seven additional specimens examined and listed under variation (some with WAM registrations and others without registrations from the UWA Zoology Department) are considered paratypes in accordance with Article 7.2.1.1 and Article 72.4.5 of the Code (ICZN 1999). Kluge includes three specimens without locality data from the UWA Zoology Department; however, no record of these specimens could be found in current or past WAM catalogues or registers. In a later publication, Kluge (1967) refers to 
five specimens without locality data, including three in his collection (AK 566, 1378-9) which are likely to be the specimens referred to in the description of $D$. maini, the remaining two had the collection locality of Perth which was deemed to be in error by Kluge. All three AK specimens are now held in the UMMZ collection (UMMZ 127538 (formerly AK 566) and 127539 (formerly AK 1378-79). The single specimen from Warburton Mission tentatively assigned to $D$. maini by Kluge is likely to be a specimen of Lucasium stenodactylum. A single UWA uncatalogued specimen from Warburton was referred to by Kluge (1967) under Diplodactylus stenodactylus (=Lucasium stenodactylum) which may be the specimen Kluge referred to in the $D$. maini description; however, the current whereabouts of this specimen is unknown.

\section{Diplodactylus memillani Storr, 1978}

Storr, G.M. (1978a) Seven new gekkonid lizards from Western Australia. Records of the Western Australian Museum 6(3): 337-352 [341].

\section{Holotype}

R43230, 'Mitchell Plateau, WA (145' S, $\left.126^{\circ} 00^{\prime} \mathrm{E}\right)$ ', L.A. Smith and R.E. Johnstone, 20 February 1973.

\section{Paratypes (39)}

R28186, King Edward River, WA; R43039-41, R43064-65, R43076-78, R56188-205, Crystal Creek, Port Warrender, WA; R43125-26, R43222* (now MCZ R158528), R43223* (now MCZ R158529), R43225-29, Mitchell Plateau, WA; R47696 [in error, R37696], Manning Creek, WA; R50536, Drysdale River NP, WA; R57323, Old Theda, WA.

\section{Current nomenclature}

Strophurus mcmillani, see Greer (1989).

\section{Remarks}

Two paratype specimens, R43222-23, were gifted to MCZ (now MCZ R158528-29) on 17 December 1979 and are no longer held in the WAM collection. One paratype registration number, R47696, is associated with a specimen of Cryptophis pallidiceps from Berry Springs, NT; the correct registration matching the species and locality information presented by Storr is R37696.

\section{Diplodactylus mitchelli Kluge, 1963}

Kluge, A.G. (1963a) Three new species of the gekkonid lizard genus Diplodactylus Gray from Australia. Records of the South Australian Museum 14: 545-553 [548].

\section{Holotype}

R14823, 'Coolawanyah homestead, Pilbara Division,

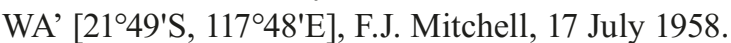

\section{Paratype}

R14824, Coolawanyah HS, WA.

\section{Remarks}

Kluge referred to one additional specimen under 'variation' as an uncatalogued specimen from Shothole Canyon, 12 mi [19.3 km] NNW Learmonth, North West Cape held at UWA. Kluge (1967) referrs to a single specimen from the above locality under specimens examined of $D$. mitchelli with a UMMZ registration (UMMZ 126647) which is likely to be the unregistered UWA specimen referred to by Kluge (1963a). This specimen is likely Diplodactylus capensis (Doughty et al. 2007) which is endemic to the North West Cape whereas $D$. mitchelli is restricted to the Pilbara region. Two additional paratypes are held in the SAMA collection (SAMA R4280 and R4281).

\section{Diplodactylus nebulosus Doughty \& Oliver, 2013}

Doughty, P. and Oliver, P.M. (2013) Systematics of Diplodactylus (Squamata: Diplodactylidae) from the south-western Australian biodiversity hotspot: redefinition of $D$. polyopthalmus and the description of two new species. Records of the Western Australian Museum 28: 44-65 [52].

\section{Holotype}

R168639, 'Moresby Range, WA $\left(28.6275^{\circ} \mathrm{S}\right.$; $\left.114.6703^{\circ} \mathrm{E}\right)^{\prime}$ [ [28 $\left.37^{\prime} 39^{\prime \prime S}, 114^{\circ} 40^{\prime} 13^{\prime \prime E}\right]$, B. Maryan and D. Algaba, 16 June 2009.

\section{Paratypes (9)}

R61318, $20 \mathrm{~km}$ east of Green Head, WA; R100225, $\sim 7 \mathrm{~km}$ north-east of Mt Lesueur, WA; R119081, Yetna, WA; R128545, R128551, Lesueur NP, WA; R166718, Mt Lesueur, WA; R168638, R168640-41, Moresby Range, WA.

\section{Remarks}

Liver of holotype and five paratypes (R1190814, R166718, R168638, R168640-41) and heart of one paratype (R119081) stored frozen $\left(-75^{\circ} \mathrm{C}\right)$ at WAM.

\section{Diplodactylus rankini Storr, 1979}

Storr, G.M. (1979b) Five new lizards from Western Australia. Records of the Western Australian Museum 8(1): 134-142 [134].

\section{Holotype}

R61474, 'mouth of Yardie Creek, WA $\left(22^{\circ} 20^{\prime} \mathrm{S}\right.$, 113²48'E)', G. Harold and G. Barron, 7 December 1978. 


\section{Paratypes (10)}

R15220* (now MCZ R158536), Point Cloates, WA; R31940, Coral Bay, WA; R61171-73, R61482, mouth of Yardie Creek, WA; R61407-10, Ningaloo, WA.

\section{Current nomenclature}

Strophurus rankini, see Greer (1989).

\section{Remarks}

One paratype, R15220, was exchanged with MCZ on 11 April 1980; it is now MCZ R158536.

\section{Diplodactylus robinsoni Smith, 1995}

Smith, L.A. (1995) A new Diplodactylus, subgenus Strophurus (Lacertilia: Gekkonidae) from northern Australia. Records of the Western Australian Museum 17: $351-353$ [351].

\section{Holotype}

R108646, 'Mt Parker, Osmond Range, WA (17010'S, 128¹8'E)', N. Gambold, 21 July 1991.

\section{Paratypes (3)}

R67960, $7 \mathrm{~km}$ SE Mt Septimus, NT; R108645, R108647, Wade Creek, WA.

\section{Current nomenclature}

Strophurus robinsoni, see Greer (1989) and Aplin and Smith (2001).

\section{Diplodactylus savagei Kluge, 1963}

Kluge, A.G. (1963a) Three new species of the gekkonid lizard genus Diplodactylus Gray from Australia. Records of the South Australian Museum 14: 545-553 [550].

\section{Holotype}

R14369, 'Marble Bar, Pilbara Division, WA' [21ํํ'S, 11944'E], G.M. Storr, 22 September [August] 1960.

\section{Remarks}

The holotype's entry into the original registration catalogue is listed under the date 22 August 1960. Three additional specimens are held in the SAMA collection, SAMA R3464A-B and R4282. In the original description, Kluge does not designate any paratypes; however, the three SAMA specimens (SAMA $\mathrm{R} 3464 \mathrm{~A}-\mathrm{B}$ and $\mathrm{R} 4282$ ) listed under variation are considered paratypes under Article 72.1.1 and Article 72.4.5 of the Code (ICZN 1999).

\section{Diplodactylus spinigerus aberrans Glauert, 1952}

Glauert, L. (1952) Herpetological miscellanea. I. Notes on some forms of Diplodactylus. Western Australian Naturalist 3: 166-168 [167].

\section{Holotype}

R2803, 'Mt Wynne, West Kimberley, WA' $\left[18^{\circ} 06^{\prime} \mathrm{S}\right.$, $124^{\circ} 27^{\prime} \mathrm{E}$ ], E.W. Bennett [possibly in error], collection date unknown, accessioned 30 September 1929.

\section{Current status}

Strophurus ciliaris aberrans, see Greer (1989) for generic allocation and Storr (1988d) for speciessubspecies combination.

\section{Remarks}

Early registration data for the holotype specimen does not list a collector in the collector/donor column, though the previous entry for R2802 lists E.W. Bennett. In early hardcopy specimen registration catalogues, where multiple specimens were provided by the same individual, the collector/donor column was often not completed for every entry, indicating the entry was the same as the previous entry. An annotation associated with R2803 states 'squirted stuff like cobweb out of the spines on its tail' which Glauert also refers to in the species description with a different donor, stating 'It will be of interest to record that the donor of one of the specimens in the collection, Mr. H.W.B. Talbot, mentioned that the lizard 'squirted out stuff like cobweb from the spines on its tail,' a habit I have observed on occasion...' No other specimens with H.W.B. Talbot listed as collector could be located in the collection and it cannot be confirmed which of the two is the collector of the type specimen, or if the annotations in the catalogue refer to another specimen, and E. W. Bennett is maintained as the collector/donor of the type specimen. The original entry for R2803 lists 'Diplodactylus ciliaris spinigerus' as the species, with ciliaris since crossed out and 'var. aberrans' written above it, followed by 'Paratype' and initialled 'LG' [Ludwig Glauert]. No other specimens available to Glauert from the localities mentioned in the description have any annotations pertaining to type designations and Glauert's paratype annotation associated with R2803 is considered to be in error.

\section{Diplodactylus spinigerus inornatus Storr, 1988}

Storr, G.M. (1988c) The subspecies of Diplodactylus spinigerus (Lacertilia: Gekkonidae). Records of the Western Australian Museum 14: 177-182 [180].

\section{Holotype}

R78354, 'Frank Hann National Park, WA (32 $58^{\circ}$ 'S, $120^{\circ} 06^{\prime}$ E)', B.G. Muir, 17 [14] November 1980.

\section{Paratypes (89)}

R679, R96996, Kalamunda, WA; R716, Bickley, WA; R1202, Swan View, WA; R1994, Tolls Pass, Stirling Range, WA; R2176, Darlington, WA; R2320, Cunderdin, WA; R4372, Kulin, WA; R4441, Yoting, WA; R9674, 
Calyerup, WA; R15241, R95400, East Mt Barren, WA; R31116, 8 km W Israelite Bay, WA; R13296, R96992, 10 km S Nyabing, WA; R19666-67, R61343, Lesmurdie, WA; R25360, Boya, WA; R36678-79, 8 km N Pingaring, WA; R39094, Mt Hampton, WA; R39844, R39858-60, R39880, R39885, Greenshield Soak, WA; R39914-17, 3 km W Greenshield Soak, WA; R41923, R41934, Duke of Orleans Bay, WA; R42617, 10 km SE Ongerup, WA; R42975, R43732, R43739, Dragon Rocks Reserve, WA; R43401, R64887, R67512-13, 12 km ENE Bendering, WA; R44972 [in error, R44971], 18 km W Point Culver, WA; R49760-61, Dongolocking Reserves, WA; R49952, Mundaring Weir, WA; R52440, 11 km E Quairading, WA; R52563-64, R55302-04, 7 km ENE Bendering, WA; R55931, R56059, R56060, Fitzgerald Inlet, WA; R55935, $5 \mathrm{~km} \mathrm{~N}$ Hopetoun, WA; R56057, $25 \mathrm{~km} \mathrm{~N}$ Forrestania, WA; R56558, 25 km N Kellerberrin, WA; R56923, Cape Range NP, WA; R58226, 20 km NE Dalwallinu, WA; R65153, R68057-58, 7.5 km WSW Lake Cronin, WA; R65364, R66081, North Ironcap, WA; R66088-89, South Ironcap, WA; R66988, 7 km NE Toolinna Rockhole, WA; R69972, R78352, R81415, Frank Hann NP, WA; R71867, Borayukkin Rock, WA; R77949, 11 km W Point Dempster, WA; R86660, Lort River, WA; R86995, mouth of Thomas River, WA; R88103, Walyunga NP, WA; R89288, R94285, Fitzgerald River NP, WA; R89389, Culham Inlet, WA; R89476-78, Yorkinup Bay, WA; R90341 [in error, R93041], R93045, Mooliabeenee, WA; R91075, Bluff Knoll Rd, WA; R96964, 33 km NE Jerramungup, WA; R96693, 25 km SE Kukerin, WA; R96994, Ravensthorpe, WA; R97249, $19 \mathrm{~km}$ N Bencubbin, WA.

\section{Current nomenclature}

Strophurus spinigerus inornatus, see Greer (1989).

\section{Remarks}

Storr (1988c) states '88 specimens listed under Material' under paratypes; however, 89 specimens (excluding the holotype) are presented under material. It is not clear which specimen is not a paratype or if the statement is in error. All 89 specimens are considered as paratypes here. The registration numbers for two paratypes presented by Storr are in error, R90341 and R44972. There is no entry for R90341 in the hardcopy register and no specimens bearing the registration number could be found in the Strophurus collection, indicating the registration number has not been used and the number listed by Storr was in error. A specimen of Strophurus spinigerus inornatus matching the locality data presented by Storr registered as R93041 was found with the rest of the paratypes of the subspecies and is presumed to be the correct specimen to which Storr was referring. The registration number R44972 refers to a specimen of Morethia obscura from west of Point Culver. The correct registration matching the locality data presented by Storr is R44971. The collection date of the holotype, as presented by Storr, is in error; the correct date, as stated in accession data for the specimen, is 14 November 1980. Liver sample of two paratypes (R77949, R97249) stored frozen $\left(-75^{\circ} \mathrm{C}\right)$ at WAM.

\section{Diplodactylus squarrosus Kluge, 1962}

Kluge, A.G. (1962b) A new species of gekkonid lizard, genus Diplodactylus, from the Carnarvon region, Western Australia. Western Australian Naturalists 8(3): 73-75 [73].

\section{Holotype}

R13805, 'Hamelin Pool, Shark Bay, WA' [17²10'S, 128 $18^{\prime}$ E]. W.H. Butler, 14 May 1959.

\section{Paratypes (4)}

R? (three specimens)*, $7 \mathrm{mi}[11 \mathrm{~km}] \mathrm{N} ; \mathrm{R}$ ? $12 \mathrm{mi}[19$ $\mathrm{km}$ ] S Booloogooroo, WA.

\section{Current nomenclature}

Lucasium squarrosum, see Oliver et al. (2007).

\section{Remarks}

Kluge did not designate any paratype specimens; however, the four specimens mentioned under the variation section of the original description are considered paratypes under Article 72.1.1 and Article 72.4 .5 of the Code (ICZN 1999). Kluge provides only locality data for the four paratypes with no indication of specimen locations or registration numbers of WAM specimens. No specimens matching the locality information provided could be found in the WAM collection; however, Kluge (1967) refers to four $D$. squarrosus specimens under material examined from the localities in the species description, including AK 100 (now UMMZ 127547) and three uncatalogued UWA specimens from ' 7 miles N. Booloogooroo' and UMMZ 126657 (formerly AK 340) from ' 12 miles S. Booloogooroo'. Of the specimens referred to by Kluge (1967), UMMZ 126657 is likely to be one of the paratypes referred to in the species description and the series of three unregistered UWA specimens were possibly the remaining three; however, the current whereabouts and status of these specimens is unknown.

\section{Diplodactylus wellingtonae Storr, 1988}

Storr, G.M. (1988d) The Diplodactylus ciliaris complex (Lacertilia: Gekkonidae) in Western Australia. Records of the Western Australian Museum 14(1): 121-133 [126].

\section{Holotype}

R15218, '40 km NE Laverton, WA (28³3'S, 122³5'E)', G.M. Storr, 23 August 1961. 


\section{Paratypes (62)}

R142, R11565, Laverton, WA; R328-29, Quinns, WA; R735-76, Cue District, WA; R5194, Gabanintha, WA; R8963, Austin Downs, WA; R10019, Leonora, WA; R15216, Nallan, WA; R15217, R86640, 48 km S Leonora, WA; R15219, $40 \mathrm{~km}$ NE Laverton, WA; R19769, R27216, Kathleen Valley, WA; R21112, 57 km E Wiluna, WA; R22709, Meekatharra District, WA; R28954, Glenburgh, WA; R29638, Wiluna, WA; R30973, nr Albion Downs, WA; R36714, Canning Gap, WA; R51621, 10 km NE Mt Newman, WA; R51920-21, Carnarvon Range, WA; R52883, R52889, Mt Augustus, WA; R54231, Ophthalmia Range, WA; R56005-06, 12 km S Laverton, WA; R60520, Wonganoo, WA; R61788, $61 \mathrm{~km}$ NW Prairie Downs, WA; R62785-88, 21 km SE Mt Keith, WA; R65778, 14 km ENE Comet Vale, WA; R65819, 12 km NE Comet Vale, WA; R65871, R65997, R72762, Mt Linden, WA; R66315-16, 31-35 km SW Mt Meharry, WA; R69788, Marandoo, WA; R70850, 20 km NNW Mt Windarra, WA; R72895, 8 km SSE Mt Linden, WA; R74869, R74871, 15 km S Hooley, WA; R74926, 2 km W Hamersley HS, WA; R81320, 2 km S Capricorn Roadhouse, WA; R83730, $10 \mathrm{~km} \mathrm{~S}$ Turee Creek, WA; R84377, 32 km SSW Paroo, WA; R84434, $23 \mathrm{~km}$ SSW Anketell, WA; R86638, $40 \mathrm{~km}$ S Leonora, WA; R87463, $3 \mathrm{~km}$ E White Well, WA; R87484-86, 20 km E Millbillillie, WA; R87491, 26 km W Prenti Downs, WA; R94713, Lorna Glen, WA; R95544, 4 km N Jeedamya HS, WA; R95548, 27 km S Leonora, WA; R95551, 7 km NE Menzies, WA.

\section{Current nomenclature}

Strophurus wellingtonae, see Greer (1989).

\section{Remarks}

In the original description Storr states under paratypes, 'for 61 specimens see Material'; however, 62 specimens are listed under that heading. It is not known if this is a typographical error or one specimen was not supposed to be listed, and as there is no further information indicating the author's intent, all specimens listed under Material are considered here as paratypes. The holotype is not listed under Material.

\section{Diplodactylus wilsoni Storr, 1983}

Storr, G.M. (1983) Two new lizards from Western Australia (genera Diplodactylus and Lerista). Records of the Western Australian Museum 11: 59-62 [59].

\section{Holotype}

R78932, ' $25 \mathrm{~km} \mathrm{NNW}$ of Waldburg, WA (243' S, 117²1'E)', S.K. Wilson, 28 July 1982.

\section{Paratypes (5)}

R78930, Mt Clere Stn, WA; R78931, 21 km SW Waldburg, WA; R81213-15, 19 km SW Waldburg, WA.

\section{Current nomenclature}

Strophurus wilsoni, see Greer (1989).

\section{Diplodactylus wiru Hutchinson, Doughty \& Oliver, 2009}

Hutchinson, M.N., Doughty, P. and Oliver, P.M. (2009) Taxonomic revision of the stone geckos (Squamata: Diplodactylidae: Diplodactylus) of southern Australia. Zootaxa 2167: 25-46 [39].

\section{Paratypes (3)}

R100622, R135291, $25 \mathrm{~km}$ NNE Queen Victoria Spring, WA; R157876, $25 \mathrm{~km}$ NNE Queen Victoria Spring [in error, Balladonia Roadhouse, Eyre Hwy], WA.

\section{Remarks}

Holotype held in the SAMA collection, R59908 '15

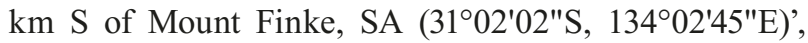
collected by D. Armstrong, 27 November 2004. An additional 19 paratypes held in the SAMA collection (SAMA R18202, R31848, R31863, R31942, R31946-47, R31951，R31963，R32052，R32097，R45552，R57217， R59458, R61154, R62000-01, R62293, R62367, R62465). Liver samples of two paratypes (R135291, R157876) stored frozen $\left(-75^{\circ} \mathrm{C}\right)$ at WAM.

\section{Diplodactylus wombeyi Storr, 1978}

Storr, G.M. (1978a) Seven new gekkonid lizards from Western Australia. Records of the Western Australian Museum 6(3): 337-352 [344].

\section{Holotype}

R36747, 'Cockeraga River, WA ( $\left.22^{\circ} 05^{\prime} \mathrm{S}, 118^{\circ} 48^{\prime} \mathrm{E}\right)$ ', J.C. Wombey, 18 June 1970.

\section{Paratypes (5)}

R36597, R37061-62, R37063*, R37064, Cockeraga River, WA.

\section{Remarks}

One paratype (R37063) was not located during the audit; the presence of the specimen was last confirmed during a type audit in 2008 .

\section{Diplodactylus woodwardi Fry, 1914}

Fry, D.B. (1914) On a collection of reptiles and batrachians from Western Australia. Records of the Western Australian Museum 1: 174-201 [175].

\section{Holotype}

R14370 (formerly WAM 9876), 'Western Australia' [Strelley River, Pilbara Division, WA $\left(20^{\circ} 33^{\prime} \mathrm{S}\right.$, $\left.\left.119^{\circ} 00^{\prime} \mathrm{E}\right)\right]$, J.B. Cleland, collection date unknown, presumably 1907 , first accessioned into WAM collection as 9876 on 27 March 1909 (Figure 1).

\section{Current status}

Junior synonym of Lucasium stenodactylum (Boulenger, 1896), see Kluge (1967). 

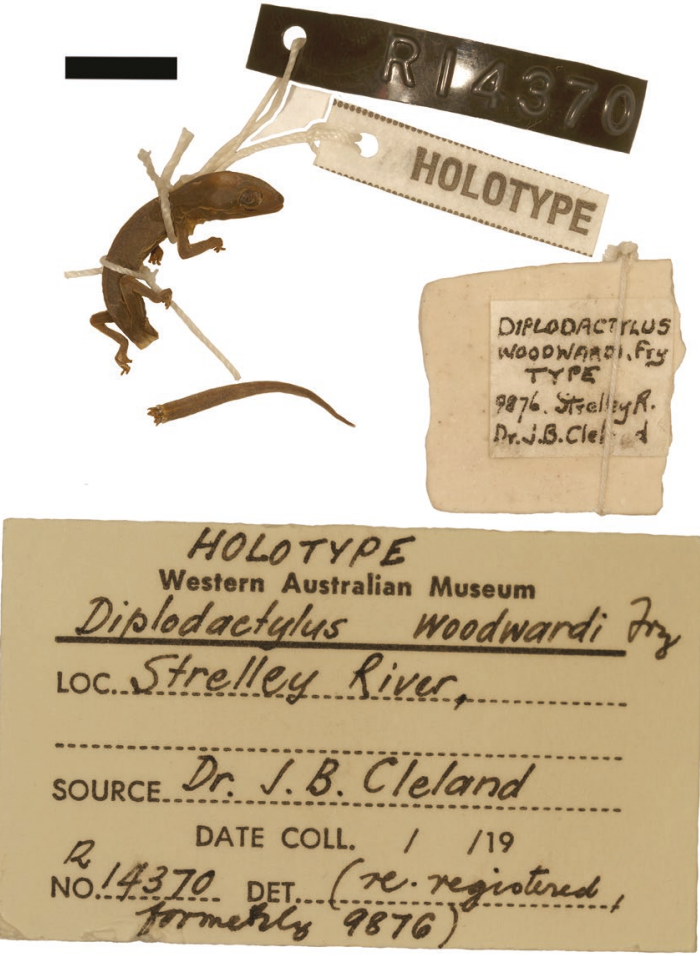

FIGURE 1 Diplodactylus woodwardi Fry, 1914 holotype (R14370, formerly 9876) and associated loose labels. Scale bar $=10 \mathrm{~mm}$.

\section{Remarks}

Prior to staff with herpetological interests commencing at the WAM, Bernard Henry Woodward, the then Director, had specimens sent to Dene Barrett Fry at the AMS for identification. This was a common practice during earlier years of the institution for obtaining identifications of groups for which the WAM staff lacked knowledge. Fry subsequently published the descriptions of some new species in 1914 from among the material loaned to him, including $D$. woodwardi, together with another gecko, Peropus variegatus punctatus (= Gehyra punctata), and a pygopod, Ophioseps (= Aprasia) repens. Fry (1914) did not provide any reference to the registration number of the type specimen and only stated 'Western Australia' as the type locality. In the type specimens list collated by Storr and presented in the WAM 1960-61 Annual Report, R14370 was identified as the holotype (Anonymous 1961). Kluge (1963) also listed R14370 as the holotype and first presented the type locality of the species as 'Strelley River, Pilbara Division, Western Australia', based on information accompanying the specimen, and listed it as a junior synonym of Diplodactylus stenodactylus (= Lucasium stenodactylum). Kluge also noted the specimen was in poor condition as it was extremely desiccated and devoid of all colour and pattern. Although the collection date of the specimen is not listed in the
WAM register or species description, John Burton Cleland, a Pathologist with the Health Department, was reported as being sent to Port Hedland in the Pilbara region from August to October 1907 to investigate trypanosome disease in imported camels, accompanied by entomologist H.M. Giles (Anonymous 1907a, 1907b, 1908). During this time, he also recorded notes on birds observed during part of the expedition at Strelley River (Port Hedland-Marble Bar Road) during AugustOctober 1907 where he also collected a Painted Firetail (Emblema picta) nest that was subsequently deposited at the WAM (Cleland 1909). It is likely the type of $D$. woodwardi was collected sometime during his time in the Pilbara in 1907.

The holotype identified by Storr in the 1960-61 Annual Report (Anonymous 1961) was formerly registered as ' 9876 ' prior to being reregistered into the herpetology collection as R14370 on 12 July 1962 according to notations next to the specimen's entry in early specimen catalogues. The early general collection specimen catalogue (pre R prefix) list the original registration number (9876) which as originally identified as 'Newt', with 'Diplodactylus woodwardi, Fry TYPE' written in Glauert's hand over the top. A second notation by Glen Storr from 12 July 1962 states 'reregistered as R14370' and 'mounted'. Accompanying the holotype specimen is a small stone tile with a handwritten label in an unknown hand (possibly Fry's) tied to it which states 'DIPLODACTYLUS WOODWARDI, Fry' with 'TYPE' and '9876, Strelley R. Dr J.B. Cleland' below. It is likely the specimen was mounted to the tile prior to being reregistered in 1962 when a dymo-printed registration tag was tied to the specimen.

Molecular work by Pepper et al. (2006) indicate Lucasium stenodactylum occurring in the Pilbara region are a divergent lineage and likely to represent a different species for which this name is available and may apply.

\section{Lucasium bungabinna Doughty \& Hutchinson, 2008}

Doughty, P. and Hutchinson, M.N. (2008) A new species of Lucasium (Squamata: Diplodactylidae) from the southern deserts of Western Australia and South Australia. Records of the Western Australian Museum 25: 95-106 [97].

\section{Holotype}

R166888, Bungalbin Hill, WA $\left(30^{\circ} 17^{\prime} 40^{\prime \prime} \mathrm{S}\right.$, 11944'50"E), D. Robinson, 7 April 2007.

\section{Paratypes (11)}

R121955-56, Bungalbin Hill, WA; R126400, R126405, Bungalbin Sandplain, WA; R151202, 20 km E Sandstone, WA; R147385, R155409-10, R155412-13, R155417, 7-8 km WNW Point Salvation, WA. 


\section{Remarks}

An additional 10 paratypes held in the SAMA collection (R56597, R59368, R59774, R60342, R61197, R61310, R61443, R62250, R62265, R62338). Liver sample of holotype and three paratypes (R126400, R126405, R151202) and heart of three paratypes (R121956, R126400, R126405) stored frozen $\left(-75^{\circ} \mathrm{C}\right)$ at WAM.

\section{Oedura filicipoda King, 1984}

King, M. (1984b) Three new species of Oedura (Reptilia: Gekkonidae) from the Mitchell Plateau of north Western Australia. Amphibia-Reptilia 5: 329337 [332].

\section{Holotype}

R83707, 'near the Mitchell Plateau, WA (1453'25"S, 12544'35"E)', R. How, 20 January 1982.

\section{Paratype}

R83708, nr Mitchell Plateau, WA.

\section{Oedura fimbria Oliver \& Doughty, 2016}

Oliver, P.M. and Doughty, P. (2016) Systematic revision of the marbled velvet geckos (Oedura marmorata species complex, Diplodactylidae) from the Australian arid and semi-arid zones. Zootaxa 4088(2): 151-176 [168].

\section{Holotype}

R154783, 'Brockman Ridge, WA $\left(23.3108^{\circ} \mathrm{S}\right.$, $\left.119.9169^{\circ} \mathrm{E}\right)^{\prime}$ [ $\left[23^{\circ} 18^{\prime} 38^{\prime \prime S}, 119^{\circ} 55^{\prime} 00^{\prime \prime E}\right]$, J. Fraser, 5 April 2004.

\section{Paratypes (14)}

R105965, 7 km N Mt Magnet, WA; R119991, R119993, Hope Downs, WA; R129595, R129635, 120 km NW Newman, WA; R135369, Mt Brockman, WA; R15479697, Walga Rock, WA; R157504, R157508, R157516, Packsaddle Range, WA; R157595, West Angelas, WA; R160074, 32.5 km ESE Meentheena Outcamp, WA; R165150, 5 km NNW Python Pool, WA.

\section{Remarks}

Liver of holotype stored frozen $\left(-75^{\circ} \mathrm{C}\right)$ at WAM. Liver of 11 paratypes (R119993, R129595. R135369, R15479697, R157504，R157508，R157516，R157595，R160074, R165150) and heart of three (R105965, R119991, $\mathrm{R} 135369)$ stored frozen $\left(-75^{\circ} \mathrm{C}\right)$ at WAM.

\section{Oedura gracilis King, 1984}

King, M. (1984b) Three new species of Oedura (Reptilia: Gekkonidae) from the Mitchell Plateau of north Western Australia. Amphibia-Reptilia 5: 329-337 [334].

\section{Holotype}

R83709, "near the Mitchell Plateau, WA (1453'30"S, 1254'00"E)', R. How, 21 January 1982.

\section{Paratype}

R83710, Walsh Point, WA.

\section{Oedura murrumanu Oliver, Laver, Melville \& Doughty, 2014}

Oliver, P.M., Laver, R.J., Melville, J. and Doughty, P. (2014b) A new species of velvet gecko (Oedura: Diplodactylidae) from the limestone ranges of the southern Kimberley, Western Australia. Zootaxa 3873(1): 49-61 [51].

\section{Holotype}

R173368 (field no. PMO54), 'Oscar Range, WA

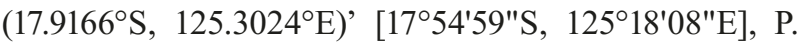
Oliver, P. Horner and S. Perkins, 28 October 2013.

\section{Paratypes (2)}

R173369 (field number PMO52), R173370 (field no. PMO56), Oscar Range, WA.

\section{Remarks}

Three additional paratypes held in the NMV collection (NMV D76948 (field no. PMO55), D77002 (field no. PMO51), D76947 (field no. PMO53).

\section{Oedura obscura King, 1984}

King, M. (1984b) Three new species of Oedura (Reptilia: Gekkonidae) from the Mitchell Plateau of north Western Australia. Amphibia-Reptilia 5: 329337 [330].

\section{Holotype}

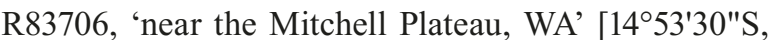
1254'00"E], J. Dell, 27 July 1982.

\section{Current nomenclature}

Amalosia obscura, see Oliver et al. (2012).

\section{Oedura reticulata Bustard, 1969}

Bustard, H.R. (1969) Oedura reticulata, a new velvet gecko from south-west Western Australia. Western Australian Naturalist 11: 82-85 [83].

\section{Holotype}

R23350, '9 miles [14.4 km] N Kalanning, WA

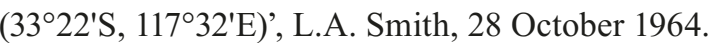

\section{Paratypes (10)}

R4407* (now MCZ R158553), Kulin, WA; R5932, Northam, WA; R6380* (now MCZ R158554), Dedari, WA; R6580, Spencer's Brook, WA; R12790, Dryandra, 
WA; R15296, 11 km SE Bindoon Hill, WA; R21989, $66 \mathrm{~km}$ E Southern Cross, WA; R26450* (now MCZ R158555), 24 km S Holt Rock, WA; R29085 [in error, R29055], 12 km W Wandering, WA; R29379, 6 km E Holt Rock, WA.

\section{Current nomenclature}

Hesperoedura reticulata, see Oliver et al. (2012).

\section{Remarks}

One registration number presented by Bustard is in error, R29085 is associated with a specimen of agamid, Ctenophorus isolepis isolepis from Roebourne, WA. The correct registration number matching the locality information presented by Bustard is R29055. Three paratypes (R4407, R6380 and R26450) were gifted to MCZ in April 1980 (now MCZ R158553-55). Four additional paratype specimens held in other collections: two at NMV (NMV D1689, D2450) and two at QM (QM R13858, R13859).

\section{Phyllodactylus strophurus Duméril \& Bibron, 1836}

Duméril, A.M.C. and Bibron, G. (1836) Erpétologie Générale ou Histoire Naturelle Complète des Reptiles. Vol. 3. Librairie Encyclopédique de Roret, Paris. 517 pp. [397, pl. 32, fig. 1].

\section{Neotype}

R6535, '[Gullewa via] Yalgoo, WA' [28³9'S, $\left.116^{\circ} 39^{\prime} \mathrm{E}\right]$, collected by V. Walker, collection date unknown, designated by Kluge (1967).

\section{Current Nomenclature}

Strophurus strophurus, see Wells and Wellington (1984).

\section{Remarks}

In their original description, Duméril and Bibron provide the type locality of 'baie des Chiens marins' [= Shark Bay] and identify [J.R.C.] Quoy and [J.P.] Gaymard as collectors (Kluge 1967). The original type was held in the collection of Muséum National d'Histoire Naturelle Paris, but was already missing as early as 1851 (Duméril and Duméril 1851; Brygoo 1990), prompting Kluge (1967) to designate a neotype. The neotype locality presented by Kluge is not precise, original accession data (3 August 1937) lists the locality as 'Gullewa via Yalgoo' and not just 'Yalgoo' as presented by Kluge.

\section{Pseudothecadactylus lindneri cavaticus Cogger, 1975}

Cogger, H.G. (1975) New lizards of the genus Pseudothecadactylus (Lacertilia: Gekkonidae) from Arnhem Land and northwestern Australia. Records of the Australian Museum 30: 87-97 [93].

\section{Holotype}

R43176, 'near Mitchell River Falls, approximately 25 $\mathrm{km}$ southwest of Crystal Head, Port Warrender, WA $\left(14^{\circ} 40^{\prime} \mathrm{S}, 125^{\circ} 42^{\prime} \mathrm{E}\right)^{\prime}$, L.A. Smith and R.E. Johnstone, 14 January 1973.

\section{Paratypes (2)}

R43137, Surveyors Pool, Mitchell Plateau, WA; R43175, nr Mitchell River Falls, approx. 25 km SW Crystal Head, Port Warrender, WA.

\section{Current status}

Pseudothecadactylus cavaticus, see Smith (1989).

\section{Rhynchoedura sexapora Pepper, Doughty, Hutchinson \& Keogh, 2011}

Pepper, M., Doughty, P., Hutchinson, M.N. and Keogh, J.S. (2011) Ancient drainages divide cryptic species in Australia's arid zone: Morphological and multigene evidence for four new species of beaked geckos (Rhynchoedura). Molecular Phylogenetics and Evolution 61: 810-822 [817].

\section{Holotype}

R170241 (formerly AMS R139904), 'E1 Questro Station, WA $\left(-16.01861^{\circ} \mathrm{S}, 128.00389^{\circ} \mathrm{E}\right)$ ' [16 $01^{\circ} 07^{\prime} \mathrm{S}$, 128 00'14"E], H. Cogger et al., 1 September 1992.

\section{Paratypes (2)}

R132755, Carlton Hill Stn, WA; R164785, 35 km W Kununurra, WA.

\section{Remarks}

Holotype formerly held in the AMS collection, registered as AMS R139904. Four additional paratypes held in the AMS collection (AMS R117265, R139902, R139905, R139903). Liver of two paratypes stored at WAM, one stored frozen $\left(-75^{\circ} \mathrm{C} ; \mathrm{R} 132755\right)$ and one stored in 100\% ethanol solution (R164785).

\section{Family Gekkonidae \\ Cyrtodactylus kimberleyensis Bauer \& Doughty, 2012}

Bauer, A.M. and Doughty, P. (2012) A new bent-toed gecko (Squamata: Gekkonidae: Cyrtodactylus) from the Kimberley region, Western Australia. Zootaxa 3187: 32-42 [34].

\section{Holotype}

R164144, 'East Montalivet Island, Kimberley region, WA (14 $\left.16^{\prime} \mathrm{S}, 125^{\circ} 18^{\prime} \mathrm{E}\right)$ ', R. Browne-Cooper, 26 April 2007.

\section{Remarks}

Liver sample of the holotype stored frozen $\left(-75^{\circ} \mathrm{C}\right)$ at WAM. 


\section{Gehyra capensis \\ Kealley, Doughty, Pepper, Keogh, Hillyer \& Huey, 2018}

Kealley, L., Doughty, P., Pepper, M., Keogh, S., Hillyer, M. and Huey, J. (2018) Conspicuously concealed: revision of the arid clade of the Gehyra variegata (Gekkonidae) species group in Western Australia using an integrative molecular and morphological approach, with the description of five cryptic species. PeerJ 6: e5334 [17/33].

\section{Holotype}

R117869, 'Vlaming Head, WA $\left(21^{\circ} 48^{\prime} \mathrm{S}, 114^{\circ} 06^{\prime} \mathrm{E}\right.$ (original coordinates, in ocean); $21.808^{\circ} \mathrm{S}, 114.111^{\circ} \mathrm{E}$ [21 $48^{\prime} 28^{\prime \prime S}, 114^{\circ} 06^{\prime} 39^{\prime \prime E}$ ] (estimate))', G. Harold and R.J. Teale, 3 January 2003.

\section{Paratypes (5)}

R153818, Vlaming Head, WA; R174300-02, Charles Knife Road, Cape Range NP, WA; R174316, ManduMandu Gorge, Cape Range NP, WA.

\section{Remarks}

Liver sample of holotype and two paratypes (R153818, $\mathrm{R} 174316)$ stored frozen $\left(-75^{\circ} \mathrm{C}\right)$ and three paratypes (R174300-02) stored in $100 \%$ ethanol solution at the WAM.

\section{Gehyra crypta \\ Kealley, Doughty, Pepper, Keogh, Hillyer \& Huey, 2018}

Kealley, L., Doughty, P., Pepper, M., Keogh, S., Hillyer, M. and Huey, J. (2018) Conspicuously concealed: revision of the arid clade of the Gehyra variegata (Gekkonidae) species group in Western Australia using an integrative molecular and morphological approach, with the description of five cryptic species. PeerJ 6: e5334 [19/33].

\section{Holotype}

R156482, 'Upper Marillana Creek, WA (22 ${ }^{\circ} 41^{\prime} \mathrm{S}$, 118 57'E)', M. Ladyman and colleagues, 15 April 2005.

\section{Paratypes (5)}

R111672, 1 km NNW Mount Bruce, WA; R117152, Dead Horse Rocks, 6.5 km N Menzies, WA; R151160, Tom Price, WA; R157121, West Angelas, WA; R165142, $2.1 \mathrm{~km}$ NNE Millstream, WA.

\section{Remarks}

Livers of holotype and four paratypes (R111672, R117152, R151160, R165142) and heart of one paratype (R117152) stored frozen $\left(-75^{\circ} \mathrm{C}\right)$ at WAM.

\section{Gehyra fenestra Mitchell, 1965}

Mitchell, F.J. (1965) Australian geckos assigned to the genus Gehyra Gray (Reptilia, Gekkonidae). Senckenbergiana Biologica 46: 287-319 [307].

\section{Holotype}

R20199, 'Mt. Herbert', WA [21ํㅇ'S, $\left.117^{\circ} 13^{\prime} E\right]$, F.J. Mitchell and W.H. Butler, 25 July 1958.

\section{Paratypes (4)}

R20198, R20201, Tambrey HS, WA; R20200, Big Hill Pool, Tambrey, WA; R20202, Mt Herbert, WA.

\section{Current status}

Junior synonym of Gehyra punctata, fide Storr (1982).

\section{Remarks}

Five additional paratypes held in the SAMA collection (SAMA R4596-97; SAMA R4601-02; SAMA R4600). Storr (1982) synonymised $G$. fenestra with $G$. punctata Fry, 1914; however, it was recognised as a distinct taxon by Cogger et al. (1983), further supported by Bauer and Henle (1994) who stated, 'we tentatively recognise $G$. fenestra as distinct'. See Doughty et al. (2018a) for the decision to maintain synonmy of G. fenestra with $G$. punctata based on the rediscovery of the missing syntype of the latter.

\section{Gehyra fenestrula Doughty, Bauer, Pepper \& Keogh, 2018}

Doughty, P., Bauer, A.M., Pepper, M. and Keogh, J.S. (2018a) Spots before the eyes: revision of the saxicoline geckos of the Gehyra punctata (Squamata: Gekkonidae) species complex in the Pilbara region of Western Australia. Records of the Western Australian Museum 33(1): 1-50 [24].

\section{Holotype}

R111769, 'Wheelarra Hill (PBS [Pilbara Biological Survey] site BDRS03), WA $\left(23.3586^{\circ} \mathrm{S}, 120.4590^{\circ} \mathrm{E}\right.$ [23⒉ $\left.21^{\prime} 30^{\prime \prime S}, 120^{\circ} 27^{\prime} 32^{\prime \prime E}\right]$ )', D. Pearson, K. Morris and M. Pepper, 2 October 2005.

\section{Paratypes (6)}

R71633, 21 km WSW Marillana HS, WA; R114337, 35 km SE Prarie Downs, WA; R125083, 15 km E Newman, WA; R127475, 32 km S Newman, WA; R129925, West Angelas, $100 \mathrm{~km}$ WNW Newman, WA; R135018, Mt Whaleback, WA.

\section{Remarks}

Liver sample of holotype and five paratypes (R114337, R125083, R127475, R129925, R135018) and heart of four paratypes (R114337, R125083, R127475, R129925) stored frozen $\left(-75^{\circ} \mathrm{C}\right)$ at WAM.

\section{Gehyra girloorloo Oliver, Bourke, Pratt, Doughty \& Moritz, 2016}

Oliver, P.M., Bourke, G., Pratt, R.C., Doughty, P. and Moritz, C. (2016) Systematics of small Gehyra (Squamata: Gekkonidae) of the southern Kimberley, Western Australia: redescription of G. kimberleyi Börner \& Schüttler, 1983 and description of a new restricted range species. Zootaxa 4107(1): 49-64 [56]. 


\section{Holotype}

R175045 (field no. CCM3257), 'Gogo Station, Pillara Range, south entrance of Menyous Gap, WA (18.40439 $\left.{ }^{\circ} \mathrm{S}, 125.83698^{\circ} \mathrm{E}\right)^{\prime}$ [ [18⒉ $\left.24^{\prime} 15^{\prime \prime S}, 125^{\circ} 50^{\prime} 13^{\prime \prime} \mathrm{E}\right]$, P.M. Oliver, G. Armstrong and P. Skipwith, 4 November 2014.

\section{Paratypes (6)}

R113727, Cadjbut Mine, 90 km SE Fitzroy Crossing, WA; R175037 (field no. PMO147), R175038 (field no. PMO149), $<1$ km S Galeru Gorge, WA; R175039 (field no. CCM3242), R175040 (field no. CCM3243), R175043 (field no. CCM3246), Limestone Billy Hills, Gogo Stn, WA.

\section{Remarks}

Four additional paratypes held in the NMV collection (NMV D77029-32, Ngumpan Cliff area, WA). Liver and heart sample of one paratype (R113727) stored frozen $\left(-75^{\circ} \mathrm{C}\right)$ at WAM.

\section{Gehyra granulum \\ Doughty, Palmer, Bourke, Tedeschi, Oliver \& Moritz, 2018}

Doughty, P., Bourke G., Tedeschi, L.G., Pratt, R.C., Oliver, P.M., Palmer, R.A. and Moritz, C. (2018b). Species delimitation in the Gehyra nana (Squamata: Gekkoidae) complex: cryptic and divergent morphological evolution in the Australian Monsoonal Tropics, with the description of four new species. Zootaxa 4403(2): 201-244 [220].

\section{Holotype}

R176212, 'Bell Gorge water hole, WA $\left(16.99333^{\circ} \mathrm{S}\right.$, $\left.125.20489^{\circ} \mathrm{E}\right)^{\prime}$ [16 $\left.{ }^{\circ} 59^{\prime} 35^{\prime \prime S}, 125^{\circ} 12^{\prime} 17^{\prime \prime E}\right]$, G. Bourke, J. Bragg, R. Laver and P. Title, 22 May 2013.

\section{Paratypes (8)}

R158823, Bigge Is, WA; R168558 (field no. BP01286), Champagny Is, WA; R168561 (field no. BP01272), Byam Martin Is, WA; R171072 (field no. BP00315), Augustus Is, WA; R171403, Bachsten Creek bush camp, WA; R171426, Prince Regent River NP, WA; R176224 (formerly CCM1339), Gibb River Road, WA; R176245 (formerly CCM1492), Gibb River Road, WA.

\section{Remarks}

Two additional paratypes held at NMV (NMV D75774 and D75778). Liver sample of five paratypes stored in 100\% ethanol (R168558, R168561, R171072, R171403, $\mathrm{R} 171426)$ and one stored frozen $\left(-75^{\circ} \mathrm{C}\right)(\mathrm{R} 158823)$ at the WAM.

\section{Gehyra incognita Kealley, Doughty, Pepper, Keogh, Hillyer \& Huey, 2018}

Kealley, L., Doughty, P., Pepper, M., Keogh, S., Hillyer, M. and Huey, J. (2018) Conspicuously concealed: revision of the arid clade of the Gehyra variegata (Gekkonidae) species group in Western Australia using an integrative molecular and morphological approach, with the description of five cryptic species. PeerJ 6: e5334 [24/33].

\section{Holotype}

R161379, '38 km north-north-west of Marble Bar, site PHYC06 of the Pilbara Biodiversity Survey, WA $\left(20^{\circ} 50^{\prime} 07^{\prime \prime S}, 119^{\circ} 40^{\prime} 18^{\prime \prime E}\right)^{\prime}$, A.H. Burbidge and C. Stephenson, 26 September 2005.

\section{Paratypes (5)}

R145629, 18 km S Port Hedland, WA; R156815, Port Hedland area, WA; R159848, $12.5 \mathrm{~km} \mathrm{~S}$ Whim Creek Hotel, WA; R165149, 5 km NNE Python Pool, WA; R166629, Mons Cupri Mine, WA.

\section{Remarks}

Liver sample of holotype and all five paratypes stored frozen $\left(-75^{\circ} \mathrm{C}\right)$ at WAM.

\section{Gehyra koira ipsa Horner, 2005}

Horner, P. (2005) Gehyra koira sp. nov. (Reptilia: Gekkonidae), a new species of lizard with two allopatric subspecies from the Ord-Victoria region of north-western Australia and a key to the Gehyra australis species complex. The Beagle, Records of the Museums and Art Galleries of the Northern Territory 21: $165-174$ [171].

\section{Holotype}

R101238, 'Piccaninny Massif, Purnululu (Bungle Bungle) National Park, WA (17 $\left.27^{\prime} \mathrm{S}, 128^{\circ} 24^{\prime} \mathrm{E}\right)$ ', N. Gambold, 25 August 1989.

\section{Paratypes (11)}

R101237, R101239* (now NTM R28099), Picaninny Massif, Purnululu (Bungle Bungle) NP, WA; R10428384, Frog Hole Gorge, Purnululu (Bungle Bungle) NP, WA; R104285* (now NTM R28098), R10429091, Echidna Chasm, Purnululu (Bungle Bungle) NP, WA; R104286, R104288, R104295, Piccaninny Gorge, Purnululu (Bungle Bungle) NP, WA; R104289, Wulwuldji Spring, Purnululu (Bungle Bungle) NP, WA.

\section{Remarks}

Two paratypes (R101239 and R104285) were gifted to the NTM on 19 May 2006, now registered as NTM R28099 and R28098, respectively.

\section{Gehyra koira koira Horner, 2005}

Horner, P. (2005) Gehyra koira sp. nov. (Reptilia: Gekkonidae), a new species of lizard with two allopatric subspecies from the Ord-Victoria region of north-western Australia and a key to the Gehyra australis species complex. The Beagle, Records of the Museums and Art Galleries of the Northern Territory 21: 165-174 [168].

\section{Paratypes (3)}

R108446 (formerly NTM R10520), Keep River NP, NT; R108447 (formerly NTM R22462), Limestone 
Gorge, Gregory NP, NT; R108448 (formerly NTM R24253), Fitzmaurice River, Bradshaw Stn, NT.

\section{Remarks}

All three paratypes were formerly held in the NTM collection, gifted to WAM by Horner in 2006. Holotype held in the NTM collection, NTM R22406 from 'Nganlang Art Site, Keep River National Park, NT (1548'26"S, $\left.129^{\circ} 06^{\prime} 23^{\prime \prime E}\right)^{\prime}$, collected by P. Horner, 27 April 1996.

\section{Gehyra macra \\ Doughty, Bauer, Pepper \& Keogh, 2018}

Doughty, P., Bauer, A.M., Pepper, M. and Keogh, J.S. (2018a) Spots before the eyes: revision of the saxicoline geckos of the Gehyra punctata (Squamata: Gekkonidae) species complex in the Pilbara region of Western Australia. Records of the Western Australian Museum 33(1): 1-50 [17].

\section{Holotype}

R162703, 'Baldy Rock, WA $\left(21.05^{\circ} \mathrm{S}, 118.80^{\circ} \mathrm{E}\right.$ [21 $03^{\prime}$ S, $\left.\left.118^{\circ} 48^{\prime} \mathrm{E}\right]\right)$ ', P. Dougthy, C.A. Stevenson and P.G. Kendrick, 17 May 2006.

\section{Paratypes (11)}

R154517, Yarrie Mining Camp, WA; R156587, R160096-98, 13 km SE Braeside, WA; R162688, R162701-02, Baldy Rock, WA; R173363, Roy Hill Rail chainage 76, $65 \mathrm{~km}$ S South Hedland; R173364, R173366, Roy Hill Rail chainage 75, 67 km S South Hedland, WA.

\section{Remarks}

Liver of holotype and eight paratypes (R154517, R156587, R160096-98, R162688, R162701-02) stored frozen $\left(-75^{\circ} \mathrm{C}\right)$ and liver sample of three paratypes (R173363-64, R173366) stored in 100\% ethanol solution at the WAM.

\section{Gehyra media \\ Doughty, Bauer, Pepper \& Keogh, 2018}

Doughty, P., Bauer, A.M., Pepper, M. and Keogh, J.S. (2018a) Spots before the eyes: revision of the saxicoline geckos of the Gehyra punctata (Squamata: Gekkonidae) species complex in the Pilbara region of Western Australia. Records of the Western Australian Museum 33(1): 1-50 [27].

\section{Holotype}

R162687, 'Baldy Rock, Pilbara region, WA $\left(21.05^{\circ} \mathrm{S}\right.$, $\left.118.80^{\circ} \mathrm{E}\left[21^{\circ} 03^{\prime} \mathrm{S}, 118^{\circ} 48^{\prime} \mathrm{E}\right]\right)^{\prime}$, P. Doughty, C.A. Stevenson and P.G. Kendrick, 15 May 2006.

\section{Paratypes (5)}

R160940, 9 km NW Lake Poongkaliyarra, WA; R161014, 3.5 km S Marda Pool, WA; R162686, R162704, Baldy Rock, WA; R174289, Nanutarra Roadhouse, WA.

\section{Remarks}

Liver sample of holotype four paratypes (R160940, $\mathrm{R} 161014, \mathrm{R} 162686, \mathrm{R} 162704)$ stored frozen $\left(-75^{\circ} \mathrm{C}\right)$ and liver sample of one paratype (R174289) stored in $100 \%$ ethanol solution at the WAM.

\section{Gehyra micra Doughty, Bauer, Pepper \& Keogh, 2018}

Doughty, P., Bauer, A.M., Pepper, M. and Keogh, J.S. (2018a) Spots before the eyes: revision of the saxicoline geckos of the Gehyra punctata (Squamata: Gekkonidae) species complex in the Pilbara region of Western Australia. Records of the Western Australian Museum 33(1): 1-50 [29].

\section{Holotype}

R165158, '3.5 km N Karratha Station (PBS [Pilbara Biological Survey] site DRW05), WA $\left(20.8539^{\circ} \mathrm{S}\right.$, $\left.116.669^{\circ} \mathrm{E}\left[20^{\circ} 51^{\prime} 14^{\prime S} \mathrm{~S}, 116^{\circ} 40^{\prime} 08^{\prime \prime E}\right]\right)^{\prime}$, P. Doughty and L. Gibson, 17 May 2005.

\section{Paratypes (6)}

R110011, 6 km NW Roebourne, WA; R110013, 5 km S Lake Poongkaliyarra, WA; R110045, R110073, 13.5 km W Wickham, WA; R125029, Yandicoogina, WA; R160879, 3.5 km S Marda Pool, WA.

\section{Remarks}

Liver sample of holotype and all six paratypes and heart of one paratype (R125029) stored frozen $\left(-75^{\circ} \mathrm{C}\right)$ at WAM.

\section{Gehyra montium Storr, 1982}

Storr, G.M. (1982) Two new Gehyra (Lacertilia: Gekkonidae) from Australia. Records of the Western Australian Museum 10(1): 53-59 [56].

\section{Holotype}

R31732, 'Mt Lindsay, SA (2702'S, $\left.129^{\circ} 53^{\prime} \mathrm{E}\right)$ ', G.M. Storr, J.R. Ford and P.J. Fuller, 29 August 1968.

\section{Paratypes (76)}

R20715-23, Barrow Range, WA; R20730-33, Cavenagh Range, WA; R20944, Cave Hill, Musgrave Ranges, SA; R20967, Piltadi Rockhole, Mann Ranges, SA; R20981-87, R34149, Blackstone Pass, WA; R22028, R22032, Warburton Range, WA; R24296-99, R24301, Devils Marbles, $12 \mathrm{~km} \mathrm{~N}$ Wauchope, NT; R31692, Hinckley Range, WA; R31698-700, 8 km NW Mt Davies Camp, SA; R31712, 18 km S Mt Davies Camp, SA; R31721-23, Krewinkel Hill, SA; R31728, 28 km Mt Lindsay, SA; R31733-66, R44364-65, Mt Lindsay, SA; R54289, 2 km E Emily Gap, NT. 


\section{Gehyra multiporosa \\ Doughty, Palmer, Sistrom, Bauer \& Donnellan, 2012}

Doughty, P., Palmer, R., Sistrom, M.J., Bauer, A.M. and Donnellan, S.C. (2012) Two new species of Gehyra (Squamata: Gekkonidae) geckos from the north-west Kimberley region of Western Australia. Records of the Western Australian Museum 27: 117-134 [128].

\section{Holotype}

R167804, 'Surveyors Pool, Mitchell Plateau, WA

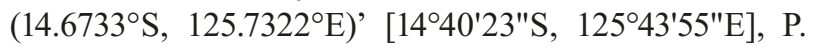
Doughty and C.A. Stevenson, 9 January 2007.

\section{Paratypes (6)}

R167890, Mitchell Plateau, WA; R168177, Boongaree Is, WA; R168577, Augustus Is, WA; R168584, Byam Martin Is, WA; R171491, R171547, Prince Regent River NR [NP], WA.

\section{Remarks}

Liver of holotype and three paratypes (R167890, R168577 and R168584) stored in 100\% ethanol at WAM.

\section{Gehyra nana Storr, 1978}

Storr, G.M. (1978a) Seven new gekkonid lizards from Western Australia. Records of the Western Australian Museum 6(3): 337-352 [347].

\section{Holotype}

R28214, 'King Edward River, WA (presumably in $\left.14^{\circ} 52^{\prime} \mathrm{S}, 126^{\circ} 12^{\prime} \mathrm{E}\right)^{\prime}$, A.K. Lee, 8 June 1965.

\section{Paratypes (94)}

R27750 [in error, R27550], R27751-52 [in error, R27551-52], R27757-62 [in error, R27557-62], R56639 [in error, R56839], Kalumburu, WA; R28187, R28213, R28215-18, King Edward River, WA; R40441, Augustus Is, WA; R40469* (now MCZ R158546), R40470* (now MCZ R158547), R40471* (now MCZ R158548), R43147, R43157, Mitchell Plateau, WA; R41391, Darcy Is, WA; R41371-72, Heywood Is, WA; R41428-31, Champagne Is, WA; R41455, Bigge Is, WA; R42704, 13 km NNE Argyle Downs, WA; R43062-63, R43079-81, R56167, R56211, R56212, Crystal Creek, WA; R43559-62, Pago, WA; R44051-55, R44065-66, Sir Graham Moore Is, WA; R44075, Anjo Point; R44088, Boongaree Is, WA; R44110, South-west Osborne Is, WA; R44144, St Andrew Is, WA; R44157-65, Kingfisher Is, WA; R44195 [in error, R44195A (now R99543)], Melomys Is, WA; R46668-72, R46706-07, R46710 [in error, R47010], R46883, R46884, R46831-32, R46837-38, Prince Regent River NR [NP], WA; R50330-32, R50400-03, R50414, R50465, R50507, R50675, R50783, R50797, R50802, R50811, Drysdale River NP, WA; R56357, $2 \mathrm{~km} \mathrm{E} \mathrm{of}$ Mitchell River Falls, WA.

\section{Remarks}

Registration numbers for 12 paratypes presented by Storr are in error; R27750 is a specimen of Tiliqua scincoides, R27750-52 and R27757-59 are specimens of Cyclodomorphus melanops melanops, R27760 is a specimen of Cyclodomorphus maximus, R27761-62 are specimens of Egernia stokesii badia, R44195 is a specimen of Hydrophis ornatus, R46710 is a specimen of Liasis burtonis and R56639 is a specimen of Lerista kingi. The correct registrations for specimens matching the collection localities presented by Storr are R27550-52, R27557-62, R47010, R56839, and R44195A (now R99543). Examination of early registration catalogues revealed two entries associated with the number R44195; one part of a series (R44194-95) and a second suffixed with an A (R44195A); however, Storr referred to R44195 only. The entry for R44195 is entered as 'Hydrophis ocellatus' from 'near Sunday Island, Exmouth Gulf, WA', collected August 1973 and R44195A entered as "Gehyra 'punctata" from Melomys Island (original entry stated 'South Wood Island, Collier Bay, WA' with South Wood crossed our and 'Melomys I' written above it, collected 12 July 1973. The second entry (R44195A) is annotated with 'Now 99543 Las [Laurie A. Smith] 17/5/88'.

Thirty-three paratypes have been identified as other Gehyra species; 13 are G. granulum (R40441, R4137172, R41428-31，R44088，R46668，R46672, R50783, R56167, R56211), 10 are G. occidentalis (R44157-65, R99543), nine are G. multiporosa (R41391, R41455, R44144, R46883-84, R46831-32, R46837-38) and one G. koira koira (R50402) (Doughty et al. 2018b). Three paratypes were gifted to MCZ on 17 December 1979 (R40469-71, now MCZ R158546-48).

\section{Gehyra ocellata Kealley, Doughty, Pepper, Keogh, Hillyer \& Huey, 2018}

Kealley, L., Doughty, P., Pepper, M., Keogh, S., Hillyer, M. and Huey, J. (2018) Conspicuously concealed: revision of the arid clade of the Gehyra variegata (Gekkonidae) species group in Western Australia using an integrative molecular and morphological approach, with the description of five cryptic species. PeerJ 6: e5334 [24/33].

\section{Holotype}

R173013, 'Barrow Island, WA (2047'46"S, $\left.115^{\circ} 25^{\prime} 52^{\prime \prime E}\right)^{\prime}$, S. Schmidt, 11 December 2012.

\section{Paratypes (6)}

R165741, Barrow Is, WA; R165971, Trimouille Is, WA; R165973-75, Hermite Island, WA; R172939, WAPET Barge Landing, Barrow Is, WA. 


\section{Remarks}

Kealley et al. list only five specimens under Paratypes; however, a sixth specimen (R165741) is presented in Figure 7 (p. 23/33) with the figure caption 'Variation among preserved Gehyra ocellata sp. nov. specimens. (A) Holotype specimen, (B) paratype specimens...' As this specimen contributed to the description and variation of the species it is considered a paratype. Of the five specimens listed under Paratypes, one is not shown in Figure 7 which only shows five paratype specimens (R165971). Liver sample of holotype and all six paratypes stored frozen $\left(-75^{\circ} \mathrm{C}\right)$ at WAM.

\section{Gehyra occidentalis King, 1984}

King, M. (1984a) A new species of Gehyra (Reptilia: Gekkonidae) from northern Western Australia. Transactions of the Royal Society of South Australia 108(2): 113-117 [114].

\section{Holotype}

R83711, 'Manning Gorge, WA (16 $\left.44^{\prime} \mathrm{S}, 125^{\circ} 57^{\prime} \mathrm{E}\right)$ ', D.R. King, 3 July 1980.

\section{Paratypes (9)}

R45009, Napier Range, WA; R58757-59, Wombarella Creek, Napier Downs, WA; R70553, R70664, 8.6 km SE Mt Amy, Napier Downs, WA; R70587, $11.5 \mathrm{~km}$ SE Mt Percy, WA; R83712-13, $32 \mathrm{~km}$ E of turnoff to Napier Downs on Gibb River Rd, WA.

\section{Remarks}

One paratype, R83712 has been identified as a specimen of Gehyra multiporosa by Doughty et al. (2012).

\section{Gehyra paranana Bourke, Doughty, Tedeschi, Oliver \& Moritz, 2018}

Doughty, P., Bourke G., Tedeschi, L.G., Pratt, R.C., Oliver, P.M., Palmer, R.A. and Moritz, C. (2018b). Species delimitation in the Gehyra nana (Squamata: Gekkoidae) complex: cryptic and divergent morphological evolution in the Australian Monsoonal Tropics, with the description of four new species. Zootaxa 4403(2): 201-244 [215].

\section{Paratype}

R177563 (field no. CCM2937), Florence Falls turnoff, Litchfield National Park, NT.

\section{Remarks}

Holotype held at NTM, NTM R37057, from 'Dorat Road, Robin Falls area, NT (13.35278 $\left.{ }^{\circ} \mathrm{S}, 131.13361^{\circ} \mathrm{E}\right)$ ' [132 $\left.21^{\prime} 10^{\prime \prime S}, 131^{\circ} 08^{\prime} 01^{\prime \prime E}\right]$ by P.M. Oliver, P. Skipworth and M. Hammer, 21 September 2013. Eleven additional paratypes held at NTM (NTM R20246, R36554, R36578-79, R37056, R37831 (formerly CCM0651), R37832 (formerly CCM0652), R37833 (formerly CCM2881), R37834 (formerly CCM2883), R37835 (formerly CCM2885) and R37836 (formerly CCM2936)).

\section{Gehyra peninsularis \\ Doughty, Bauer, Pepper \& Keogh, 2018}

Doughty, P., Bauer, A.M., Pepper, M. and Keogh, J.S. (2018a) Spots before the eyes: revision of the saxicoline geckos of the Gehyra punctata (Squamata: Gekkonidae) species complex in the Pilbara region of Western Australia. Records of the Western Australian Museum 33(1): 1-50 [31].

\section{Holotype}

R165749, 'Dampier Port, Burrup Peninsula, WA (2037'S, 116 $\left.\left.45^{\prime} \mathrm{E}\right]\right)^{\prime}$, G. Harold and L. Beesley, 26 April 2006.

\section{Paratypes (5)}

R132562, R146581, Burrup Peninsula, WA; R165239, $2.4 \mathrm{~km} \mathrm{~W}$ Hearson Cove, Burrup Peninsula, WA; R165240, 3.4 km NE Dampier, Burrup Peninsula, WA; R165748, Dampier Port, Burrup Peninsula, WA.

\section{Remarks}

Liver sample of holotype and all five paratypes stored frozen $\left(-75^{\circ} \mathrm{C}\right)$ at WAM.

\section{Gehyra pilbara Mitchell, 1965}

Mitchell, F.J. (1965) Australian geckos assigned to the genus Gehyra Gray (Reptilia, Gekkonidae). Senckenbergiana Biologica 46: 287-319 [303].

\section{Holotype}

R20046, 'Tambrey, on the Pilbara Plateau, WA' [21 $38^{\prime}$ S, $\left.117^{\circ} 36^{\prime} \mathrm{E}\right]$, F.J. Mitchell and W.H. Butler, collected between 28 July and 3 August 1958.

\section{Paratypes (41) \\ R20026-45, R20047-67, Tambrey, WA.}

\section{Remarks}

The allotype specimen (R20040) listed by Mitchell was excluded from the list of designated paratype specimens in the description due to its allotype status; however, the specimen is maintained with the paratype specimens in the WAM type collection, as allotypes have no special standing under the rules of nomenclature. An additional 41 paratypes are held in other collections: 37 at SAMA (SAMA R4433-69) and four at SMF (SMF 60040-43).

\section{Gehyra pluraporosa \\ Bourke, Doughty, Tedeschi, Oliver, Myers \& Moritz, 2018}

Doughty, P., Bourke G., Tedeschi, L.G., Pratt, R.C., Oliver, P.M., Palmer, R.A. and Moritz, C. (2018b). Species delimitation in the Gehyra nana (Squamata: Gekkoidae) complex: cryptic and divergent morphological evolution in the Australian Monsoonal Tropics, with the description of four new species. Zootaxa 4403(2): 201-244 [224]. 


\section{Holotype}

R174024, 'King Edward River, WA (14.75373 ${ }^{\circ}$ S, $\left.126.21050^{\circ} \mathrm{E}\right)^{\prime}$ [14² $\left.45^{\prime} 13^{\prime \prime S}, 126^{\circ} 12^{\prime} 37^{\prime \prime E}\right]$, Doughty, P., Ellis, R.J. and Catullo, R., 7 March 2014.

\section{Paratypes (4)}

R174026, King Edward River, WA; R176170 (formerly CCM0918), King Edward River, 30 km N Theda Stn HS, WA; R176372 (formerly CCM5962), R176373 (formerly CCM5963), Bruce's Creek, Theda Stn, WA.

\section{Remarks}

Liver sample of holotype stored in $100 \%$ ethanol at the WAM.

\section{Gehyra polka \\ Doughty, Bauer, Pepper \& Keogh, 2018}

Doughty, P., Bauer, A.M., Pepper, M. and Keogh, J.S. (2018a) Spots before the eyes: revision of the saxicoline geckos of the Gehyra punctata (Squamata: Gekkonidae) species complex in the Pilbara region of Western Australia. Records of the Western Australian Museum 33(1): 1-50 [22].

\section{Holotype}

R132290, " $6 \mathrm{~km}$ north-west of Noondie Outstation, WA $\left(27.0744^{\circ} \mathrm{S}, 117.0789^{\circ} \mathrm{E}\left[27^{\circ} 04^{\prime} 27^{\prime} \mathrm{S}, 117^{\circ} 04^{\prime} 44^{\prime \prime} \mathrm{E}\right]\right)$, B. Maryan, 11 April 1998.

\section{Paratypes (7)}

R119368-69, 50 km SW Yalgoo, WA; R127414-15, $10.3 \mathrm{~km}$ S Yinnietharra HS, WA; R127543, Barnong HS, WA; R132291, 6 km NW Noondie OS, WA; R132294, Marlandy Hill, WA.

\section{Remarks}

Liver sample of holotype and six paratypes (R119368, R127414-15, R127543, R132291, R132294) and heart of three (R127414-15, R127543) stored frozen $\left(-75^{\circ} \mathrm{C}\right)$ at WAM.

\section{Gehyra pseudopunctata Doughty, Bourke, Tedeschi, Oliver \& Moritz, 2018}

Doughty, P., Bourke G., Tedeschi, L.G., Pratt, R.C., Oliver, P.M., Palmer, R.A. and Moritz, C. (2018b). Species delimitation in the Gehyra nana (Squamata: Gekkoidae) complex: cryptic and divergent morphological evolution in the Australian Monsoonal Tropics, with the description of four new species. Zootaxa 4403(2): 201-244 [217].

\section{Holotype}

R164776, 'Mt Nyulasy, WA $\left(16.74527^{\circ} \mathrm{S}\right.$, $128.28250^{\circ} \mathrm{E}$ )' [16 $\left.46^{\circ} 42^{\prime \prime S}, 128^{\circ} 16^{\prime} 57^{\prime \prime E}\right]$, P. Doughty, P.M. Oliver and D. Moore, 17 January 2008.

\section{Paratypes (9)}

R70554, 9 km SSE Mt Amy, WA; R132856, 10 km S Bow River Stn, WA; R151018, R164777-78, R176304 (formerly CCM3085), Mt Nyulasy, WA; R172099 (field no. BP02080), Windjana Gorge, WA; R176238 (formerly CCM1440), Sir John Gorge, Mornington [Stn], WA; R176242 (formerly CCM1464), Teronis Gorge, Tableland [Stn], WA.

\section{Remarks}

One additional paratype held at NMV (NMV D77003). Liver sample of holotype and two paratypes (R164777-78) stored in 100\% ethanol and two stored frozen $\left(-75^{\circ} \mathrm{C}\right)(\mathrm{R} 132856, \mathrm{R} 151018)$ stored at the WAM. In the paratypes heading, Doughty et al. (2018b) state '(9)' specimens; however, 10 registrations are listed below, nine from WAM and one from NMV.

\section{Gehyra pulingka Hutchinson, Sistrom, Donnellan \& Hutchinson, 2014}

Hutchinson, M.N., Sistrom, M.J., Donnellan, S.C. and Hutchinson, R.G. (2014) Taxonomic revision of the Australian arid zone lizards Gehyra variegata and $G$. montium (Squamata, Gekkonidae) with description of three new species. Zootaxa 3814(2): 221-241 [238].

\section{Paratype}

R166314, Kurtjurntari Rockhole, WA.

\section{Remarks}

Holotype held in the SAMA collection, SAMA R65248, 'Umuwa, Musgrave Ranges, SA (26²8'45"S, $113^{\circ} 57^{\prime} 02^{\prime \prime E)}$ ', collected by M. Hutchinson, 26 May 2010. An additional 15 paratypes held in the SAMA collection (SAMA R28265, R28322-23, R41876-77, R42069, R44892, R50119, R51536-37, R51540, R51565, R51574, R54751, R61926). Liver sample of WAM paratype stored at EBU.

\section{Gehyra punctulata Doughty, Bauer, Pepper \& Keogh, 2018}

Doughty, P., Bauer, A.M., Pepper, M. and Keogh, J.S. (2018a) Spots before the eyes: revision of the saxicoline geckos of the Gehyra punctata (Squamata: Gekkonidae) species complex in the Pilbara region of Western Australia. Records of the Western Australian Museum 33(1): 1-50 [19].

\section{Holotype}

R139194, 'Mount Minnie, WA $\left(22.2650^{\circ} \mathrm{S}, 115.4072^{\circ} \mathrm{E}\right.$ [22 $\left.15^{\prime} 54^{\prime \prime S}, 115^{\circ} 24^{\prime} 25^{\prime \prime E}\right]$ )', P.G. Kendrick, 26 June 2000.

\section{Paratypes (6)}

R113599, R113633, 30 km ENE Nanutarra, WA; R117038，R117040，18 km W Mt Stuart HS, WA; R131769, Muggon Stn, WA; R163106, 19.5 km SSW Mt Amy, WA.

\section{Remarks}

Liver sample of holotype and all six paratypes and heart of four paratypes (R113599, R113633, R117038, $\mathrm{R} 117040)$ stored frozen $\left(-75^{\circ} \mathrm{C}\right)$ at WAM. 


\section{Gehyra purpurascens Storr, 1982}

Storr, G.M. (1982) Two new Gehyra (Lacertilia: Gekkonidae) from Australia. Records of the Western Australian Museum 10(1): 53-59 [53].

\section{Holotype}

R72660, '3.5 km NE of Comet Vale, WA $\left(29^{\circ} 55^{\prime} \mathrm{S}\right.$, $\left.121^{\circ} 08^{\prime} \mathrm{E}\right)$ ', A.V. Milewski, 6 October 1980.

\section{Paratypes (107)}

R13103a (now R13103), $138 \mathrm{~km}$ NE Laverton, WA; R15702, Mt Eveline, WA; R16480-81, R21015, R21018, R21020, R22029-31, Warburton Range, WA; R20753, Pass of the Abencerrages, Rawlinson Range, WA; R20771, Docker River, NT; R20927, 35 km W Victory Downs, NT; R20992-98, Winburn Rocks, WA; R21039, 12 km SE Mt Beadell, Gibson Desert, WA; R21195-97, White Cliffs, WA; R21381, Tennant Creek, NT; R2139495, $10 \mathrm{~km}$ E Tennant Creek, NT; R24185, Elliott, NT; R24293-94, 23 km N Wauchope, NT; R24375-77, 26 km NE Teatree, NT; R24466, 8 km SW Deep Well RS, NT; R26883-84, 56 km NE Carnegie, WA; R26961, 8 km NW Gary Junction, WA; R28867, 207 km ENE Carnegie, WA; R29382, Swindell Field, WA; R31702, Mt Davies Camp, SA; R31909, R41578, 70 km N Neale Junction, WA; R34635-36, 10 km N Wauchope, NT; R36606, 10 km E Vokes Hill, SA; R37498, 64 km Skipper Knob, WA; R40152, 65 km E Jupiter Well, WA; R40157, Well 35, Canning Stock Route, WA; R40175, R45173-74, R45176, R57068, Pollock Hills, WA; R40598, 65 km NE Carnegie, WA; R41579, 96 km N Neale Junction, WA; R45115, 72 km W Terry Range, WA; R45210-13, 36 km E Jupiter Well, WA; R45221-22, 7 km E Terry Range, WA; R45225-26, 60 km N Windy Corner, WA; R46049, 26 km NE Mclarty Hills, WA; R46087-88, 21 km NNE Mclarty Hills, WA; R47679, 92 km S Balgo Mission, WA; R48342, R48359, 48 km N Beacon, WA; R48777, 35 km N Neale Junction, WA; R51935, Durba Spring, WA; R51950, Well 11, Canning Stock Route, WA; R53336-39, 27 km NE White Cliffs, WA; R53536-39, 27 km E Point Sunday, WA; R57253, 15 km W Dakota Hills, WA; R58728, Queen Victoria Spring, WA; R63209, 33 km NE Bulgamulgardy Soak, WA; R63767, 14 km SE Miles Hill, WA; R63844, 37 km SE Gargoonyah Waterhole, WA; R63905-06, R63916-17, Well 24, Canning Stock Route, WA; R65799, 3.5 km NE Comet Vale, WA; R66039, 9 km SSE Banjawarn, WA; R69245-47, R69249-53, R6931314, R74756, R74792, 13 km SE Banjawarn, WA; R72595, 50 km E Comet Vale, WA; R73912, 23 km ENE Cosmo Newbery, WA; R74019, Renner Springs, NT.

\section{Remarks}

In the original description, under 'Paratypes' Storr stated 118 specimens held in WAM from WA, SA and NT, listed under 'Material'; however, only 107 specimens are listed there. One specimen listed as a paratype by Storr, R13103a, is now registered as R10103. The original registration catalogue entry for R10103, accessioned 15 June 1959, was for a specimen listed as Amphibolurus reticulatus major from Peterman Ranges, WA, with reticulatus major crossed out and inermis written above it. In the remarks column of the registration entry, there is an undated annotation stating '2 specimens' followed by 'R13103 = G. purpurascens (10103a of Storr 19822 new Gehyra...)' and ' R94786 $=G$. variegata' below it in braces. No Ctenophorus specimens bearing the registration number R10103 could be located within the collection and the specimen associated with the original entry is presumed lost, with the registration number having subsequently been reused for the Gehyra purpurascens specimen.

\section{Gehyra spheniscus Doughty, Palmer, Sistrom, Bauer \& Donnellan, 2012}

Doughty, P., Palmer, R., Sistrom, M.J., Bauer, A.M. and Donnellan, S.C. (2012) Two new species of Gehyra (Squamata: Gekkonidae) geckos from the north-west Kimberley region of Western Australia. Records of the Western Australian Museum 27: 117-134 [126].

\section{Holotype}

R171591, 'Lower Monjon Rocks, Prince Regent River Nature Reserve [National Park], WA $\left(15.9775^{\circ} \mathrm{S}\right.$, $\left.125.3678^{\circ} \mathrm{E}\right)^{\prime}\left[15^{\circ} 58^{\prime} 39^{\prime \prime S}, 125^{\circ} 22^{\prime} 04^{\prime \prime E}\right.$, C.A. Stevenson and R. Somaweera, 25 January 2010.

\section{Paratypes (6)}

R167810, Surveyors Pool, Mitchell Plateau, WA; R168715, Katers Is, WA; R171402, R171434, R171460, Prince Regent River NR [NP], WA; R171570, Old Beverley Spring Rd, $25 \mathrm{~km}$ S Prince Regent River NR [NP], WA.

\section{Gehyra unguiculata \\ Kealley, Doughty, Pepper, Keogh, Hillyer \& Huey, 2018}

Kealley, L., Doughty, P., Pepper, M., Keogh, S., Hillyer, M. and Huey, J. (2018) Conspicuously concealed: revision of the arid clade of the Gehyra variegata (Gekkonidae) species group in Western Australia using an integrative molecular and morphological approach, with the description of five cryptic species. PeerJ 6: e5334 [26/33].

\section{Holotype}

R161461, ‘47.5 km east-south-east of Goldsworthy, site PHYC03 of the Pilbara Biodiversity Survey, WA $\left(20^{\circ} 25^{\prime} 41^{\prime \prime S}, 119^{\circ} 58^{\prime} 10^{\prime \prime E}\right)^{\prime}$, A.H. Burbidge and C. Stephenson, 1 October 2005.

\section{Paratypes (5)}

R108368, Sunrise Hill, WA; R108420, Nimingarra, WA; R156584, Cundaline Gap, WA; R161459-60, 47.5 km ESE Goldsworthy, WA.

\section{Remarks}

Liver of holotype and three paratypes (R156584, R161459-60) stored frozen $\left(-75^{\circ} \mathrm{C}\right)$ at WAM. 


\section{Gehyra xenopus Storr, 1978}

Storr, G.M. (1978a) Seven new gekkonid lizards from Western Australia. Records of the Western Australian Museum 6(3): 337-352 [349].

Holotype

R56429, 'near the Port Warrender road crossing of the King Edward River, WA (14 $52^{\prime}$ S, $\left.126^{\circ} 12^{\prime} \mathrm{E}\right)^{\prime}$, R.E. Johnstone, 6 November 1976.

\section{Paratypes (58)}

R27753 [in error, R27553*], R27754 [in error, R27554*], R27755 [in error, R27555* (now MCZ R158549)], Kalumburu, WA; R41283-84, Augustus Is, WA; R41392-96, Darcy Is, WA; R41432-33, Champagny Is, WA; R41463, Wollaston Is, WA; R41468-70, Katers Is, WA; R41488, Borda Is, WA; R43042-43，R43069-70，R56163-66，R56180-81, Crystal Creek, WA; R43177, R56356, R56417, 2 km E Mitchell River Falls, WA; R44077, Bat Is, off Cape Brewster, WA; R44086-87, Boongaree Is, WA; R44107-09, R44111, R44126, South-west Osborne Is, WA; R44136, Uwins Is, WA; R44143, St Andrew Is, WA; R44152-53, Byam Martin Is, WA; R46775-77, R46779-80, R46796-98, R46818-19, R46822, R46830, R46986-87, Prince Regent River NR [NP], WA; R56428, R56430, King Edward River, WA.

\section{Heteronota spelea Kluge, 1963}

Kluge, A.G. (1963b) A review of the gekkonid lizard genus Heteronota Gray, with a description of a new species from Western Australia. Journal of the Royal Society of Western Australia 46: 63-67 [64].

\section{Holotype}

R12638, 'Prophecy West mine at Bamboo Creek, Marble Bar District, WA' [2052'S, $\left.120^{\circ} 10^{\prime} \mathrm{E}\right]$, A. Douglas and W.D.L. Ride, 12-13 October 1957.

\section{Paratypes (2)}

R12639-40, Bamboo Creek, WA.

\section{Current nomenclature}

Heteronotia spelea, see Wermuth (1965).

\section{Heteronotia atra \\ Pepper, Doughty, Fujita, Moritz \& Keogh, 2013}

Pepper, M., Doughty, P., Fujita, M.K., Moritz, C. and Keogh, J.S. (2013) Speciation on the rocks: Integrated systematics of the Heteronotia spelea species complex (Gekkota; Reptilia) from Western and central Australia. PLoS ONE 8(11): e78110.

\section{Holotype}

R110076, '5 km south of Lake Poongkaliyarra, WA $\left(-21.03590^{\circ} \mathrm{S}, 117.10658^{\circ} \mathrm{E}\right){ }^{\prime}$ [ [21 $\left.02^{\circ} 09^{\prime \prime S}, 117^{\circ} 06^{\prime} 23^{\prime \prime} \mathrm{E}\right]$, J.K. Rolfe, L.A. Smith and B. Durrant, 10 October 2004.

\section{Paratypes (5)}

R110056, R110075, R162439, R165222, 5 km S Lake Poongkaliyarra, WA; R163243, 12.8 km SW Roebourne, WA.

\section{Remarks}

Liver sample of holotype and all paratypes stored frozen $\left(-75^{\circ} \mathrm{C}\right)$ at WAM.

\section{Heteronotia planiceps Storr, 1989}

Storr, G.M. (1989) A new Heteronotia (Lacertilia: Gekkonidae) from Western Australia. Records of the Western Australian Museum 14(3): 269-273 [269].

\section{Holotype}

R96971, '15 km SW Kings Cascade, WA (1543'S, 125¹2'E)', R.E. Johnstone, 18 June 1987.

\section{Paratypes (40)}

R26767, Windjana Gorge, WA; R26768, 38 km SE Halls Creek, WA; R37012, 10 km NW Barker Gorge, WA; R46863, R46892-93, R97962, Prince Regent River NR [NP], WA; R47282, 9 km W Beverley Springs, WA; R50777, Drysdale River NP, WA; R53333, R64869, 3 km SE Windjana Gorge, WA; R56355, 2 km E Mitchell River Falls, WA; R56437, confluence Barker River and Wombarella Creek, WA; R57117, Inglis Gap, WA; R58650, 10 km SE Lansdowne, WA; R70150, 28 km S Kununurra, WA; R70450, 11 km WSW Lissadell, WA; R70495, 43 km NW Fitzroy Crossing, WA; R70586, 11 km SSE Mt Percy, WA; R70662, 9 km SSE Mt Amy, WA; R75542, 16 km NE Bow River HS, WA; R77446, Camp Creek, Mitchell Plateau, WA; R80062, R80540, Hidden Is, WA; R80075-77, Gibbings Is, WA; R80087, R80095, Bathurst Is, WA; R80545, Irvine Is, WA; R81297, Koolan Is, WA; R87351-52, 27 km NW Bohemia Downs, WA; R87954, R87980-81, Caffarelli Is, WA; R95390, Thompson Spring, WA; R96973, 15 km SW Kings Cascade, WA; R97258, Wheelarra Hill, WA; R98039, 6 km W Evelyn Is, WA.

\section{Remarks}

Paratype R97258 is a specimen of Heteronotia spelea Kluge, 1963 from the Pilbara region, confirmed as $H$. spelea based on molecular data by Pepper et al. 2013). Liver sample of holotype and one paratype (R97258) stored frozen $\left(-75^{\circ} \mathrm{C}\right)$ at WAM.

\section{Peropus variegatus punctatus Fry, 1914}

Fry, D.B. (1914) On a collection of reptiles and batrachians from Western Australia. Records of the Western Australian Museum and Art Gallery 1: 174-210 [178]. 


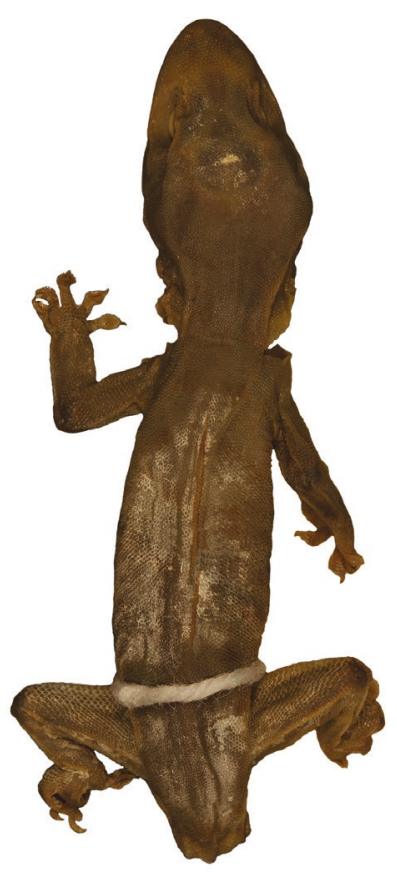

FIGURE 2 Peropus variegatus punctatus Fry, 1914 lectotype (R176100, formerly 9879). Scale bar $=10 \mathrm{~mm}$.

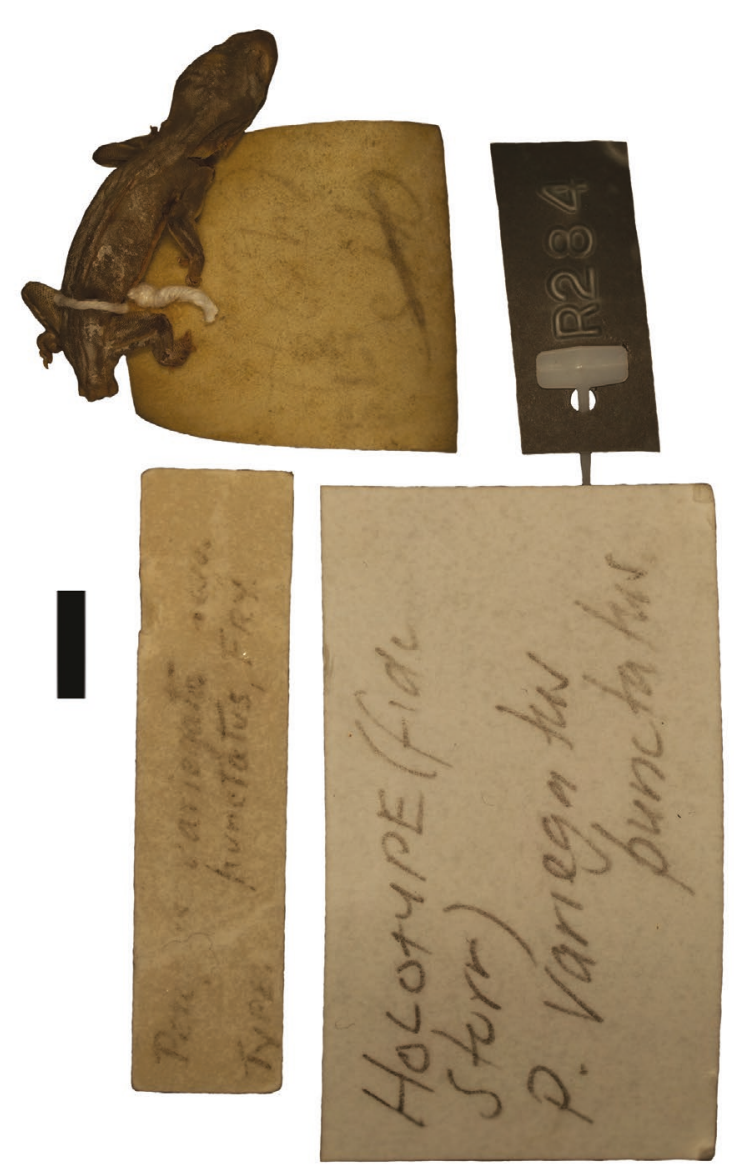

FIGURE 3 Tags and labels associated with the lectotype of Peropus variegatus punctatus Fry, 1914 (R176100, formerly 9879). Scale bar $=10 \mathrm{~mm}$.

\section{Lectotype}

R176100 (formerly 9879), 'Strelley River, Pilbara' WA [20 $\left.33^{\prime} \mathrm{S}, 119^{\circ} 00^{\prime} \mathrm{E}\right]$, J.B. Cleland, collection date unknown, presumably 1907, first accessioned into WAM collection as 9879 on 27 March 1909 (Figures 2-3), see Doughty et al. (2018a) for lectotype designation.

\section{Current status and nomenclature}

Gehyra punctata, see Bustard (1965a) for generic placement and Bustard (1965b) specific status.

\section{Remarks}

For the description of Peropus variegatus punctatus, Dene Barrett Fry used material made available to him at the AMS for identification by the then Director of WAM, Bernard Henry Woodward, as no staff at the time had herpetological interests. In addition to Peropus variegatus punctatus, Fry described several other reptile species based on specimens made available to him from the WAM collection for which locality details were lacking or provided only in broad terms (see also, Diplodactylus woodwardi and Ophioseps repens in this paper). In the description for $P$. variegatus punctatus, Fry did not list a type specimen, or any other specimens examined; however, referred to 'a single female example of this widely distributed species from Strelley River, Pilbara' and an illustration of the variety 'figured by Messrs Lucas and Frost' from Lucas and Frost (1896, p. 124, pl. IX, fig. 3) (Figure 4A-B). In accordance with Article 73.2 of the Code (ICZN 1999), both the single female specimen from Strelley River and the specimen illustrated by Lucas and Frost (1896) are considered syntypes.

Since Fry's description of $P$. variegatus punctatus there has been no reference to the syntype series, only a single specimen referred to as the holotype. In the WAM 1960-61 Annual Report compiled by Glen Storr (Anonymous 1961), P. variegatus punctatus was listed with 'No. 9879' (pre R-prefix registration number) identified as the holotype with no mention of the Lucas and Frost figure. Although the holotype of $D$. woodwardi was listed with an ' $\mathrm{R}$ ' registration number (R14370, formerly 9876, reregistered with $\mathrm{R}$ prefix in 1962), the specimen identified as the P. variegatus punctatus holotype was only listed as '9879', despite other specimens in the series 9871-77 being reregistered on 12 July 1962 according to notations by Storr in the original specimen catalogue. Although it was assumed there was only a single specimen, the 'single female example... from Strelley River', the fixation of a lectotype by inference of a holotype, in accordance with Article 74.6 of the Code (ICZN 1999), by Storr does not apply as Fry clearly refers to the illustration in Lucas and Frost (1896, p. 124, pl. IX, fig. 3) (Figure 4A). As Storr's (Anonymous 1961) treatment of 9879 as the holotype did not expressly clarify the specimen was selected from a series, in accordance with Article 74.5 of the Code (ICZN 1999), the use of the term holotype did not constitute a valid lectotype designation. 

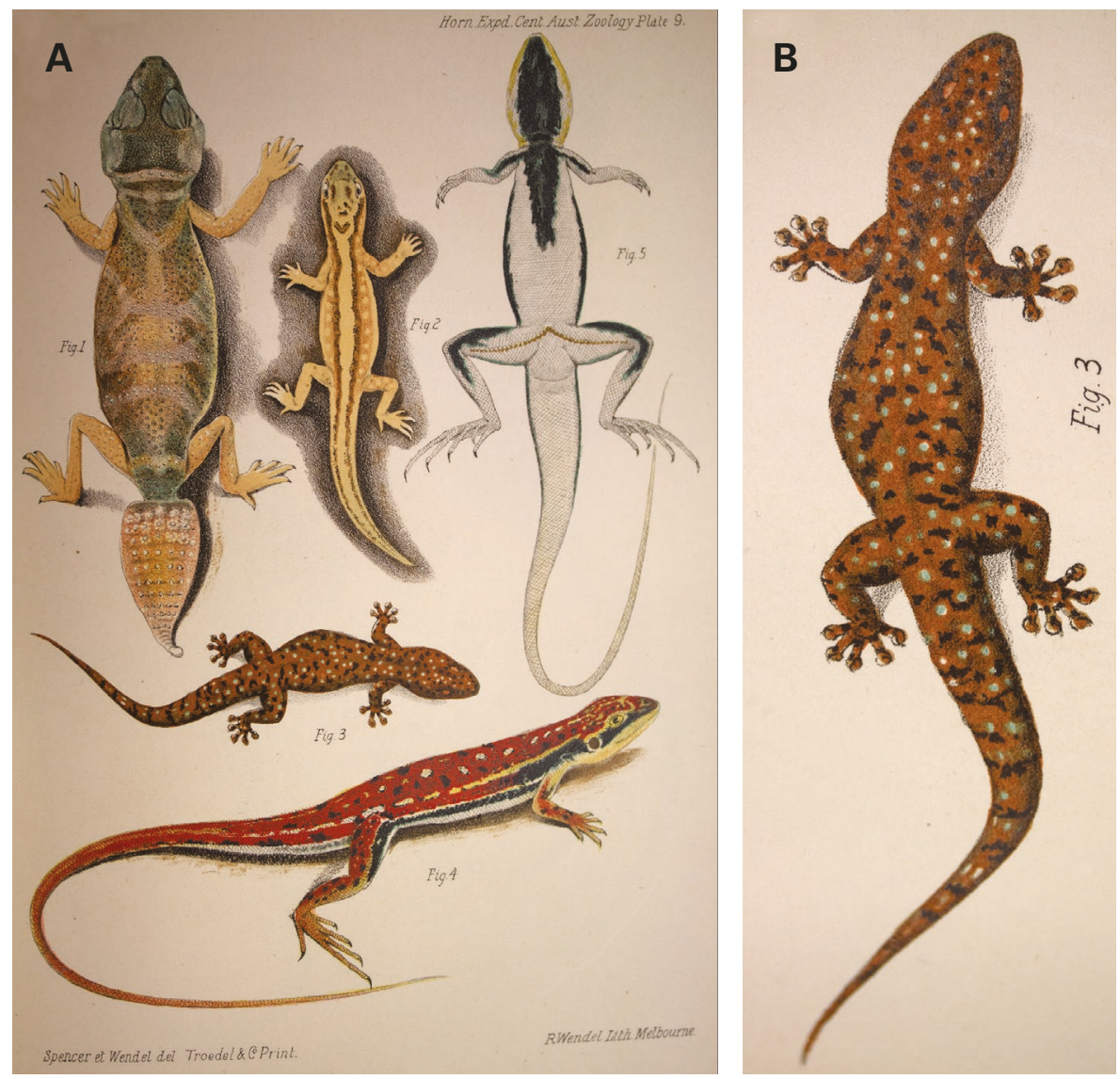

FIGURE $4 \quad$ A) Plate IX of Lucas and Frost (1896, p. 124); B) Showing Peropus variegatus punctatus Fry, 1914 paralectotype (Fig. 3) in detail.

Mitchell (1965) indicated that searches for type material in the AMS and WAM collections in the early 1960s failed to locate any type material of the species. Following Mitchell (1965), Cogger et al. (1983) subsequently listed the holotype as presumed lost. Although Fry (1914) referred to AMS specimens for other species in the paper, including some designated as type material of some new species (e.g. Egernia formosa and Lygosoma (Rhodona) picturatum), neither Cogger (1979) nor Shea and Sadlier (1999) could locate any evidence of $P$. variegatus punctatus type material in the AMS collection.

A single specimen maintained in the WAM type collection with a vellum tag tied to it with what appears to be the number ' 915 ', which is crossed out with ' 515 ' written below it, and '9879' in addition to some indecipherable text below (Figure 3). This specimen also has a dymo-printed label attached by a plastic tag fastener through the specimen's neck (now dislodged) with the number 'R284' (Figure 3); however, examination of old hardcopy registration catalogues indicates the registration R284 is associated with a specimen of Gehyra variegata, collected by W.B. Alexander from $100 \mathrm{~km}$ east of Kalgoorlie, WA, far from the occurrence of any G. punctata-like species. The specimen also has two loose labels accompanying it, a faded handwritten label and a more recent WAM specimen label (Figure 3). The faded handwritten label, presumably in Fry's hand, states 'Peropus variegatus var. punctatus, FRY' across two rows followed by 'TYPE' in the bottom left corner (Figure 3 ). The more recent label is a WAM specimen label with 'HOLOTYPE (fide Storr) P. variegatus punctatus' written on the back in Storr's hand (Figure 3). Despite the poor condition of the specimen, it has been identified as what is widely accepted as G. punctata based on elongate chin shields with shallow mental, seven subdigital lamellae on the fourth toe and visible dorsal pattern consistent with the commonly observed largebodied form of G. punctata in the Pilbara region.

Early registration tags, including those used during the period when the number R284 would have been used, were lead tags with registration numbers hand punched into them, indicating the dymo tag was more recently attached to the specimens, for unknown reasons. As the vellum tag predates the dymo-printed label and its attachment method, it appears the dymo tag R284 was erroneously attached to the specimen. No specimens of $G$. variegata with the registration number R284 or other numbers with matching collection data have been located and the specimen of $G$. variegata associated with the registration number R284 is presumed lost. 
Despite this erroneous registration tag attached to the specimen, there is no evidence the specimen bearing the old catalogue number '9879' was ever reregistered into the new catalogue and given a registration number with an $\mathrm{R}$ prefix. To ensure this specimen is incorporated into the current registration system and to pervert further use of the erroneous registration number, it has been reregistered as $\mathrm{R} 176100$.

The other syntype, illustrated in Lucas and Frost (1896, p. 124, pl. IX, fig. 3) (Figure 4A-B) is likely based on a specimen collected during the Horn Expedition and was possibly subsequently deposited in the NMV along with other specimens collected during the expedition. The NMV collection currently contains 19 Gehyra specimens collected during the Horn Expedition, with 'Professor W.B.[Walter Baldwin] Spencer' listed as the collector (NMV D242-45, D248-49, D252-54, D256, D259, D261-68), of which 16 are currently registered as G. variegata (D242-45, D248-49, D252-54, D256, D259, D262-65, D, D267) and three as G. punctata (D261, D266, D268). Based on observable patterning of these three faded specimens, the illustration in Lucas and Frost (1896) appears to be most similar to NMV D268; however, this cannot be confirmed with certainty as the specific configuration of pale and dark spots and blotches between the specimen and illustration differ considerably. This may be the result of the artist rendering a somewhat idealised version of the specimen, or it could represent another specimen, never accessioned and now missing. It is also possible that the illustration is a composite of multiple specimens and is not associated with a single specimen. If this were the case the WAM lectotype would actually be a holotype.

Despite Fry only referring to the single female specimen from Strelley River and the illustration in Lucas and Frost, it is apparent a series of Gehyra specimens were made available to him which provided comparative material for the description of $P$. variegatus punctatus. This included additional material also from Strelley River, most of which appear to have been considered to be the then wide-ranging $G$. variegata by Fry. Among the specimens provided to Fry from the WAM were two Gehyra variegata which were subsequently gifted to the AMS (numbered 524-55) and registered as AMS R4925-26. No correspondence detailing which specimens from the WAM collection were provided to Fry could be located; however, examination of early registration catalogues revealed a series of specimens which includes some known to have been loaned to Fry for identification, 9871-77 originally registered only as 'Newt' and 9878-81 registered as 'Lizard', which includes the types for $G$. variegatus punctatus and D. woodwardi. Additional notations in Glauert's hand state 'Gehyra variegata punctata (Fry)' next to 9871 and 'Note one of these is the type of frys Peropus variegatus punctatus Fry' below it. The only additional text by Glauert is 'Diplodactylus woodwardi, Fry TYPE' next to 9876. Notations in Storr's hand state 'reregistered as R 14371' in the row belonging to 9871 followed by R14372, R14373 and R14374 in the rows below corresponding with 9871 to 9874 , respectively. In the row for 9875 , Storr stated 'missing 12/7/69' with his signature below. The only other notation by Storr is in the row for 9876 where he states, 'reregistered as R 14370' and 'mounted' which corresponds with the type specimen of Diplodactylus woodwardi. No further notations are made in the remaining registrations 9878 to 9880 other than the original entry which only states 'Lizard' and 'Strelley River' as the collection locality for each of the entries. The entry associated with 9881 has a notation of 'Amphibolurus maculatus'.

In the later herpetology registration catalogue, R14371-74 were originally entered as 'Gehyra punctata' on 12 July 1962, however, punctata has subsequently been crossed out and replaced with 'pilbara' in an unknown hand. The 'pilbara' annotation occurred subsequent to the description of G. pilbara in 1965, though it is not known when. Notations in Storr's hand corresponding to these four registration numbers list their former registration numbers (9871-74) and the comment 're-registered on $12 / 7 / 1962$ ' in addition to 'labelled in Glauert's hand as "Cotypes". There is no further collection information provided; however, J.B. Cleland is identified as the collector of R14370 (formerly 9876), a specimen of Lucasium stenodactylum (Diplodactylus woodwardi holotype) identified by Storr. Notations in an early registration catalogue indicate the series of specimens (9871-74) were reregistered with an R prefix (R14371-74) as Gehyra punctata on 12 July 1962 by G.M. Storr; however, they were later identified as Gehyra pilbara. These four specimens all have faded vellum tags tied around their necks with faded handwriting in an unknown hand matching that of the holotype specimen (9879), presumably attached by Fry or Woodward to identify the specimens that were sent to Fry for identification. The tag attached to R14371 states '521' and '(9872)' below, R14372 states '520' and '(9871)', R14373 states '522' and '(9873)' and R14374 states '523' and '(9874)'; the three digit numbers were presumably assigned by Fry in the course of his working with the material. Reference to specimens in the AMS from the same collection verifies that these numbers are not field numbers as specimens from the same locality do not always have sequential numbers (Glenn Shea, personal communication, 2018). The latter four digit numbers correspond with former WAM registration numbers (9871-74). The four 'cotypes' identified by Glauert are not considered to be paratypes as Fry makes no mention of additional specimens other than the two considered syntypes above; however, it is likely these specimens were part of the series of specimens sent to Fry for identification and formed all or part of the comparative material for the description of $P$. variegatus punctatus.

Although $P$. variegatus punctatus was considered a wider ranging species at the time of description, the species range is now known to be confined to Western Australia and the two syntypes represent different species. Despite the poor condition of the specimen, the 
WAM lectotype designated by Doughty et al. (2018a) is representative of what is commonly referred to as $G$. punctata. The syntype illustration from Lucas and Frost (1896), relegated to paralectotype status by inference of lectotype designation, most closely resembles what has since been described as Gehyra moritzi Hutchinson, Sistrom, Donnellan and Hutchinson, 2014.

As for the Diplodactylus woodwardi holotype also collected by John Burton Cleland, no collection date for the lectotype of $G$. variegatus punctatus is listed in the WAM register or species description; however, he was reported to have been sent to Port Hedland in the Pilbara region from August to October 1907 in his role as a Pathologist with the Health Department to investigate trypanosome disease in imported camels (Anonymous 1907a, 1907b, 1908). Cleland also recorded and published notes on birds observed around Strelley River (Port Hedland-Marble Bar Road) during August-October 1907 where he also collected a Painted Firetail (Emblema picta) nest that was subsequently deposited at the WAM (Cleland 1909). As for the holotype of D. woodwardi, it is likely the G. variegatus punctatus lectotype was collected sometime during his time in the Pilbara in 1907.

\section{Phyllodactylus marmoratus alexanderi Storr, 1987}

Storr, G.M. (1987a) The genus Phyllodactylus (Lacertilia: Gekkonidae) in Western Australia. Records of the Western Australian Museum 13(2): 256-284 [281].

\section{Holotype}

R281, 'Eucla, WA (314' S, $\left.128^{\circ} 53^{\prime} \mathrm{E}\right)$ ', W.B. Alexander, in 1914.

\section{Paratypes (204)}

R24603-06, R31875, R54270, R66480, R66482-87, R66612, R66627-28, R66630-31, Eucla, WA; R2465051, Madura, WA; R24670-71, 42 km WSW Caiguna, WA; R25405-09, R25410-15, Koomooloobooka Cave, SA; R25472, Madura Cave, WA; R28707, Lynch Cave, WA; R29424-26, R29427*, R29428-29, 33 km N Madura, WA; R29443-54, R34494-500, 8 km S Loongana, WA; R29468-69, Madura Pass, WA; R31111-12, R54256, R54269, R67211*, R67212*, Israelite Bay, WA; R31872, 12 km SE Cook, SA; R31895, 42 W Caiguna, WA; R31897-99, 70 km ENE Balladonia HS, WA; R34449-50, 25 km ESE Cocklebiddy, WA; R36163, 52 km N Nullarbor HS, SA; R36168, 40 km N Madura, WA; R36472, 12 km NW Mundrabilla HS, WA; R37047, Wilson Bluff, WA; R37664, Nurina, WA; R37665 [in error, R37675*], 65 km SSE Reid, WA; R37672-73, 23 km S Reid, WA; R44979, Twilight Cove, WA; R45344-46, R45645, R66801-33, Toolinna Rockhole, WA; R45354, Mullendunya Tank, WA; R51807, Baxter Memorial, 35 km S Caiguna, WA; R53356-61, Balladonia HS,
WA; R54266, $91 \mathrm{~km} \mathrm{~W} \mathrm{Mundrabilla,} \mathrm{WA;} \mathrm{R54314,}$ 14 km W Caiguna, WA; R54315, Cocklebiddy, WA; R54329, 11 km E Cocklebiddy, WA; R66687-714, R66780-81, 3 km SW Toolinna Rockhole, WA; R66777, 11 km SW Toolinna Rockhole, WA; R66783, $14 \mathrm{~km}$ SSE Cocklebiddy, WA; R66862-71, 4 km S Eucla, WA; R66968-69, 10 km SSE Cocklebiddy, WA; R66987, 7 km NE Toolinna Rockhole, WA; R67240, Cocklebiddy, WA; R67314, Eyre, WA; R83963-64, Toolina Rockhole, WA; R91314-15, R91340, R91342, R91344, 15 km NNW Middini Beach, WA; R91316, $10 \mathrm{~km}$ NNW Middini Beach, WA; R91317, $10 \mathrm{~km}$ SSW Graham Tank, WA; R91318, R91339, R91341, R91343, R91348, 11 km E Kilidwerinia Granite Rock, WA; R91345, 6 km ENE Moondadong Rockhole, WA; R91346, 8 km SW Yuwanyadi Rockhole, WA; R91347, 19 km S Yuwanyadi Rockhole, WA; R9195657, 4 km SW Graham Tank, WA; R93736, 6 km E Toolinna Rockhole, WA; R93737, R93739-40, 7 km N Toolinna Rockhole, WA; R93738, 27 km N Toolinna Rockhole, WA.

\section{Current status and nomenclature}

Christinus alexanderi, see Wells and Wellington (1984) for generic placement and Donnellan et al. (2000) for species status.

\section{Remarks}

An additional 33 paratypes are held in the SAMA collection (R4983 A-B, R5831, R15789, R15980, R15981 A-B, R23042-48, R25620, R25632, R2563536, R25657, R25665, R25669-70, R26264, R26402, R29218-24, R117513 A-B). Storr stated there were 240 paratypes, all listed under 'Material'; however, only 237 specimens are listed there. Paratype R66612 was listed by Storr twice. Additional specimens were available to Storr at the time of description; however, there is no evidence which, if any, of the specimens were examined. One paratype registration number presented by Storr is in error; R37665 is associated with a specimen of Heteronotia binoei from $65 \mathrm{~km}$ SSE Reid, WA. The correct registration is R37675 which has subsequently been identified as a specimen of Christinus marmoratus. Of the 204 paratypes listed by Storr, 69 have since been identified as specimens of Christinus marmoratus: R29443-54, R29468, R31111-12, R34449-50, R37665, R44979, R45344-46, R45645, R54256, R54266, R54269, R54314, R66480, R66482-87, R66612, R66628, R66687-88, R66701, R66703, R66706, R67211-12, R66777, R66783, R66801, R66987, R67211-12, R67314, R91314-18, R91339-40, R91342-45, R91348, R91956-57, R93736-40.

Four paratypes (R29427, R37675, R67211-12) could not be located and are considered lost. R29427 was not recorded in a 2008 audit or subsequent searches, R37675 was last recorded in a 2008 audit but its presence has not been confirmed since and the presence of R67211-22 has not been confirmed since a 2000 audit and have not been located since. 


\section{Family Pygopodidae}

\section{Aclys concinna Kluge, 1974}

Kluge, A.G. (1974) A taxonomic revision of the lizard family Pygopodidae. Miscellaneous Publications of the Museum of Zoology, University of Michigan 147: 1-221 [46].

\section{Holotype}

R17312, 'Sorrento (a suburb of Perth), 11 mi [17.7 km] NW Perth, WA' [31 $49^{\prime}$ 'S, $115^{\circ} 45^{\prime}$ E], A.E. Boyd, 6 December 1962.

\section{Paratype}

R41156, 13 km N Jurien Bay, WA.

\section{Current nomenclature}

Delma concinna concinna, see Kluge (1976) and Jennings et al. (2003) for synonymy of Aclys and Storr (1987) for subspecific status.

\section{Aclys concinna major Storr, 1987}

Storr, G.M. (1987b) Three new legless lizards (Pygopodidae) from Western Australia. Records of the Western Australian Museum 13: 345-355 [354].

\section{Holotype}

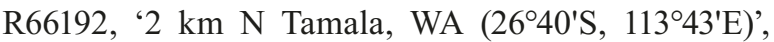
T.M.S. Hanlon and G. Harold, 29 August 1979.

\section{Paratypes (2)}

R96898, R97010, 7 km NE Tamala, WA.

\section{Current nomenclature}

Delma concinna major, see Jennings et al. (2003).

\section{Remarks}

Liver sample of one paratype (R96898) stored frozen $\left(-75^{\circ} \mathrm{C}\right)$ at WAM.

\section{Aprasia clairae Maryan, How \& Adams, 2013}

Maryan, B., How, R.A. and Adams, M. (2013b) A new species of the Aprasia repens species-group (Squamata: Pygopodidae) from Western Australia. Records of the Western Australian Museum 28: 30-43 [37].

\section{Holotype}

R156901, 'Turtle Bay, East Wallabi Island, Houtman Abrolhos Islands, WA $\left(28^{\circ} 25^{\prime} 55^{\prime \prime} \mathrm{S}, 113^{\circ} 44^{\prime} 08^{\prime \prime} \mathrm{E}\right)$ ', B. Maryan and R.A. How, 8 November 2005.

\section{Paratypes (2)}

R127527, 20 km SSE Dongara, WA; R156892, Turtle Bay, East Wallabi Is, Houtman Abrolhos, WA.

\section{Remarks}

Liver sample of holotype and one paratype (R156892) stored at EBU and liver sample of one paratype (R127527) stored at WAM.

\section{Aprasia haroldi Storr, 1978}

Storr, G.M. (1978b) Taxonomic notes on the reptiles of the Shark Bay region, Western Australia. Records of the Western Australian Museum 6: 303-318 [307].

\section{Holotype}

R54766. 'Parrot Isle, $5 \mathrm{~km} \mathrm{~N}$ of Carrarang [HS], WA $\left(26^{\circ} 20^{\prime} \mathrm{S}, 113^{\circ} 30^{\prime} \mathrm{E}\right)^{\prime}, \mathrm{G}$. Harold and M. Peterson, 27 August 1976.

\section{Paratypes (7)}

R54765, Parrot Isle, Carrarang Stn, WA; R54847, R54891-95, False Entrance Well, Carrarang Stn, WA.

\section{Aprasia inaurita Kluge, 1974}

Kluge, A.G. (1974) A taxonomic revision of the lizard family Pygopodidae. Miscellaneous Publications of the Museum of Zoology, University of Michigan 147: $1-221$ [51].

\section{Paratype}

R5280. Eyre, WA.

\section{Remarks}

Holotype in the NMV collection, registration number D11181, collected from 'Birthday Tank, Sunset Country (N Cowangie), Victoria' by A.J. Coventry, 2 November 1965. An additional 22 paratypes are held in other collections: 13 at SAMA (SAMA R379, R1673, R2752, R2808, R3089a, R3885, R4302, R8410, R8994, R9210, R9215, R11655, R12617), seven at NMV (NMV D594, D4686，D4751，D7171，D11181，D11985, D18001), one at AMS (AMS R14382) and one at UMMZ (UMMZ 131672).

\section{Aprasia litorea Maryan, Bush \& Adams, 2013}

Maryan, B., Bush, B. and Adams, M. (2013a) Morphological and molecular assessment of Aprasia fusca and A. rostrata (Squamata: Pygopodidae), with a description of a new species from Lake MacLeod region, Western Australia. Records of the Western Australian Museum 28: 144-163 [155].

\section{Holotype}

R141605, '1 km S of Gnaraloo Homestead, WA $\left(23^{\circ} 49^{\prime} 29 " \mathrm{~S}, 113^{\circ} 31^{\prime} 32^{\prime \prime E}\right)^{\prime}, \mathrm{B}$. Maryan and B. Bush, 20 June 2000. 


\section{Paratypes (7)}

R116614, 9 km NE Cape Cuvier, WA; R116656, 0.5 km S Gnaraloo HS, WA; R116660, 7km SSW Gnaraloo HS, WA; R141606, Cape Cuvier, WA; R151305-07, 18 km SSE Quobba HS, WA.

\section{Remarks}

Liver sample of holotype and five paratypes (R116656, R116660, R141606, R151305-06) stored frozen $\left(-75^{\circ} \mathrm{C}\right)$ at WAM.

\section{Aprasia parapulchella Kluge, 1974}

Kluge, A.G. (1974) A taxonomic revision of the lizard family Pygopodidae. Miscellaneous Publications of the Museum of Zoology, University of Michigan 147: $1-221$ [53].

\section{Holotype}

R41231, 'Coppins Crossing, Molonglo R, ACT' [35 $\left.20^{\prime} \mathrm{S}, 149^{\circ} 05^{\prime} \mathrm{E}\right]$, R. Barwick, R. Jennings and A. Kluge, 20 December 1971.

\section{Remarks}

An additional 21 paratypes held in other collections: 12 at UMMZ (UMMZ 131157, 131193-94, 131196-204), four at AMS (AMS R31632-35), two at NMV (NMV D15389, D18045), one at QM (QM J22308) and one at FMNH (FMNH 195547). The holotype retains University of Michigan field tags stating, 'Field Series AGK' and the field number '1317'. A label with the holotype lists the collectors and states the location as '5.25 miles WNW of Canberra A.C.T. (Coppins Crossing)'.

\section{Aprasia picturata Smith \& Henry, 1999}

Smith, L.A. and Henry, J. (1999) Aprasia picturata (Squamata: Pygopodidae), a new legless lizard from the interior of Western Australia. Journal of the Royal Society of Western Australia 82: 75-77 [75].

\section{Holotype}

R126998, '35 km E of Leonora, WA (2857'15"S, 12147'23"E)', J. Henry, 3 October 1996.

\section{Paratype}

R131647, 3.5 km S Minaea HS, WA.

\section{Remarks}

Liver sample of holotype and heart sample of paratype stored frozen $\left(-75^{\circ} \mathrm{C}\right)$ at WAM.

\section{Aprasia repens rostrata Parker, 1956}

Parker, H.W. (1956) The lizard genus Aprasia; Its taxonomy and temperature-correlated variation. Bulletin of the British Museum (Natural History) 3: 365-385 [384].

\section{Holotype}

R13861, 'Hermite Island, Monte Bello Group [Montebello Islands], WA' [20²9'S, $115^{\circ} 31^{\prime}$ E], F.L. Hill, 17 August 1952 (Figure 5).

\section{Current status}

Aprasia rostrata, see Kluge (1974).

\section{Remarks}

For the type specimens Parker (1956) only stated 'Holotype a male, collected 17.viii.52 on Hermite Island and allotype female collected on the same island 22.v.52'; he did not provide a registration number or a collection depository for either specimen. The specimen R13861 was identified as the holotype in the list of type specimens presented in the WAM 19591960 Annual Report (Anonymous 1960), a registration number subsequently also reported by Kluge (1974) and Cogger et al. (1983). Kluge (1974) confirmed the identity of the holotype based on diagnostic morphology consistent with that presented by Parker (1956). The identity of the allotype (= Paratype) nominated by Parker was not determined; however, Parker (1956) referrs to the Aprasia sp. specimen identified by Hill (1955) from the type locality as being deposited at the NHMUK. Only one Aprasia from Hermite Is is held in the NHMUK collection and is maintained as a paratype, NHMUK 1955.1.4.48. A typewritten note with three lines of text is retained with the holotype specimen (Figure 5). The note has minor damage resulting in the loss of some text; however, visible text states 'Aprasia repens rostrata Parker 1956,' on the first line, '(Nat. Hist.) Zool. 3: 384, Specime...' on the second, followed by 'number, HOLOTYPE.' on the third line (Figure 5).

\section{Aprasia rostrata fusca Storr, 1979}

Storr, G.M. (1979b) Five new lizards from Western Australia. Records of the Western Australian Museum 8: 134-142 [136].

\section{Holotype}

R61077, ' $3 \mathrm{~km} \mathrm{NW}$ of Bullara, WA $\left(22^{\circ} 40^{\prime} \mathrm{S}\right.$, $114^{\circ} 02^{\prime}$ E)', T.M.S. Hanlon and D. Knowles, 14 December 1978.

\section{Paratypes (3)}

R61454, mouth of Yardie Creek, WA; R61078, R61079, 3 km NW Bullara, WA.

\section{Current status}

Junior synonym of Aprasia rostrata, see Maryan et al. (2013a).

\section{Remarks}

The subspecies was raised to full species by Storr et al. (1990) without comment and synonymised with $A$. rostrata following morphological and allozyme analysis by Maryan et al. (2013a). 


\section{Aprasia smithi Storr, 1970}

Storr, G.M. (1970) Aprasia smithi a new worm-lizard (Pygopodidae) from Western Australia. Western Australian Naturalist 11: 141 [141].

\section{Holotype}

R34325, 'Kalbarri, WA (2743'S, $\left.114^{\circ} 10^{\prime} \mathrm{E}\right)$ ', W.J. Marsh, 13 July 1969.

\section{Aprasia striolata glauerti Parker, 1956}

Parker, H.W. (1956) The lizard genus Aprasia; Its taxonomy and temperature-correlated variation. Bulletin of the British Museum (Natural History) 3: 365-385 [378].

\section{Holotype}

R10949, 'Albany, WA', [3502'S, 117 53'E], collected by F.R. Bradshaw, accessioned November 1953 [collection date unknown].

\section{Paratypes (9)}

R6782 (six specimens, one now R94880 and three now NHMUK (NHMUK 1955.1.4.21-23), one unknown), R10950-51, R94880 (formerly R6782 part), Albany, WA; R7214 Narrikup, WA.

\section{Current status}

Junior synonym of Aprasia striolata, see Kluge (1974)

\section{Remarks}

According to Parker (1956), the registration number R6782 was associated with six specimens, all from the type locality; however, only a single specimen could be located bearing this registration number. One specimen was subsequently reregistered as R94880 and three were gifted to the NHMUK by, then Curator and Director of the WAM, Ludwig Glauert in 1955 and registered as NHMUK 1955.1.4.21-23. The location of the remaining paratype associated with R6782 is unknown and it is considered lost; however, it is possible this specimen was gifted or exchanged with another museum.

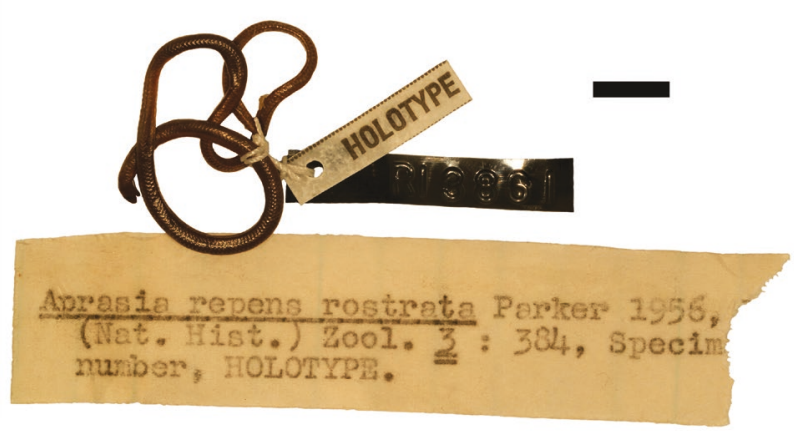

FIGURE 5 Aprasia repens rostrata Parker, 1956 holotype (R13861) and associated loose label retained with specimen. Scale bar $=10 \mathrm{~mm}$.
Examination of early registration catalogues showed R6782 was part of a series of six specimens, originally registered as Aprasia pulchella, which were registered as a group as R6782-87, and not as six specimens under R6782 as stated by Parker in the description. It appears the six specimens were all tagged with R6782 on the original hand punched lead tags due to the unclear registration entry as no other evidence of specimens matching the registration numbers R6783-87 could be located. Despite the original lead registration tag having been removed from R94480, remarks in the current digital herpetology specimen database, presumably from when the specimen was reregistered, state 'old number R6782', indicating the specimens were all erronrously tagged with R6782.

Parker (1956) listed five additional paratypes held in other collections; four in AMS (AMS R12305 (three specimens), AMS R3468) and one at NHMUK (NHMUK 1911.12.18.3). One of the AMS registration numbers (R12305) is associated with three specimens, two of which have subsequently been reregistered as R27521 and R27522 (Shea and Sadlier 1999).

\section{Aprasia wicherina Maryan, Adams \& Aplin, 2015}

Maryan, B., Adams, M. and Aplin, K.P. (2015a) Taxonomic resolution of the Aprasia repens speciesgroup (Squamata: Pygopodidae) from the Geraldton Sandplains: a description of a new species and additional mainland records of $A$. clairae. Records of the Western Australian Museum 30(1): 12-32 [22].

\section{Holotype}

R173106, 'Wicherina Water Reserve, WA (2843'02"S, 115 01'11"E)', R. Lloyd and B. Maryan, 1 August 2013.

\section{Paratypes (3)}

R121129, R121132, R146587, Wicherina Water Reserve, WA.

\section{Cryptodelma nigriceps Fischer, 1882}

Fischer, J.G. (1882) Herpetologische Bemerkungen. II. Neue Eidechsen aus Australien und Polynesien. Archiv für Naturgeschichte 48: 286-302 + pl. XVI [290].

\section{Neotype}

R102063, 'Yule River, WA (2040'S, 118²1'E)', D. Robinson, [9 February] 1990.

\section{Current nomenclature}

Pygopus nigriceps, see Kinghorn (1926).

\section{Remarks}

Neotype designated by James et al. (2001). The original holotype designated by Fischer (1882), SMNS 2259 from 'Nicolbay, Westaustralien' [Nickol Bay, WA] by F. von Müller (collection date unknown) was believed to have been destroyed during World War II 
and is considered lost (Schlüter and Hallermann 1997). Kinghorn (1926) incorrectly lists the type locality of Pygopus schraderi, stating 'Holotype from Milparinka, western New South Wales' (p.46), which at the time was considered a junior syonym of $P$. nigriceps. Heart and blood sample of neotype stored frozen $\left(-75^{\circ} \mathrm{C}\right)$ at WAM.

\section{Delma australis Kluge, 1974}

Kluge, A.G. (1974) A taxonomic revision of the lizard family Pygopodidae. Miscellaneous Publications of the Museum of Zoology, University of Michigan 147: $1-221[77]$.

\section{Holotype}

R27359, 'Port Lincoln, SA' [3444'S, 13552'E], G.M. Storr, 19 October 1966.

\section{Paratype}

R24528, Eyre Peninsula, SA.

\section{Remarks}

An additional 18 paratypes held in other collections: 14 at SAMA (SAMA R380, R3852, R4301, R5375, R9189，R9213，R9224，R10374，R10376，R12454-55, R12481, R12669, R12751) and four at NMV (NMV D8857-58, D15440, D15456).

\section{Delma borea Kluge, 1974}

Kluge, A.G. (1974) A taxonomic revision of the lizard family Pygopodidae. Miscellaneous Publications of the Museum of Zoology, University of Michigan 147: $1-221$ [81].

\section{Holotype}

R37131, '48 miles [78 km] south of Darwin, NT' [1254'S, 131 $\left.{ }^{\circ} 08^{\prime} E\right]$, P.J. Fuller, 25 June 1970.

\section{Paratypes (33)}

R11240, R11449, Wotjulum, WA; R13466, Troughton Is, WA; R13496, R34331-32, Yirrkala, NT; R13570, R27614-15, Kalumburu, WA; R14072, R34333, Cockatoo Is, WA; R19814, King Leopold Ranges, WA; R21980, R40296, R40835, Darwin, NT; R23048, 25 km E Bohemia Downs, WA; R23480, Nightcliff, NT; R24001, 11 km N Adelaide River, NT; R24198, Helen Springs, NT; R25092, 61 km SSE Wyndham, WA; R25201, 32 km E Jiggalong, WA; R26224, Parap, Darwin, NT; R26806, Gogo, WA; R27613, Mt Anderson, WA; R28656, Barrow Is, WA; R29143, R34343, Koolan Is, WA; R32142-43, St George Ranges, WA; R37045, White Mountain Hills, WA; R37371, Rosemary Is, WA; R37406, Hermite Is, WA; R37703, Hidden Valley, WA.

\section{Remarks}

Kluge (1974) did not individually designate paratype specimens, only stating that paratypes were 'All other specimens listed under borea in the Specimens
Examined section (Appendix II) whose place of collection is north of $20^{\circ} \mathrm{S}$ Lat' which excludes four specimens from the list only slightly south of $20^{\circ} \mathrm{S}$ Lat, ranging from $20^{\circ} 22^{\prime}$ to $20^{\circ} 50^{\prime}$ (R25201, $20 \mathrm{mi}$ [32 km] E Jiggalong, WA; R28656, Barrow Is, WA; R37371, Rosemary Is, WA; R37406, Hermite Is, WA). An additional 51 paratypes are held in other collections: 22 at AMS (AMS R3662a-b [now R3662 and R62673], R4162，R8249，R12794，R12841，R12877，R12901, R13004, R13471, R13569a-b [now R13569 and R62670], R13570a-b [now R13570 and R62671], R13609, R13648 [x2 specimens, now R13648 and R32672], R13713, R13777, R19121, R30014-15; Shea and Sadlier 1999), seven at NMV (NMV D5528, D8492-94, D8763, D10086, D14205,), five at USNM (USNM 128260, 128679-82), five at NTM (NTM 9 [now R32300], 1680 [now R32293], 3080 [now R32295], 4582 [now R32296], 4950 [now R32298]; Horner 1999), four at MCZ (MCZ R48812-15), three at AMNH (AMNH 102388-89, 86288), three at QM (QM J2261-62, J21775), one at SAMA (SAMA R8409) and one at UMMZ (UMMZ 131239).

\section{Delma butleri Storr, 1987}

Storr, G.M. (1987b) Three new legless lizards (Pygopodidae) from Western Australia. Records of the Western Australian Museum 13: 345-355 [346].

\section{Holotype}

R76742, '5 km SE Gnaraloo, WA (2352'S, 11332'E)', G. Harold and C. Winton, 22 May 1982.

\section{Paratypes (95)}

R18531 [in error, R18551], Queen Victoria Spring, WA; R21073, $33 \mathrm{~km}$ W Carnegie, WA; R28359, $16 \mathrm{~km}$ N Ethel Creek HS, WA; R36649, $43 \mathrm{~km} \mathrm{NE}$ Maralinga, WA; R44362, 56 km NW Mt Lindsay, WA; R45850, R57087-88, R57093-94, Dirk Hartog Is, WA; R47709, Northampton, WA; R48184-88, R48261, R48270, R75559, East Yuna NR, WA; R53255-56, Ivor Rocks, WA; R53277, 75 km N Kalgoorlie, WA; R53291, 27 km NE White Cliffs, WA; R53459-60, Newman Rock, WA; R54556, 25 km SSE Denham, WA; R57522, 40 km NE Yuna, WA; R57541, 44 km NE Yuna, WA; R57959, R58072, 4 km E Boingaring Rocks, WA; R59854-55, 17 km N Charlina Rock, WA; R62822, $22 \mathrm{~km}$ SE Mt Keith, WA; R64727, 9 km SW Mt Lockeridge, WA; R64754-55, R78680, R78688-89, nr. Mt Manning Range, WA; R64794, R64813-14, Blue Hill, WA; R65463, R65484, 30 km NW Heartbreak Ridge, WA; R65531, R65539, R65569-70，R65590，R65654，R72503，R72537, R74557, R74591, R74597, nr. Buningonia Spring, WA; R67188, 15 km NE Bungalbin Hill, WA; R67974, 35 km SSE Dandaraga, WA; R69080, R69104, R69108, R74658, 8-9 km ENE Yuinmery, WA; R69288, 12 km SSE Banjawarn, WA; R70876-77, Mt Windarra, 
WA; R70893, Yowie Rockhole, WA; R71775, $32 \mathrm{~km} \mathrm{~S}$ Woolgangie, WA; R72248, R72255-56, R72285-86, R72291, nr. Boorabbin, WA; R72669, R72728, 3 km NE Comet Vale, WA; R73212, R73228-29, 6 km ENE, Yowie Rockhole, WA; R74677, R74679, 24 km ENE Yuinmery, WA; R74784, 9 km SSE Banjawarn, WA; R76121, 16 km SSW Mt Jackson, WA; R76645, 3 km SE Gnaraloo, WA; R78548, $30 \mathrm{~km}$ SE Mt Keith, WA; R78553, 29 km SE Mt Keith, WA; R85305, 15 km E White Cliffs, WA; R85600-01, R85603-04, 39 km ENE Laverton, WA; R85605-06, 7 km WNW Point Salvation, WA; R86658, $17 \mathrm{~km}$ NE Youanmi, WA; R91510, 4 km E Zanthus, WA; R94077, 53 km NNE Queen Victoria Spring, WA; R94585, Marandoo, WA.

\section{Remarks}

For paratypes Storr (1987b) stated 'The 97 specimens listed under Material examined'; however, only 95 specimens are listed there. One registration number listed by Storr is believed to be in error, the specimen associated with the registration R18531 is a Lerista timida from Newman Rock, WA. The only other specimen that matches the locality presented by Storr and was available to him at the time of description is R18551.

\section{Delma desmosa Maryan, Aplin \& Adams, 2007}

Maryan, B., Aplin, K.P. and Adams, M. (2007) Two new species of the Delma tincta group (Squamata: Pygopodidae) from northwestern Australia. Records of the Western Australian Museum 23: 273-305 [288].

\section{Holotype}

R102657, 'Site Cooma 4, Little Sandy Desert, WA (2406'17"S, 120¹9'30"E)', S. van Leeuwen, 10 October 1996.

\section{Paratypes (31)}

R45809-10, Wallal Downs HS, WA; R63313, Djaluwon Creek, WA; R64001, Anketell Ridge, WA; R64097, Staffords Bore, WA; R64143, Breaden Pool, WA; R64186, 1 km S Wadawalla Well, WA; R75798, Dragon Tree Soak, WA; R75830, Anna Plains HS, WA; R87007, R114555, Sandfire Roadhouse, WA; R87353, 3 km SE Wallal Downs HS, WA; R88535-41, 55 km S Anna Plains HS, WA; R94757, R94776-77, 80 km S Telfer Mine, WA; R102650, [Site] Cooma 5 Little Sandy Desert, WA; R108477, 18 km S Lake Hancock, WA; R126496, R126498, Gibson Desert NR, WA; R132802, Warri Airstrip, WA; R139089, Mandora Stn, WA; R140442, Yanneri Lake, WA; R145073, Officer Basin area, WA; R151252, Townsend Ridges, WA.

\section{Remarks}

A total of 46 paratypes were designated by Maryan et al. (2007) of which 31 are held in the WAM collection. An additional 17 paratypes are held in other collections:
13 at NTM (NTM R14901, R15038, R15138, R15144, R15146, R15151, R15230, R15501, R17987, R20250, R26789, R32301, R34489), two at AMS (AMS R100853, R101548) and two at SAMA (SAMA R48671, R59561). Liver of holotype and four paratypes (R102650, R132082, R139089, R145073) stored at EBU. Liver of two paratypes (R114555, R151252) stored frozen $\left(-75^{\circ} \mathrm{C}\right)$ at WAM.

\section{Delma elegans Kluge, 1974}

Kluge, A.G. (1974) A taxonomic revision of the lizard family Pygopodidae. Miscellaneous Publications of the Museum of Zoology, University of Michigan 147: $1-221$ [82].

\section{Holotype}

R20070, 'Mount Herbert, northern foothills of Hamersley Range, WA', [2119'32"S, 117²1'59"E], Western Australia-South Australia Museum Hamersley Expedition, 4 August 1958.

\section{Paratype}

R31051, Mt Tom Price Townsite, WA.

\section{Remarks}

A second paratype specimen is held in the SAMA collection (SAMA R4475, Tambrey, WA).

\section{Delma fraseri petersoni Shea, 1991}

Shea, G.M. (1991) Revisionary notes on the genus Delma (Squamata: Pygopodidae) in South Australia and the Northern Territory. Records of the South Australian Museum 25: 71-90 [80].

\section{Paratypes (3)}

R100636, 20 km NNE Queen Victoria Springs, WA; R100930, 25 km NNE Queen Victoria Spring, WA; R100964, Jumpbuck Rd, Plumridge Lakes, WA.

\section{Current status}

Delma petersoni, see Jennings et al. (2003).

\section{Remarks}

Holotype specimen held in the SAMA collection, $\mathrm{R} 20804$, ' $\mathrm{N}$ end stock route, SA (32 $\left.51^{\circ} \mathrm{S}, 135^{\circ} 57^{\prime} \mathrm{E}\right)$ ', collected by the Nature Conservation Society, 13 October 1981. Eleven paratypes were designated by Shea (1991) of which three are held in the WAM collection, the remaining eight paratypes are held in the SAMA collection (R3853, R10586, R14985, R20790, R20816, R32259, R32463, R33681). Jennings et al. (2003) elevated the subspecies to specific status following phylogenetic analysis of mitochondrial and nuclear DNA which indicated $D$. fraseri was not monophyletic. 


\section{Delma haroldi Storr, 1987}

Storr, G.M. (1987b) Three new legless lizards (Pygopodidae) from Western Australia. Records of the Western Australian Museum 13: 345-355 [350].

\section{Holotype}

R85094, '11 km NNW Uaroo [HS], WA (2241'S, $\left.115^{\circ} 20^{\prime} \mathrm{E}\right)^{\prime}, \mathrm{G}$. Harold and C. Winton, 11 August 1983.

\section{Paratypes (9)}

R45243, 45 km N Windy Corner, WA; R45811, Wallal, WA; R46043, 146 km E McLarty Hills, WA; R51722, 2 km SW Barradale, WA; R63427, Twin Heads, WA; R63632, 14 km SW The Governer, WA; R64703, Balgo Mission, WA; R64715, Marandoo, WA; R73630, Ophthalmia Range, WA.

\section{Current status}

Junior synonym of Delma butleri, see Shea (1991) and remarks below.

\section{Remarks}

Shea (1991) considered $D$. haroldi a junior synonym of D. butleri. While the species continued to be recognised as distinct by most subsequent authors (e.g. Cogger 2000, 2014; Wilson and Swan 2003, 2017; Maryan et al. 2007; Brennan et al. 2016), we accept the evidence of molecular data presented by Brennan et al. (2016) and additional unpublished data (Ian Brennan, personal communication, 2016) to follow the earlier synonymy of Shea (1991). One paratype specimen, R46043 is an alizarin-alcian stained skeleton specimen stored in a glycol solution; all other paratypes are whole specimens in $70 \%$ ethanol solution.

\section{Delma hebesa Maryan, Brennan, Adams \& Aplin, 2015}

Maryan, B., Brennan, I.G., Adams, M. and Aplin, K. (2015b) Molecular and morphological assessment of Delma australis Kluge (Squamata: Pygopodidae), with a description of a new species from the biodiversity 'hotspot' of southwestern Western Australia. Zootaxa 3946: 301-330 [321].

\section{Holotype}

R144237, 'Bandalup Hill, Ravensthorpe Range, WA (3340'29"S, 120²3'54"E)', R. Teale and G. Harold, 14 October 2000.

\section{Paratypes (6)}

R129674, 38 km W Kundip, WA; R131902, Hellfire Bay, Cape Le Grand NP, WA; R132154, Duke of Orleans Bay, Wharton Beach, WA; R144238, Bandalup Hill, Ravensthorpe Range, WA; R154234, Kundip, WA; R156978, Canal Rocks, WA.

\section{Remarks}

Liver sample of holotype and all paratypes, and heart of two paratypes (R129674, R131902) stored frozen $\left(-75^{\circ} \mathrm{C}\right)$ at WAM.

\section{Delma nasuta Kluge 1974}

Kluge, A.G. (1974) A taxonomic revision of the lizard family Pygopodidae. Miscellaneous Publications of the Museum of Zoology, University of Michigan 147: $1-221$ [109].

\section{Holotype}

R40178, 'Pollock Hills, 144 miles [231.7 km] west of Sandy Blight Junction, WA' [22 $\left.50^{\circ} \mathrm{S}, 127^{\circ} 35^{\prime} \mathrm{E}\right]$, J. Dell and G. Chapman, 25 May 1971.

\section{Paratypes (24)}

R13195a, R175033 (formerly part of R13195), Yardie Creek, WA; R14782, R27610, Woodstock Stn, WA; R14800*, Marble Bar, WA; R14806-07, Dales Gorge, WA; R20110, Millstream, WA; R20111, Asbestos Creek, WA; R20112, Mount Ulric Gorge, WA; R21773, 40 km NE Ningaloo, WA; R22806, Nichol Spring, WA; R25230, $18 \mathrm{~m}$ [28 km] NW Mount Vernon Stn [HS], WA; R25261, 21 km NW Ullawarra, WA; R25590, 3 km W Christmas Creek, WA; R26547, Mount Newman, WA; R27611-12, R28453, R28655, Barrow Is, WA; R28359, 16 km N Ethel Creek, WA; R31484, Southern Chichester Range, WA; R37018, Noreena Downs, WA; R37405, Hermite Is, WA.

\section{Remarks}

Kluge (1974) did not designate individually list paratype specimens, only stating 'All other species listed under nasuta in the Specimens Examined section (Appendix II) whose place of collection is between $20^{\circ}$ and $25^{\circ} \mathrm{S}$ Lat and west of $121^{\circ}$ E Long'. Of the 23 WAM specimens fulfilling these criteria listed by Kluge (1974), one has since been identified and designated as a paratype for Delma butleri (R28359) by Storr (1987b). Since the description of D. nasuta, R14800 has been disposed, date and reason of disposal unknown.

The registration number R13195 is associated with two specimens of D. nasuta; however, Kluge (1974) only refers to one specimen (R13195a). There are two specimens of $D$. nasuta bearing a dymo-printed registration tag with the number R13195; however, neither of them is suffixed with letter indicating which specimen is R13195a referred to by Kluge. It is suspected that Kluge was aware of the two specimens by his use of R13195a, and not just R13195; however, it is not clear which of the two specimens Kluge was referring to. The two dymo-printed registration tags are likely to have replaced original tags on the two specimens which whould have originally been lead tags with registration numbers hand punched that were used at the time of original registration. It is not known if the original lead tags were suffixed and the suffix was missed when replacement tags were attaced or if the addition of the suffix was the intention of Kluge to distinguish the two specimens and has never been included on the registration tags. As it is unclear which specimen was 
R13195a referred to by Kluge, both specimen bearing the registration tag R13195 are maintained as paratypes. To resolve the status of these specimens, one of the specimens has been reregistered as R175033. As the specimens are of similar size and condition and there is nothing to distinguish which specimen, if only one, Kluge was referring to as R13195a the reregistered specimen was selected at random.

Six additional paratypes are held in other collections: three at UMMZ (UMMZ 131206-07, 129999) and single specimens at AMNH (AMNH 102385), SAMA (SAMA R4513) and NMV (NMV D869).

\section{Delma pax Kluge, 1974}

Kluge, A.G. (1974) A taxonomic revision of the lizard family Pygopodidae. Miscellaneous Publications of the Museum of Zoology, University of Michigan 147: $1-221$ [113].

\section{Holotype}

R14804, 'Jones River, 21 miles [33.8 km] southeast of Roebourne, WA (20 $\left.58^{\prime} \mathrm{S}, 117^{\circ} 23^{\prime} \mathrm{E}\right)$ ', G.M. Storr, 21 May 1961.

\section{Paratypes (10)}

R13420，R13863, Mardie, WA; R14802-03, Mundabullangana, WA; R14805, Woodstock, WA; R17066, 9 mi [14.8 km] SE Mundabullangana, WA; R20069, Millstream, WA; R22629, Weeli Wolli Creek, WA; R22696, Turee Creek, WA; R28930, Mt Newman, WA.

\section{Remarks}

Four additional paratypes are held in other collections: three at SAMA (SAMA R3445a, R3452, R4514) and one at UMMZ (UMMZ 129889).

\section{Delma tealei Maryan, Aplin \& Adams, 2007}

Maryan, B., Aplin, K.P. and Adams, M. (2007) Two new species of the Delma tincta group (Squamata: Pygopodidae) from northwestern Australia. Records of the Western Australian Museum 23: 273-305 [284].

\section{Holotype}

R153811, 'Charles Knife Road, Cape Range, WA $\left(22^{\circ} 07^{\prime} 08^{\prime \prime} \mathrm{S}, 114^{\circ} 03^{\prime} 44^{\prime \prime} \mathrm{E}\right)$ ', B. Maryan and D. Algaba, 12 September 2003.

\section{Paratypes (7)}

R52934-35, R153819, Shothole Canyon, WA; R82532, 6 km W Exmouth, WA; R88548, 2 km E Yardie Creek mouth, WA; R102837, Cape Range NP, WA; R153813, 2 km S Yardie HS Caravan Park, WA.

\section{Remarks}

Liver sample of holotype and two paratypes (R153813, R153819) stored frozen $\left(-75^{\circ} \mathrm{C}\right)$ at WAM and EBU. Liver sample of one paratype (R102837) stored at EBU.

\section{Ophioseps repens Fry, 1914}

Fry, H.G. (1914) On a collection of reptiles and batrachians from Western Australia. Records of the Western Australian Museum 1: 174-210 [178].

\section{Holotype}

R364, 'Western Australia', collector unknown, accessioned September 1914 (Figure 6).

\section{Current nomenclature}

Aprasia repens, see Kluge (1974).

\section{Remarks}

Ophioseps repens was one of three species described by Fry based on material loaned to him for identification from the WAM collection of which no registration numbers and limited collection data were provided for type material (see the accounts of Diplodactylus woodwardi and Peropus variegatus punctatus (= Gehyra punctata) above). There is only one specimen of Aprasia repens within the collection with the broad locality of 'Western Australia' that would have been available to Fry at the time of description. A deteriorated handwritten tag attached to R364 states 'Ophioseps repens Fry', 'descry \& fig' and 'TYPE' with the locality of 'Western Australia' and faded initials of D. B. Fry (Figure 6). The specimen R364 was identified as the
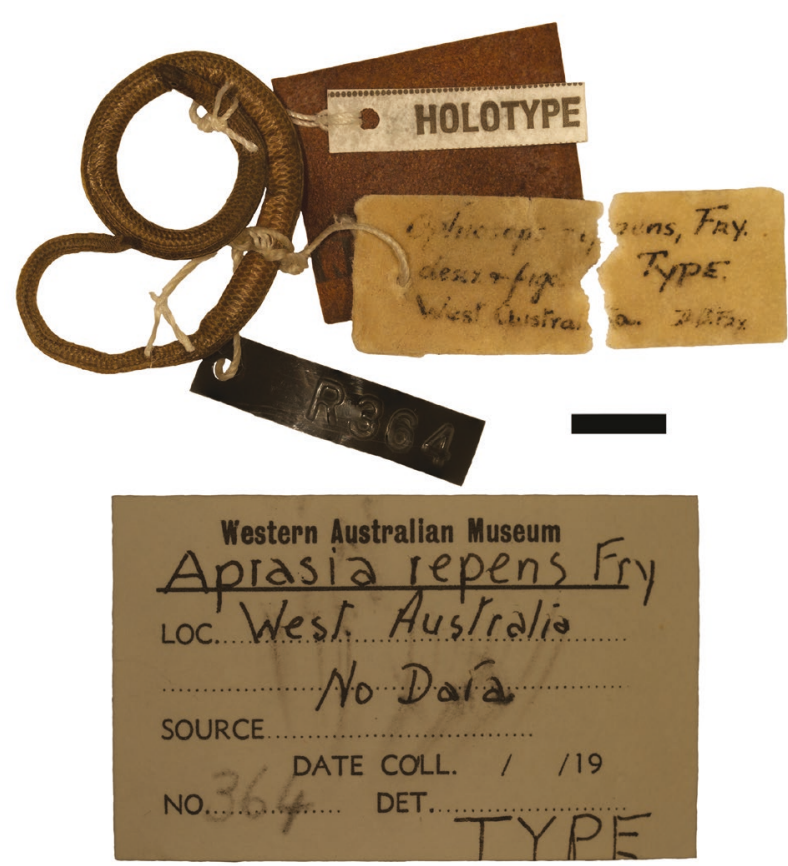

FIGURE 6 Ophioseps repens Fry, 1914 holotype (R364) and associated tags. Scale bar $=10 \mathrm{~mm}$. 
holotype in the WAM 1959-1960 Annual Report (Anonymous 1960) and repeated by Kluge (1974) and Cogger et al. (1983).

Kluge (1974, P. 64) stated 'In the absence of a specific type locality for repens (Fry, 1914), I take this opportunity to restrict it to the Swan View National Park, 35 $51^{\prime}$ S Lat, $116^{\circ} 03^{\prime}$ E Long, Western Australia' where the species was known to occur. Kluge's proposed type locality was subsequently repeated by Cogger et al. (1983); however, the restriction of type locality is not binding under the Code in the absence of any documented evidence from Kluge to justify his proposed change.

\section{Pletholax gracilis edelensis Storr, 1978}

Storr, G.M. (1978b) Taxonomic notes on the reptiles of the Shark Bay region, Western Australia. Records of the Western Australian Museum 6: 303-318 [304].

\section{Holotype}

R54627, '4 km S of Useless Loop [Shark Bay], WA $\left(26^{\circ} 10^{\prime} \mathrm{S}, 113^{\circ} 25^{\prime} \mathrm{E}\right)^{\prime}$, G. Harold and M. Peterson, 24 August 1976.

\section{Paratypes (4)}

R54755, 5 km S Useless Loop, WA; R54814, R54863, 4 km S Useless Loop, WA; R55085, 10 km NW Useless Loop, WA.

\section{ACKNOWLEDGEMENTS}

The authors would like to thank Glenn Shea (University of Sydney and AMS) for discussions regarding type material and the history of some species descriptions or authors, Laurie Smith and Ron Johnstone (WAM) for discussions regarding historic type specimens held at the WAM and assisting in identifying authors of entries and annotations in hardcopy WAM herpetology registers, Kenny Travouillon (WAM) for examining and photographing the type specimen of $P$. barbouri in the MNHN collection, Glenn Shea, Mark Hutchinson (SAMA) and Paul Oliver (Queensland Museum) for discussion regarding the identification, history and status of $P$. barbouri, Katie Smith Date (NMV) for examining and photographing the potential syntypes of Gehyra variegatus punctatus collected during the Horn Expedition in the NMV collection, Patrick Campbell (NHMUK) for providing additional information on the Nephrurus wheeleri paratype held at the NHMUK, and Ian Brennan (Australian National University) for technical discussions regarding pygopod species presented in this manuscript and providing unpublished molecular data that was used to recognise Delma haroldi as a junior synonym of D. butleri. AMB was supported by US National Science Foundation grant DEB 1555968.

\section{REFERENCES}

Angel, F. (1936). Deux gekkos nouveaux de Madagascar appartenant au genre Phyllodactylus. Bulletin de la Société Zoologique de France 61: 508-511.

Angel, F. (1942). Les lézards de Madagascar. Memoires de Academie Malgache 36: 1-139.

Anonymous. (1896, November 17). Donations to the Museum. The West Australian (New Series) Vol. 12(No. 3351): 3.

Anonymous. (1907a, July 19). Diseased camels. The Age No. 16334: 6.

Anonymous. (1907b, October 30). Port Hedland camels. The West Australian (New Series) Vol. 13(No. 6741): 10.

Anonymous. (1908, April 28). The Century camels. The West Australian (New Series) Vol. 14(No. 6894): 7.

Anonymous. (1960). Type specimens in the Western Australian Museum (Part 1). Western Australian Museum Annual Report 1959-60: 28-31.

Anonymous. (1961). Type specimens in the Western Australian Museum (Part 2). Western Australian Museum Annual Report 1960-61: 35-39.

Anonymous. (1963). Type specimens in the Western Australian Museum (Part 4). Western Australian Museum Annual Report 1962-63: 38-40.

Anonymous. (1964). Type specimens in the Western Australian Museum (Part 5). Western Australian Museum Annual Report 1963-64: 38-40.

Anonymous. (1966). Type specimens of the Western Australian Museum (Part 7). Western Australian Museum Annual Report 1965-66: 38-42.

Anonymous. (1968). Type specimens of the Western Australian Museum (Part 9). Western Australian Museum Annual Report 1967-68: 62-64.

Anonymous. (1970). Type specimens in the Western Australian Museum (discontinued in the Annual Report). Western Australian Museum Annual Report 1969-70: 44.

Aplin, K.P. and Adams, M. (1998). Morphological and genetic discrimitation of new species and subspecies of gekkonid and scincid lizards (Squamata: Lacertilia) from the Carnarvon Basin region of Western Australia. Journal of the Royal Society of Western Australia 81: 201-223.

Aplin, K.P. and Smith, L.A. (2001). Checklist of the frogs and reptiles of Western Australia. Records of the Western Australian Museum Supplement No. 63: 51-74.

Barbour, T. and Loveridge, A. (1946). First supplement to typical reptiles and amphibians. Bulletin of the Museum of Comparative Zoology 96: 59-214.

Bauer, A.M. and Doughty, P. (2012). A new bent-toed gecko (Squamata: Gekkonidae: Cyrtodactylus) from the Kimberley region, Western Australia. Zootaxa 3187: 32-42.

Bauer, A.M. and Henle, K. (1994). Das Tierreich Part 109: Familia Gekkonidae (Reptilia, Sauria). Part I Australia and Oceania. Verlag Walter de Gruyter Publishers, Berlin.

Bory de Saint-Vincent. (1823). Phyllure de Milius, Phyllurus milii. In, Audouin, [J.V.], Brongniart, A.[T.], Cambessèdes, [J.], de Candolle, [A.L.P.P.], Delafosse, G., Deshayes, [G.P.], [Loiseleur-]Deslon[g]champs, [J.L.A.], Drapiez, [P.A.J.], Edwards, [W.F.], Edwards, H.-M., Fée, A.[L.A.], SaintHilaire, G., Saint-Hilaire, I.G., Guérin[-Méneville], [F.E.], Guillemin, [A.], De Jussieu, A., Kunth, [C.S.], Latreille, [P.A.], Lesson, [R.P.], Prévost, [L.]C., Richard, [A.], Bory de Saint-Vincent [J.B.G.M.]. Dictionnaire classique d'Histoire naturelle. Vol. 17. Atlas et Illustration de Planches. Rey et Gravier, Paris. Plate CXX, Figure 1.

Boulenger, G.A. (1896). Descriptions of four new lizards from Roebuck Bay, N. W. Australia obtained by Dr. Dahl for the Christiania Museum. Annals and Magazine of Natural History (6)18: 232-235. 
Brennan, I.G., Bauer, A.M. and Jackman, T.R. (2016). Mitochondrial introgression via ancient hybridization, and systematics of the Australian endemic pygopodid gecko genus Delma. Molecular Phylogenetics and Evolution 94: 577-590.

Brygoo, É.-R. (1990). Les types de Gekkonidés (Reptiles, Sauriens) du Musum national d'Histoire naturelle, catalogue critique. Bulletin du Muséum National d'Histoire Naturelle, Paris (4)12(A)(3-4), supplement: 19-141.

Bustard, H.R. (1965a). The systematic status of the Australian geckos Gehyra variegata (Duméril and Bibron, 1836) and Gehyra australis Gray, 1845. Herpetologica 20: 259-272.

Bustard, H.R. (1965b). The systematic status of the Australian gecko, Gehyra variegata punctata (Fry). Herpetologica 21: $157-158$.

Bustard, H.R. (1969). Oedura reticulata, a new velvet gecko from south-west Western Australia. Western Australian Naturalist 11: 82-86.

Cleland, J.B. (1909). Notes on several birds found at Strelley River (Pt. Hedland, Marble Bar Road), N.W. Australia. Ети 8: 155-156.

Cogger, H.G. (1975). New lizards of the genus Pseudothecadactylus (Lacertilia: Gekkonidae) from Arnhem Land and northwestern Australia. Records of the Australian Museum 30: 87-97.

Cogger, H.G. (1979). Type specimens of reptiles and amphibians in the Australian Museum. Records of the Australian Museum 32: 163-210.

Cogger, H.G. (2000). Reptiles and Amphibians of Australia. $6^{\text {th }}$ edition. Reed New Holland, Sydney.

Cogger, H.G. (2014). Reptiles and Amphibians of Australia. $7^{\text {th }}$ edition. CSIRO Publishing, Collingwood.

Cogger, H.G., Cameron, E.E. and Cogger, H.M. (1983). Zoological Catalogue of Australia. Vol. 1. Amphibia and Reptilia. Australian Government Publishing Service, Canberra.

Couper, P.J. and Gregson, R.A.M. (1994). Redescription of Nephrurus asper Günther, and description of N. amyae sp. nov. and N. sheai sp. nov. Memoirs of the Queensland Museum 37: 67-81.

Doughty, P., Bauer, A.M., Pepper, M. and Keogh, J.S. (2018a) Spots before the eyes: revision of the saxicoline geckos of the Gehyra punctata (Squamata: Gekkonidae) species complex in the Pilbara region of Western Australia. Records of the Western Australian Museum 33(1): 1-50. doi: 10.18195/issn.0312-3162.33(1).2018.001-050

Doughty, P., Bourke G., Tedeschi, L.G., Pratt, R.C., Oliver, P.M., Palmer, R.A. and Moritz, C. (2018b). Species delimitation in the Gehyra nana (Squamata: Gekkoidae) complex: cryptic and divergent morphological evolution in the Australian Monsoonal Tropics, with the description of four new species. Zootaxa 4403: 201-244. doi: 10.11646/ zootaxa.4403.2.1

Doughty, P., Ellis, R.J. and Oliver, P.M. (2016). Many things come in small packages: revision of the clawless geckos (Crenadactylus; Diplodactylidae) of Australia. Zootaxa 4168: 239-278. doi: 10.11646/zootaxa.4168.2.2

Doughty, P. and Hutchinson, M.N. (2008). A new species of Lucasium (Squamata: Diplodactylidae) from the southern deserts of Western Australia and South Australia. Records of the Western Australian Museum 25: 95-106.

Doughty, P. and Oliver, P.M. (2011). A new species of Underwoodisaurus (Squamata: Gekkota: Carphodactylidae) from the Pilbara region of Western Australia. Zootaxa 3010: $20-30$.
Doughty, P. and Oliver, P.M. (2013). Systematics of Diplodactylus (Squamata: Diplodactylidae) from the southwestern Australian biodiversity hotspot: redefinition of D. polyopthalmus and the description of two new species. Records of the Western Australian Museum 28: 44-65.

Doughty, P., Oliver, P. and Adams, M. (2008). Systematics of stone geckos in the genus Diplodactylus (Reptilia: Diplodactylidae) from northwestern Australia, with a description of a new species from the Northwest Cape, Western Australia. Records of the Western Australian Museum 24: 247-265.

Doughty, P., Palmer, R., Sistrom, M.J., Bauer, A.M. and Donnellan, S.C. (2012). Two new species of Gehyra (Squamata: Gekkonidae) geckos from the north-west Kimberley region of Western Australia. Records of the Western Australian Museum 27: 117-134.

Doughty, P., Pepper, M. and Keogh, J.S. (2010). Morphological and molecular assessment of the Diplodactylus savagei species complex in the Pilbara region, Western Australia, with a description of a new species. Zootaxa 2393: 33-45.

Duméril, A.M.C. and Bibron, G. (1836). Erpétologie Générale ou Histoire Naturelle Complète des Reptiles. Vol. 3. Librairie Encyclopédique de Roret, Paris.

Duméril, A.M.C. and Duméril, A.H.A. (1851). Catalogue Méthodique de la Collection des Reptiles. Gide et Baudry, Paris.

Donnellan, S.C., Aplin, K.P. and Dempsey, P.J. (2000) Genetic and morphological variation in Australian Christinus (Squamata: Gekkonidae): preliminary overview with recognition of a cryptic species on the Nullabor Plain. Australian Journal of Zoology 48: 289-315. doi: 10.1071/ ZO98015

Ellis, R.J., Doughty, P. and Roberts, J.D. (2017). An annotated type catalogue of the frogs (Amphibia: Anura: Hylidae, Limnodynastidae, Myobatrachidae) in the collection of the Western Australian Museum. Records of the Western Australian Museum 32:1-28. doi: 10.18195/issn.03123162.32(1).2017.001-028

Ellis, R.J. and Georges, A. (2015). An annotated type catalogue of the turtles (Testudines: Pleurodira: Chelidae) in the collection of the Western Australian Museum. Records of the Western Australian Museum 30: 52-60. doi: 10.18195/ issn.0312-3162.30(1).2015.052-060

Fischer, J.G. (1882). Herpetologische Bemerkungen. II. Neue Eidechsen aus Australien und Polynesien. Archiv für Naturgeschichte 48: 286-302 + pl. XVI.

Fry, D.B. (1914). On a collection of reptiles and batrachians from Western Australia. Records of the Western Australian Museum and Art Gallery 1: 174-210.

Glauert, L. (1952). Herpetological miscellanea. I. Notes of some forms of Diplodactylus. Western Australian Naturalist 3: $166-168$.

Gray, J.E. (1832). Three new animals brought from New Holland by Mr Cunningham. Proceedings of the Committee of Science and Correspondance of the Zoological Society of London 1832: 39-40.

Greer, A.E. (1989). The Biology and Evolution of Australian Lizards. Surrey Beatty \& Sons, Chipping Norton.

Harvey, C. (1983). A new spcies of Nephrurus (Reptilia: Gekkonidae) from South Australia. Transactions of the Royal Society of South Australia 107: 231-235.

Hill, F.L. (1955). Notes on the natural history of the Monte Bello Islands. Proceedings of the Linnean Society of London 165 : 113-124. doi: 10.1111/j.1095-8312.1955.tb00724.x

Horner, P. (1999) Type specimens of terrestrial vertebrates in the Museum and Art Gallery of the Northern Territory - 
1973 to 1999. The Beagle, Records of the Museums and Art Galleries of the Northern Territory 15: 55-74.

Horner, P. (2005). Gehyra koira sp. nov. (Reptilia: Gekkonidae), a new species of lizard with two allopatric subspecies from the Ord-Victoria region of north-western Australia and a key to the Gehyra australis species complex. The Beagle, Records of the Museums and Art Galleries of the Northern Territory 21: 165-174.

Hutchinson, M.N., Doughty, P. and Oliver, P.M. (2009). Taxonomic revision of the stone geckos (Squamata: Diplodactylidae: Diplodactylus) of southern Australia. Zootaxa 2167: 25-46.

Hutchinson, M.N., Sistrom, M.J., Donnellan, S.C. and Hutchinson, R.G. (2014). Taxonomic revision of the Australian arid zone lizards Gehyra variegata and $G$. montium (Squamata, Gekkonidae) with description of three new species. Zootaxa 3814: 221-241. doi: 10.11646/ zootaxa.3814.2.4

International Commission on Zoological Nomenclature [ICZN]. (1999). International Code of Zoological Nomenclature. 4th edition. The International Trust for Zoological Nomenclature, London.

International Commission on Zoological Nomenclature [ICZN]. (2003). Declaration 44 - Amendment of Article 74.7.3. Bulletin of Zoological Nomenclature 60: 263.

International Commission on Zoological Nomenclature [ICZN]. (2012). Amendment of Articles 8, 9, 10, 21 and 78 of the International Code of Zoological Nomenclature to expand and refine methods of publication. ZooKeys 219: $1-10$.

James, B.H., Donnellan, S.C. and Hutchinson, M.N. (2001). Taxonomic revision of the Australian lizard Pygopus nigriceps (Squamata: Gekkonoidea). Records of the South Australian Museum 34: 37-52.

Jennings, W.B., Pianka, E.R. and Donnellan, S. (2003). Systematics of the lizard family Pygopodidae with implications for the diversification of Australian temperate biotas. Systematic Biology 52: 757-780.

Kealley, L., Doughty, P., Pepper, M., Keogh, S., Hillyer, M. and Huey, J. (2018) Conspicuously concealed: revision of the arid clade of the Gehyra variegata (Gekkonidae) species group in Western Australia using an integrative molecular and morphological approach, with the description of five cryptic species. PeerJ 6: e5334.

King, M. (1984a). A new species of Gehyra (Reptilia: Gekkonidae) from northern Western Australia. Transactions of the Royal Society of South Australia 108: $113-117$.

King, M. (1984b). Three new species of Oedura (Reptilia: Gekkonidae) from the Mitchell Plateau of north Western Australia. Amphibia-Reptilia 5: 329-337.

Kinghorn, J.R. (1926). A brief review of family Pygopodidae. Records of the Australian Museum 15: 40-64.

Kluge, A.G. (1962a). A new species of gekkonid lizard, genus Diplodactylus (Gray), from the southern interior of Western Australia. Western Australian Naturalist 8: 97-101.

Kluge, A.G. (1962b). A new species of gekkonid lizard, genus Diplodactylus, from the Carnarvon region, Western Australia. Western Australian Naturalist 8: 73-75.

Kluge, A.G. (1963a). Three new species of the gekkonid lizard genus Diplodactylus Gray from Australia. Records of the Australian Museum 14: 545-553

Kluge, A.G. (1963b). A review of the gekkonid lizard genus Heteronota Gray, with a description of a new species from Western Australia. Journal of the Royal Society of Western Australia 46: 63-67.
Kluge, A.G. (1965). The systematic status of certain Australian lizards of the family Gekkonidae. Australian Zoologist 13: 121-125.

Kluge, A.G. (1967). Systematics, phylogeny, and zoogeography of the lizard genus Diplodactylus Gray (Gekkonidae). Australian Journal of Zoology 15: 10071108.

Kluge, A.G. (1974). A taxonomic revision of the lizard family Pygopodidae. Miscellaneous Publications, Museum of Zoology, University of Michigan 147: 1-221.

Kluge, A.G. (1976). Phylogenetic relationships in the lizard family Pygopodidae: an evaluation of theory, methods and data. Miscellaneous Publications, Museum of Zoology, University of Michigan 152: 1-72.

Kluge, A.G. (1984) Type-specimens of reptiles in the University of Michigan Museum of Zoology. Miscellaneous Publications, Museum of Zoology, University of Michigan 167: 1-84.

Loveridge, A. (1932). New lizards of the genera Nephrurus and Amphibolurus from Western Australia. Proceedings of the New England Zoological Club 13: 31-34.

Lucas, A.H.S. and Frost, C. (1896). Reptilia. In: Spencer, W. B. (ed.) Report on the work of the Horn Scientific Expedition to Central Australia. Part II. - Zoology. Dulau and Co., London and Melville, Mullen and Slade, Melbourne, pp. 112-175 + pl. VIII-XII.

Maryan, B., Aplin, K.P. and Adams, M. (2007). Two new species of the Delma tincta group (Squamata: Pygopodidae) from northwestern Australia. Records of the Western Australian Museum 23: 273-305.

Maryan, B., Adams, M. and Aplin, K.P. (2015a). Taxonomic resolution of the Aprasia repens speciesgroup (Squamata: Pygopodidae) from the Geraldton Sandplains: a description of a new species and additional mainland records of $A$. clairae. Records of the Western Australian Museum 30: 12-32. doi: 10.18195/issn.03123162.30(1).2015.012-032

Maryan, B., Brennan, I.G., Adams, M. and Aplin, K.P. (2015b). Molecular and morphological assessment of Delma australis Kluge (Squamata: Pygopodidae), with a description of a new species from the biodiversity 'hotspot' of southwestern Western Australia. Zootaxa 3946: 301-330. doi: 10.11646/zootaxa.3946.3.1

Maryan, B., Bush, B.G. and Adams, M. (2013a). Morphological and molecular assessment of Aprasia fusca and $A$. rostrata (Squamata: Pygopodidae), with a description of a new species from the Lake MacLeod region, Western Australia. Records of the Western Australian Museum 28: 144-163.

Maryan, B., How, R.A. and Adams, M. (2013b). A new species of the Aprasia repens species-group (Squamata: Pygopodidae) from Western Australia. Records of the Western Australian Museum 28: 30-43.

Mitchell, F.J. (1965). Australian geckos assigned to the genus Gehyra Gray (Reptilia, Gekkonidae). Senckenbergiana Biologica 46: 287-319.

Oliver, P. and Bauer, A.M. (2011). Systematics and evolution of the Australian knob-tail geckos (Nephrurus, Carphodactylidae, Gekkota): Plesiomorphic grades and biome shifts through the Miocene. Molecular Phylogenetics and Evolution 59: 664-674. doi: 10.1016/j. ympev.2011.03.018

Oliver, P., Bauer, A.M., Greenbaum, E., Jackman, T. and Hobbie, T. (2012). Molecular phylogenetics of the arboreal Australian gecko genus Oedura Gray 1842 (Gekkota: Diplodactylidae): Another plesiomorphic grade? 
Molecular Phylogenetics and Evolution 63: 255-264. doi: 10.1016/j.ympev.2011.12.013

Oliver, P.M., Bourke, G., Pratt, R.C., Doughty, P. and Moritz, C. (2016). Systematics of small Gehyra (Squamata: Gekkonidae) of the southern Kimberley, Western Australia: redescription of G. kimberleyi Börner \& Schüttler, 1983 and description of a new restricted range species. Zootaxa 4107: 49-64. doi: 10.11646/ zootaxa.4107.1.2

Oliver, P.M., Couper, P.J. and Pepper, M. (2014a). Independent transitions between monsoonal and arid biomes revealed by systematic revision of a complex of Australian geckos (Diplodactylus: Diplodactylidae). PLoS ONE 9: el11895. doi: 10.1371/journal.pone.0111895

Oliver, P.M. and Doughty, P. (2016). Systematic revision of the marbled velvet geckos (Oedura marmorata species complex, Diplodactylidae) from the Australian arid and semi-arid zones. Zootaxa 4088: 151-176. doi: 10.11646/ zootaxa.4088.2.1

Oliver, P.M., Hutchinson, M.N. and Cooper, S.J.B. (2007). Phylogenetic relationships in the lizard genus Diplodactylus Gray and resurrection of Lucasium Wermuth (Gekkota, Diplodactylidae). Australian Journal of Zoology 55: 197-210. doi: 10.1071/ZO07008

Oliver, P.M., Laver, R.J., Melville, J. and Doughty, P. (2014b). A new species of velvet gecko (Oedura: Diplodactylidae) from the limestone ranges of the southern Kimberley, Western Australia. Zootaxa 3873: 49-61. doi: 10.11646/ zootaxa.3873.1.4

Parker, H.W. (1956). The lizard genus Aprasia; its taxonomy and temperature-correlated variation. Bulletin of the British Museum (Natural History) 3: 365-385.

Pepper, M., Doughty, P., Hutchinson, M.N. and Keogh, J.S. (2011). Ancient drainages divide cryptic species in Australia's arid zone: morphological and multigene evidence for four new species of Beaked Geckos (Rhynchoedura). Molecular Phylogenetics and Evolution 61: 810-822. doi: 10.1016/j.ympev.2011.08.012

Pepper, M., Doughty, P., Fujita, M.K., Moritz, C. and Keogh, J.S. (2013). Speciation on the rocks: integrated systematics of the Heteronotia spelea species complex (Gekkota; Reptilia) from Western and central Australia. PLoS ONE 8: e78110. doi: 10.1371/journal.pone.0078110

Pepper, M., Doughty, P. and Keogh, J.S. (2006). Molecular phylogeny and phylogeography of the Australian Diplodactylus stenodactylus (Gekkota; Reptilia) speciesgroup based on mitochondrial and nuclear genes reveals an ancient split between Pilbara and non-Pilbara $D$. stenodactylus. Molecular Phylogenetics and Evolution 41: 539-555. doi: 10.1016/j.ympev.2006.05.028

Péron, F. (1807). Voyage de Découvertes Aux Terres Australes, exécuté par ordre de Sa Majesté l'Empereur et Roi, Sur les Corvettes le Géographe, le Naturaliste, et la Goelette le Casuarina, Pendant les Années 1800, 1801, 1802, 1803 et 1804. Imprimerie Impériale, Paris.

Peters, W.C.H. (1863). Übersicht der von Hrn. Richard Schomburgk an das zoologische Museum eingesandten Amphibien, aus Buchsfelde bei Adelaide in Südaustralien. Monatsberichte der königlichen Akademie der Wissenschaften zu Berlin 1863: 228-236.

Sabaj Pérez, M.H. (2016). Standard symbolic codes for institutional resource collections in herpetology and ichthyology: an online reference. Version 6.5 (16 August 2016). American Society of Ichthyologists and
Herpetologists, Washington, DC. Available at: http://www. asih.org/

Schlüter, A. and Hallermann, J. (1997). The type specimens in the herpetological collection of the Staatliches Museum für Naturkunde in Stuttgart. Stuttgarter Beiträge zur Naturkunde Series A (Biologie) 553: 1-15.

Shea, G.M. (1991). Revisionary notes on the genus Delma (Squamata: Pygopodidae) in South Australia and the Northern Territory. Records of the South Australian Museum 25: 71-90.

Shea, G.M. (2002). The identity of Phyllurus milii Bory de Saint Vincent, 1823 (Squamata: Pygopodidae: Diplodactylidae). Records of the Australian Museum 20: 431-435.

Shea, G.M. and Sadlier, R.A. (1999). A catalogue of the non-fossil amphibian and reptile type specimens in the collection of the Australian Museum: types currently, previously and purportedly present. Technical Reports of the Australian Museum 15: 1-92.

Smith, L.A. (1989). Taxonomic status of the gecko Pseudothecadactylus lindneri cavaticus Cogger. Records of the Western Australian Museum 14: 425-426.

Smith, L.A. (1995). A new Diplodactylus, subgenus Strophurus (Lacertilia: Gekkonidae) from northern Australia. Records of the Western Australian Museum 17: 351-353.

Smith, L.A. and Henry, J. (1999). Aprasia picturata (Squamata: Pygopodidae), a new legless lizard from the interior of Western Australia. Journal of the Royal Society of Western Australia 82: 75-77.

Storr, G.M. (1963). The gekkonid genus Nephrurus in Western Australia, including a new species and three new subspecies. Journal of the Royal Society of Western Australia 46: 85-90.

Storr, G.M. (1968). Nephrurus stellatus, A new knob-tailed gecko from southern Australia. Western Australian Naturalist 10: 180-182.

Storr, G.M. (1970). Aprasia smithi, a new worm-lizard (Pygopodidae) from Western Australia. Western Australian Naturalist 11: 141.

Storr, G.M. (1978a). Seven new gekkonid lizards from Western Australia. Records of the Western Australian Museum 8: 337-352.

Storr, G.M. (1978b). Taxonomic notes on the reptiles of the Shark Bay region, Western Australia. Records of the Western Australian Museum 6: 303-318.

Storr, G.M. (1979a). The Diplodactylus vittatus complex (Lacertilia, Gekkonidae) in Western Australia. Records of the Western Australian Museum 7: 391-402.

Storr, G.M. (1979b). Five new lizards from Western Australia. Records of the Western Australian Museum 8: 134-142.

Storr, G.M. (1982). Two new Gehyra (Lacertilia: Gekkonidae) from Australia. Records of the Western Australian Museum 10: 53-59.

Storr, G.M. (1983). Two new lizards from Western Australia (genera Diplodactylus and Lerista). Records of the Western Australian Museum 11: 59-62.

Storr, G.M. (1987a). The genus Phyllodactylus (Lacertilia: Gekkonidae) in Western Australia. Records of the Western Australian Museum 13: 275-284.

Storr, G.M. (1987b). Three new legless lizards (Pygopodidae) from Western Australia. Records of the Western Australian Museum 13: 345-355. 
Storr, G.M. (1988a). A new species of Diplodactylus (Lacertilia: Gekkonidae) from northwestern Australia. Records of the Western Australian Museum 14: 183-187.

Storr, G.M. (1988b). Three new Diplodactylus (Lacertilia: Gekkonidae) from the arid zone of Australia. Records of the Western Australian Museum 14: 217-223.

Storr, G.M. (1988c). The subspecies of Diplodactylus spinigerus (Lacertilia: Gekkonidae). Records of the Western Australian Museum 14: 177-182.

Storr, G.M. (1988d). The Diplodactylus ciliaris complex (Lacertilia: Gekkonidae) in Western Australia. Records of the Western Australian Museum 14: 121-188.

Storr, G.M. (1989). A new Heteronotia (Lacertilia: Gekkonidae) from Western Australia. Records of the Western Australian Museum 14: 269-273.
Storr, G.M., Smith, L.A. and Johnstone, R.E. (1990). Lizards of Western Australia III: Geckos and Pygopods. Western Australian Museum, Perth.

Wells, R.W. and Wellington, C.R. (1984) A synopsis of the class Reptilia in Australia. Australian Journal of Herpetology 1: 73-129.

Wermuth, H. (1965) Liste der rezenten Amphibien und Reptilien: Gekkonidae, Pygopodidae, Xantusiidae. Das Tierreich 80: xxii +246 .

Wilson, S. and Swan, G. (2003). A Complete Guide to Reptiles of Australia. Reed New Holland, French's Forest.

Wilson, S. and Swan, G. (2017). A Complete Guide to Reptiles of Australia. 5th edition. Reed New Holland Publishers, Sydney.

MANUSCRIPT RECEIVED 13 APRIL 2017; ACCEPTED 7 JUNE 2018. 